University of Nebraska - Lincoln

DigitalCommons@University of Nebraska - Lincoln

U.S. Environmental Protection Agency Papers

U.S. Environmental Protection Agency

2008

\title{
Altered gene expression in the brain and liver of female fathead minnows Pimephales promelas Rafinesque exposed to fadrozole
}

D. L. Villeneuve

U.S. EPA

I. Knoebl

U.S. EPA

P. Larkin

Sante Fe Community College

A. L. Miracle

Pacific Northwest Laboratory

B. J. Carter

EcoArray

See next page for additional authors

Follow this and additional works at: https://digitalcommons.unl.edu/usepapapers

Villeneuve, D. L.; Knoebl, I.; Larkin, P.; Miracle, A. L.; Carter, B. J.; Denslow, N. D.; and Ankley, G. T., "Altered gene expression in the brain and liver of female fathead minnows Pimephales promelas Rafinesque exposed to fadrozole" (2008). U.S. Environmental Protection Agency Papers. 183.

https://digitalcommons.unl.edu/usepapapers/183

This Article is brought to you for free and open access by the U.S. Environmental Protection Agency at DigitalCommons@University of Nebraska - Lincoln. It has been accepted for inclusion in U.S. Environmental Protection Agency Papers by an authorized administrator of DigitalCommons@University of Nebraska - Lincoln. 


\section{Authors}

D. L. Villeneuve, I. Knoebl, P. Larkin, A. L. Miracle, B. J. Carter, N. D. Denslow, and G. T. Ankley 


\title{
Altered gene expression in the brain and liver of female fathead minnows Pimephales promelas Rafinesque exposed to fadrozole
}

\author{
D. L. Villeneuve*†, I. Knoebl $\$$, P. Larkin§ $₫$, A. L. Miracle $\|$, \\ B. J. Carter 1, N. D. Denslow\# and G. T. Ankley* \\ *US EPA, ORD, NHEERL, Mid-Continent Ecology Division, 6201 Congdon Blvd, \\ Duluth, MN 55804, U.S.A., †US EPA, ORD, NERL, Ecological Exposure Research \\ Division, 26 West Martin Luther King Drive, Cincinnati, OH 45268, U.S.A., §Santa Fe \\ Community College, 3000 Northwest 83rd Street, Gainesville, FL 32606, U.S.A., ||Pacific \\ Northwest National Laboratory, P. O. Box 999, MSID K3-61, Richland, WA 99352, \\ U.S.A., IEcoArray, 12085 Research Drive, Alachua, FL 32615, U.S.A. and \#Department \\ of Physiological Sciences and Center for Environmental and Human Toxicology, \\ University of Florida, P. O. Box 110885, Gainesville, FL 32611, U.S.A.
}

The fathead minnow Pimephales promelas is a small fish species widely used for ecotoxicology research and regulatory testing in North America. This study used a 2000 gene oligonucleotide microarray to evaluate the effects of the aromatase inhibitor, fadrozole, on gene expression in the liver and brain tissue of exposed females. Reproductive measures, plasma vitellogenin and gene expression data for the brain isoform of aromatase (cytP19B), vitellogenin precursors and transferrin provided evidence supporting the efficacy of the fadrozole exposure. Unsupervised analysis of the microarray results identified 20 genes in brain and 41 in liver as significantly up-regulated and seven genes in brain and around 45 in liver as significantly down-regulated. Differentially expressed genes were associated with a broad spectrum of biological functions, many with no obvious relationship to aromatase inhibition. However, in brain, fadrozole exposure elicited significant up-regulation of several genes involved in the cholesterol synthesis, suggesting it as a potentially affected pathway. Gene ontologybased analysis of expression changes in liver suggested overall down-regulation of protein biosynthesis. While real-time polymerase chain reaction analyses supported some of the microarray responses, others could not be verified. Overall, results of this study provide a foundation for developing novel hypotheses regarding the system-wide effects of fadrozole, and other chemical stressors with similar modes of action, on fish biology.

Journal compilation (C) 2008 The Fisheries Society of the British Isles No claim to original US government works

Key words: aromatase inhibitor; cholesterol; endocrine disruption; fish; transcriptomics; vitellogenin.

\section{INTRODUCTION}

The fathead minnow Pimephales promelas Rafinesque, 1820, is an animal model widely used in aquatic ecotoxicology research and regulatory programmes in North America (Ankley \& Villeneuve, 2006). Over the years, the field of aquatic toxicology and associated regulatory needs have gradually evolved from a focus on

†Author to whom correspondence should be addressed. Tel.: +1 218529 5217; fax: +1 218529 5003; email: villeneuve.dan@epa.gov 
overt toxicity to concerns over more subtle impacts on reproduction, development, immune function, behaviour and, or other critical functions of fish and wildlife within their ecosystems. This shift in focus has evoked changes in the tools being used to conduct ecotoxicology research. There is increasing reliance on molecular and biochemical analyses as a foundation for determining or predicting potential mode(s) of action of unknown or poorly characterized chemicals. Additionally, there is increasing need to understand the ways biological systems respond to stressors to improve the ability to predict ecologically relevant outcomes and risks based on chemical mode of action. Transcriptomic analyses with high-density oligonucleotide microarrays represent a research tool that can be applied to help address some of the critical research needs and challenges facing the fields of ecotoxicology and ecological risk assessment.

To facilitate the widespread use of transcriptomic data to support research and regulation, there is a need to develop commercially available, high-density, general purpose, oligonucleotide microarrays for common ecotoxicity test organisms with rich historical databases of regulatory toxicity data, such as the fathead minnow (Ankley \& Villeneuve, 2006; Ankley et al., 2006). In 2004, the US Environmental Protection Agency (EPA) initiated a cooperative research and development agreement with EcoArray (Alachua, FL, U.S.A.) aimed at addressing this need. Larkin et al. (2007) reported on the initial validation of a 2000 gene fathead minnow microarray. In that study, fathead minnows were exposed to $17 \beta$-oestradiol, and gene expression profiles in the livers of males were examined using the microarray (Larkin et al., 2007). Gene expression responses observed in the study were generally consistent with those observed in previous cDNA macroarray studies with largemouth bass Micropterus salmoides (Lacepède, 1802) (Larkin et al., 2002) and sheepshead minnow Cyprinodon variegatus Lacepède, 1803 (Larkin et al., 2003; Knoebl et al., 2006) and in oligonucleotide microarray studies with Japanese medaka Oryzias latipes (Temminck \& Schlegel, 1846) (Kishi et al., 2006).

The present study was designed to complement the initial validation of the 2000 gene fathead minnow microarray by using it to examine transcript changes in fathead minnows exposed to the aromatase inhibitor, fadrozole. Aromatase is a cytochrome $\mathrm{P} 450$ enzyme that catalyses the critical reaction that converts $\mathrm{C} 19$ androgens (e.g. testosterone and androstenedione) to C18 oestrogens (e.g. 17 $\beta$-oestradiol and oestrone). The reaction catalysed by aromatase is thought to be the rate-limiting step in oestrogen biosynthesis (Simpson et al., 1994). As far as is known, this is the first microarray study with a fish species that has examined the effects of an aromatase inhibitor on gene expression. Villeneuve et al. (2007) previously reported a limited analysis of the microarray results as a demonstration of the utility of graphical systems models for conducting hypothesis-driven ecotoxicogenomics research. However, in addition to their utility for systems-oriented hypothesis-based investigation, microarrays are also ideally suited for conducting unsupervised analyses (Ankley et al., 2006). Because they can be used effectively to screen expression of thousands of different genes without a priori knowledge of which may be affected, microarrays are well suited for discovery and hypothesis generation. Unsupervised microarray analyses have considerable potential for use in field monitoring and, or exposure assessment as a means to identify the types of stressors to 
which organisms are being exposed (Ankley et al., 2006). Furthermore, in screening unknown or poorly characterized chemicals, unsupervised analyses may be useful for identifying unsuspected modes of action (Ankley et al., 2006).

This study focused on the use of an unsupervised analysis to identify novel genes that may be differentially expressed as a result of the direct or indirect effects of fadrozole on the brain and livers of exposed female fathead minnows. Effects of fadrozole on plasma vitellogenin concentrations and reproductive output were examined to help establish efficacy of fadrozole in the experiment and provide some phenotypic anchoring of the transcript-level responses. Additionally, quantitative real-time polymerase chain reaction (QPCR) assays were used to evaluate selected microarray responses and follow up on several hypotheses derived from the microarray analysis. Overall, results of this study provided both novel information regarding the molecular response of fathead minnows to an aromatase inhibitor and further evaluation of the 2000 gene microarray, which helped inform the subsequent development of a 22000 gene microarray for the fathead minnow (http://www.ecoarray.com).

\section{METHODS}

\section{FADROZOLE EXPOSURE}

Fadrozole was provided by Novartis, Inc. (purity $\geq 99 \%$; Dr H. Cooper Eckhardt, Summit, NJ, U.S.A.). Adult (c. 6 month old) male $(4.65 \pm 0.93 \mathrm{~g})$ and female $(1.90 \pm$ $0.44 \mathrm{~g}$ ) fathead minnows obtained from an on-site aquatic culture unit at the US EPA Mid-Continent Ecology Division were paired and placed in tanks with a breeding substrate and allowed to acclimate to exposure-like conditions $\left(25^{\circ} \mathrm{C}, 16: 8 \mathrm{~h}\right.$ light:dark photoperiod, fed adult brine shrimp twice daily) over a period of at least 1 week. Exposures were initiated by transferring randomly selected pairs (one male and one female) to exposure tanks supplied with a continuous flow-through of Lake Superior water containing measured concentrations of $0(<2 \cdot 0), 6$ and $60 \mu \mathrm{g} 1^{-1}$ fadrozole (Villeneuve et al., 2007; supporting information SI-5) delivered without the use of a carrier solvent. There were four replicate tanks per treatment with two pairs of fish (separated by a mesh divider) per tank. Spawning activity and fecundity (number of eggs) were monitored daily. After separate exposures, either $24 \mathrm{~h}( \pm 90 \mathrm{~min})$ or 7 days $( \pm 4 \mathrm{~h})$ in duration, fish were humanely euthanized in buffered tricaine methanesulphonate (Finquel; Argent, Redmond, WA, U.S.A.). Plasma, liver, gonad and brain samples were then collected and tissue samples transferred directly to pre-weighed vials containing RNAlater ${ }^{\circledR}$ (Sigma, St Louis, MO, U.S.A.). Plasma samples were stored frozen at $-80^{\circ} \mathrm{C}$. Vitellogenin concentrations in the plasma of individual females from all treatments were quantified by enzyme-linked immunosorbent assay with a fathead minnow polyclonal antibody (Korte et al., 2000; US EPA, 2002). Average water quality characteristics $( \pm$ S.D. $)$ monitored over the course of the $24 \mathrm{~h}$ and 7 days experiments, respectively, were temperature $25 \cdot 1 \pm 0 \cdot 3$ and $25 \cdot 5 \pm 0 \cdot 1^{\circ} \mathrm{C}, \mathrm{pH} 7 \cdot 39 \pm 0 \cdot 17$ and $7 \cdot 21 \pm 0 \cdot 04$ and dissolved oxygen $5.15 \pm 0.60$ and $5.74 \pm 0.52 \mathrm{mg} \mathrm{l}^{-1}$. All laboratory procedures involving the animals were reviewed and approved by the local Animal Care and Use Committee in compliance with Animal Welfare Act regulations and Interagency Research Animal Committee guidelines.

\section{MICROARRAY ANALYSIS}

Expression of c. 2000 genes in the whole liver and brain of female fathead minnows exposed to $60 \mu \mathrm{g}^{-1}$ fadrozole or Lake Superior water (control) for 7 days was analysed with the fathead minnow microarray validated and described by Larkin et al. 
(2007; gene expression omnibus (GEO) accession no. GPL6516). Briefly, a variety of fathead minnow cDNA and suppression subtractive hybridization libraries from multiple tissues including gonad, liver, brain, heart and spleen from both male and female fathead minnows were constructed and clones sequenced (Larkin et al., 2007). In total, the sequencing efforts yielded c. 2000 unique genes that were positively matched (e value $<1 \mathrm{E}-5)$ with clones found in the National Center for Biotechnology Information (NCBI) non-redundant or nucleotide database (Larkin et al., 2007). Probes for each gene were designed using Agilent software (Agilent Technologies, Palo Alto, CA, U.S.A.), and 60-mer oligonucleotides were synthesized in situ on treated glass slides using inkjet deposition technology (Larkin et al., 2007). Each unique probe spotted on the array was assigned an identification number (EA_Pp_\#\#\#) and annotated with the following information: target sequence name; query sequence name; a gene name derived from the highest confidence match in the non-redundant (NR) or nucleotide (NT) database (NCBI); biological process, cellular component and molecular function gene ontology (GO) terms (where available; Gene Ontology Consortium, 2006); the top basic local alignment search tool (BLAST) hit from the NR database along with accession number and e value; and the top BLAST hit from the NT database along with its accession number and e value. Approximately $90 \%$ of the sequences were annotated with a name corresponding to a BLAST hit in the NT or NR database and biological process, cellular component and molecular function GO annotations were available for 51,37 and $62 \%$ of the sequences, respectively. Duplicates of all probes were spotted at random locations on the slide surface, and in cases where the direction of a gene could not be determined, probes were synthesized from both the strands (forward and reverse complement; Larkin et al., 2007). For selected genes (e.g. vitellogenin), multiple probes spanning different portions of the gene sequence or designed based on different target sequences for the gene were synthesized on the microarray. This multiple spotting approach took advantage of the extra capacity of the microarray format (i.e. 11000 features, including Agilent platform control spots, two arrays per glass slide) to examine whether there were significant differences in probe performance (Larkin et al., 2007).

Total RNA was isolated from tissue samples using TRI reagent lysis solution (Molecular Research Center, Cincinnati, OH, U.S.A.) following the manufacturer's protocol. Samples were DNAse treated and quality of the total RNA was evaluated by denaturing agarose gel electrophoresis and optical density (260/280 ratio $1 \cdot 8-2 \cdot 0)$. Aliquots of total RNA extracted from the liver or brain of two females from the same replicate tank were pooled, and poly-A RNA was reverse transcribed from $500 \mathrm{ng}$ of pooled total RNA using a poly-dT-T7 primer and then cRNA was labelled with cyanine 5 (experimental samples) or cyanine 3 (reference) using Agilent's low-input fluorescent linear amplification kit (for additional details see Larkin et al., 2007). Amplification yields and dye incorporation were quantified using a Nanodrop spectrophotometer (Agilent). Three replicate-pooled samples (cyanine 5 labelled), per treatment, per tissue, were then hybridized to the 2000 gene microarrays along with reference samples labelled with cyanine 3 (Larkin et al., 2007), following the manufacturer's recommended protocol (Agilent; 60-mer oligo microarray processing protocol). The same reference sample, consisting of pooled liver, brain and gonad samples from adult male and female fathead minnows, was used for all analyses (aliquots from a single labelling reaction stored at $-80^{\circ} \mathrm{C}$ until used).

The slides were scanned with an Agilent DNA microarray scanner and raw images processed using Agilent's Feature Extraction software. Resulting data were analysed using the AnalyzeIt statistical package (University of Florida, Gainesville, FL, U.S.A.). Data were first filtered to remove flagged features (e.g. saturated, non-uniform spots). Following filtering, data from each spot were local background subtracted, Lowess normalized and $\log _{10}$ transformed. The mean response for each probe (spot) across chips ( $n=3$ for each tissue-treatment) was determined, and a $t$-test performed to estimate the statistical significance of differences between the control and $60 \mu \mathrm{g} \mathrm{l^{-1 }}$ fadrozole treatment group. Probes were ranked in ascending order based on $P$-value (i.e. those responses with the lowest probability of being a false positive to those with the greatest probability) and then two quantitative decision criteria were applied to 
identify putative differentially expressed genes while minimizing the reporting of false positives. First, in all cases where a duplicate (same oligonucleotide sequence) probe was spotted on the microarray (and data were not removed by filters), fold change and $t$-test $P$-values of the duplicate probes were compared as means to assess the reliability of the response. Any duplicate probes with contradictory fold-change data (i.e. one duplicate probe up-regulated and one down-regulated) or with average $P$-values $>0.05$ were considered unreliable and not included in the list of differentially expressed genes. In the case of brain, this criterion narrowed the list of differentially expressed genes to a relative handful; consequently, no additional criterion was applied, except in cases where a duplicate probe response could not be identified. In the case of liver, the list was narrowed further by applying a Benjamini and Hochberg false discovery rate (FDR) multiple test correction (Benjamini \& Hochberg, 1995) to ranked $P$-values for individual probes. FDR $=0 \cdot 1$ was assigned as a cut off value and applied such that only genes with an average uncorrected $P$-value $<0.05$ among duplicate probes and a Benjamini and Hochberg corrected $P$-value $<0 \cdot 1$, for at least one of the two duplicate probes, were included on the list of differentially expressed genes. In cases where comparison to a duplicate probe response was not feasible (generally because of data being flagged and removed by filters), only probes meeting the FDR $<0 \cdot 1$ criterion were included.

\section{GENE ONTOLOGY-BASED ANALYSIS}

Annotation of the 2000 gene microarray provided by EcoArray was loaded into GeneSpring GX 7.3.1 software (Agilent Technologies) as a custom genome, and annotations were updated based on NT accession numbers using the Genespider function. 'Enriched' biological process GO categories associated with genes differentially expressed in this study were identified using a hypergeometric test without multiple testing correction (GeneSpring GX 7.3.1, Gene Ontology Browser). For the purposes of this study, statistical enrichment was defined as hypergeometric $P<0.01$ with at least three differentially expressed genes in the category. GO-based analysis was performed using both the moderately conservative lists of differentially expressed genes identified using the criteria described above and the expanded lists based on relaxed statistical criteria (i.e. $P<0.05$ for a single probe and no conflicting fold-change data for duplicate or multiple probes; non-redundant by gene name; see Appendices 4, 5 and 6). While the relaxed criteria allows for more false positives to be identified as differentially expressed, it was considered suitable for GO analysis that considers profiles of multiple genes with similar function, rather than any one specific gene. Furthermore, the additional gene representation on the relaxed list provided a means to assess the robustness of conclusions based on more restricted lists, which place greater weight on individual responses.

\section{QUANTITATIVE REAL-TIME PCR}

QPCR was used to assess relative expression of fathead minnow genes coding for transferrin, cytochrome P450 51 (cytP51; EC 1.14.13.70), pre-proguanylin (PPG), fibroin-like substance (FLS), vitellogenin, steroidogenic acute regulatory protein (StAR) and sterol response element binding protein 2 (SREBP-2). The intent of the QPCR analyses was to evaluate-validate selected microarray responses (in the case of transferrin, cytP51, PPG, FLS and vitellogenin) or investigate specific hypotheses (in the case of StAR and SREBP-2). In addition, QPCR was used to assess gene expression responses in the liver of female fathead minnows at the additional concentration $\left(6 \mu \mathrm{g}^{-1}\right)$ and time-point $(24 \mathrm{~h})$ tested. Total RNA was isolated from whole liver or brain tissue of individual females as described for the microarray analysis (Larkin et al., 2007). In the case of females from the 7 days control and $60 \mu \mathrm{g}{ }^{-1}$ fadrozole treatments, the total RNA samples used for QPCR were aliquots of the same total RNA samples analysed by microarray but neither pooled nor cyanine 5 labelled. Gene-specific primers were 
designed based on partial cDNA sequences (StAR and transferrin) or expressed sequence tags (ESTs) available in GenBank (Table I) using PrimerExpress software (Applied Biosystems, Foster City, CA, U.S.A.). ESTs corresponding to fathead minnow genes of interest were identified by nucleotide-nucleotide BLAST (BLASTn) search of the $P$. promelas EST database using the top NT database hits from the microarray annotation as a query sequence (Table I). In the case of SREBP-2, which was not represented on the microarray, the amino acid sequence for pufferfish Tetraodon nigroviridis Marion de Procé, 1822; CAG01649), which had significant homology to mouse SREBP-2 (AAK54763), was used as a query sequence in a translated BLASTn search of the P. promelas EST database (Table I). Amplification of 18S ribosomal RNA (18S) sequences for normalization was performed using QuantumRNA Universal 18S Primer Mix (Ambion, Austin, TX, U.S.A.). Total RNA from the samples was reverse transcribed with $50 \mu \mathrm{M}$ random hexamers and $50 \mu \mathrm{M}$ oligo $\mathrm{d}(\mathrm{T})_{23} \mathrm{VN}$, using reverse transcriptase reagents and the protocol recommended by Applied Biosystems. QPCR reactions were carried out in duplicate in a $20 \mu \mathrm{l}$ reaction volume consisting of $10 \mu \mathrm{l}$ $2 \times$ HS DyNAmo SYBR green mix, $0.5 \mu$ l each forward and reverse primer $(10 \mu \mathrm{M})$ (Table I), $7 \mu$ nuclease-free water and $2 \mu \mathrm{l}$ cDNA. Amplification was carried out with 40 cycles of $95^{\circ} \mathrm{C}$ for $10 \mathrm{~s}, 60^{\circ} \mathrm{C}$ for $20 \mathrm{~s}$ and $72^{\circ} \mathrm{C}$ for $20 \mathrm{~s}$. Target fluorescence was measured at the end of the $72^{\circ} \mathrm{C}$ step for each cycle. The cDNA expression levels for all samples were normalized to $18 \mathrm{~S}$ expression levels. Relative expression values for each sample were calculated using the $2 \Delta$ ct method (Ramakers et al., 2003).

\section{RESULTS}

\section{GONADAL-SOMATIC INDEX, VITELLOGENIN AND FECUNDITY}

Fadrozole exposure did not elicit treatment-related differences in body or tissue masses or gonadal-somatic index. Exposure to fadrozole for $24 \mathrm{~h}$ or 7 days caused a significant decrease in plasma vitellogenin in female fathead minnows [Fig. 1(a)]. The degree of depression in the $60 \mu \mathrm{g} 1^{-1}$ treatment group was greater after 7 days than that observed after $24 \mathrm{~h}$, suggesting that the effect was dependent on both concentration and duration of exposure. Spawning and fecundity data were not sufficient to support robust statistical analysis. Nonetheless, analysis of total spawns and total fecundity by treatment group suggests that 7days of fadrozole treatment lowered reproductive output [Fig. 1(b)].

\section{MICROARRAY ANALYSIS - BRAIN}

The 2000 gene fathead minnow microarray was used to examine gene expression changes in whole brains from female fathead minnows exposed to $60 \mu \mathrm{g}$ $1^{-1}$ fadrozole for 7 days (GEO series accession no. GSE10722). Of the c. 2000 genes surveyed, 27 unique genes were identified as differentially expressed using the statistical criteria defined for this study (Table II and Appendix 1). Two different probe sequences for cytochrome $b$ and putative $\Delta-6$ fatty acyl desaturase were among the list of genes identified as differentially expressed in brain. Among the unique genes, 20 were up-regulated, while just seven were down-regulated. Estimated fold change, either up or down, relative to controls tended to be small. Among those genes identified as significantly differentially expressed, the gene coding for the isoform of aromatase predominantly expressed in brain showed the greatest fold down-regulation $(-2 \cdot 96)$, while the 


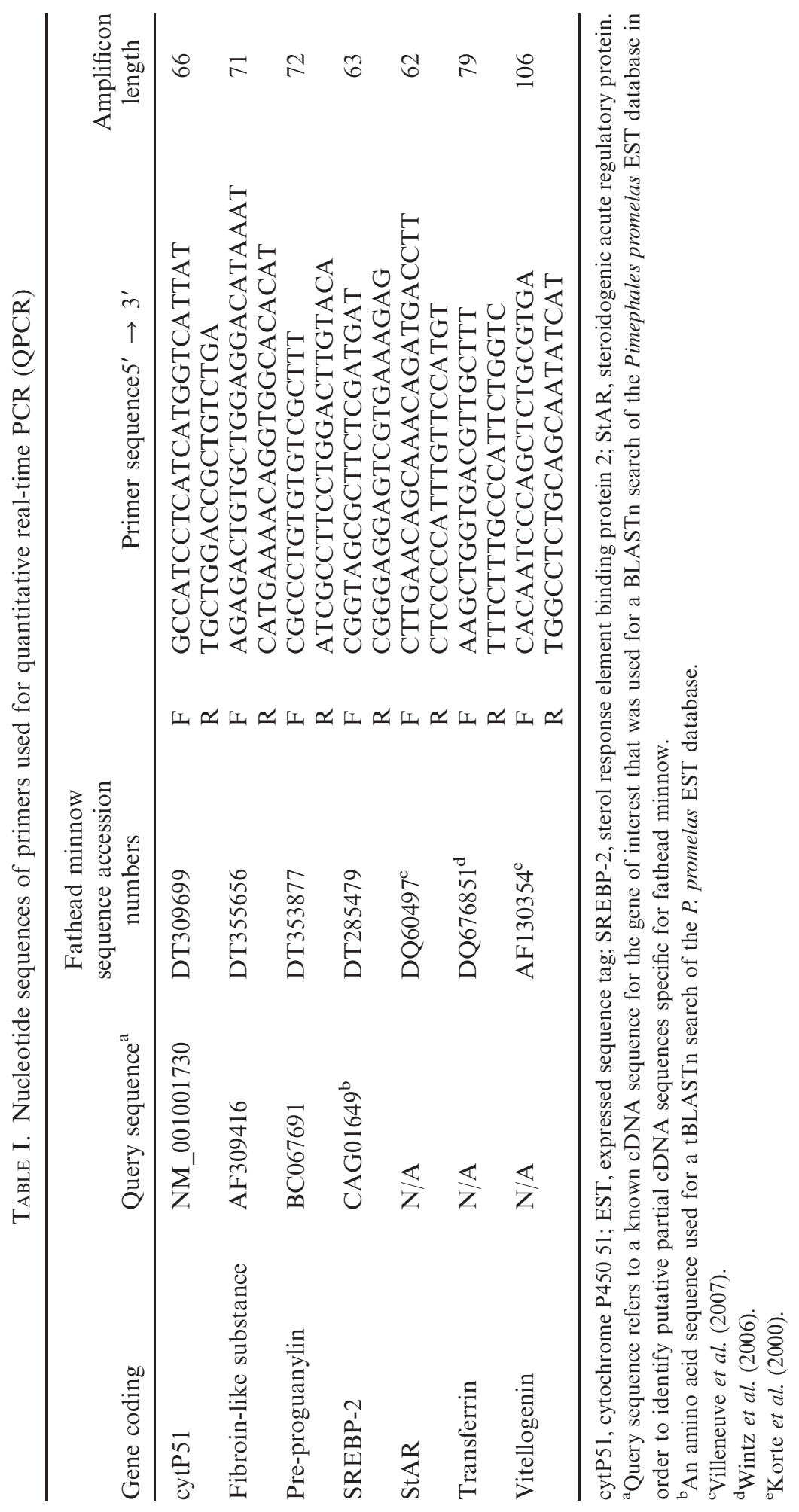



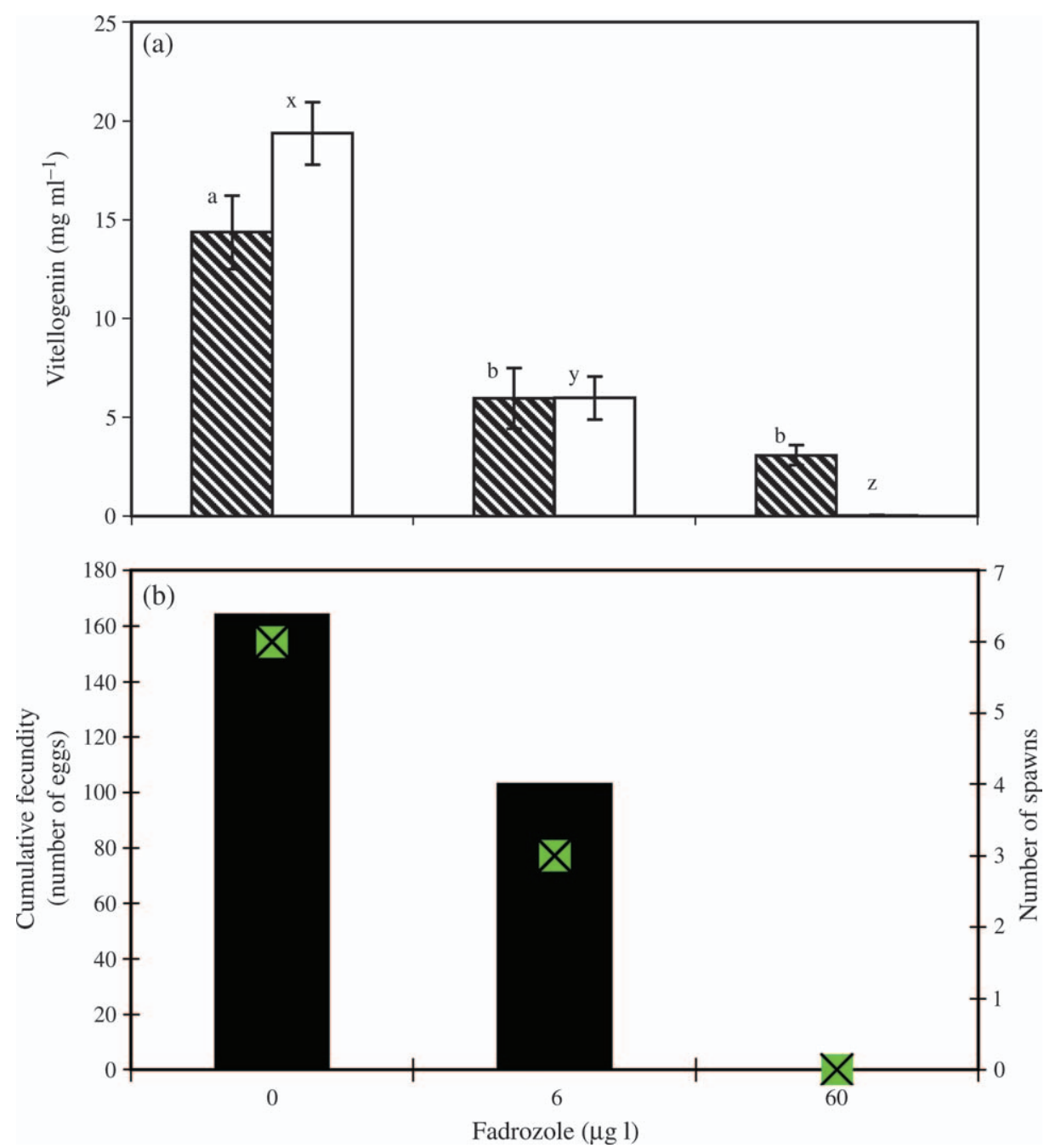

FIG. 1. (a) Plasma vitellogenin concentrations for female fathead minnows exposed to Lake Superior water (control, 0), 6 or $60 \mu \mathrm{g} \mathrm{l}^{-1}$ fadrozole for $24 \mathrm{~h}(\mathbb{\mathbb { N }})$ or 7 days $(\square)$ and (b) cumulative fecundity and numbers of spawns for corresponding pairs of male and female fathead minnows exposed for 7 days. Error bars $=$ standard error $(n=8)$. Different letters indicate statistically significant differences among treatments for a given experiment ( $24 \mathrm{~h}$ or 7 days; $P<0.05)$. Cumulative fecundity and total numbers of spawns are totals across all replicate pairs for each treatment group. $\square$, number of eggs; $\searrow$, number of spawns.

gene coding for 7-dehydrocholesterol reductase showed the greatest fold upregulation (2.06).

The majority of genes identified as differentially expressed had some degree of functional annotation. Using the GO enrichment criteria defined for this study, no GO categories were identified as significantly down-regulated in the brain of fish exposed to fadrozole, even using an expanded gene list based 


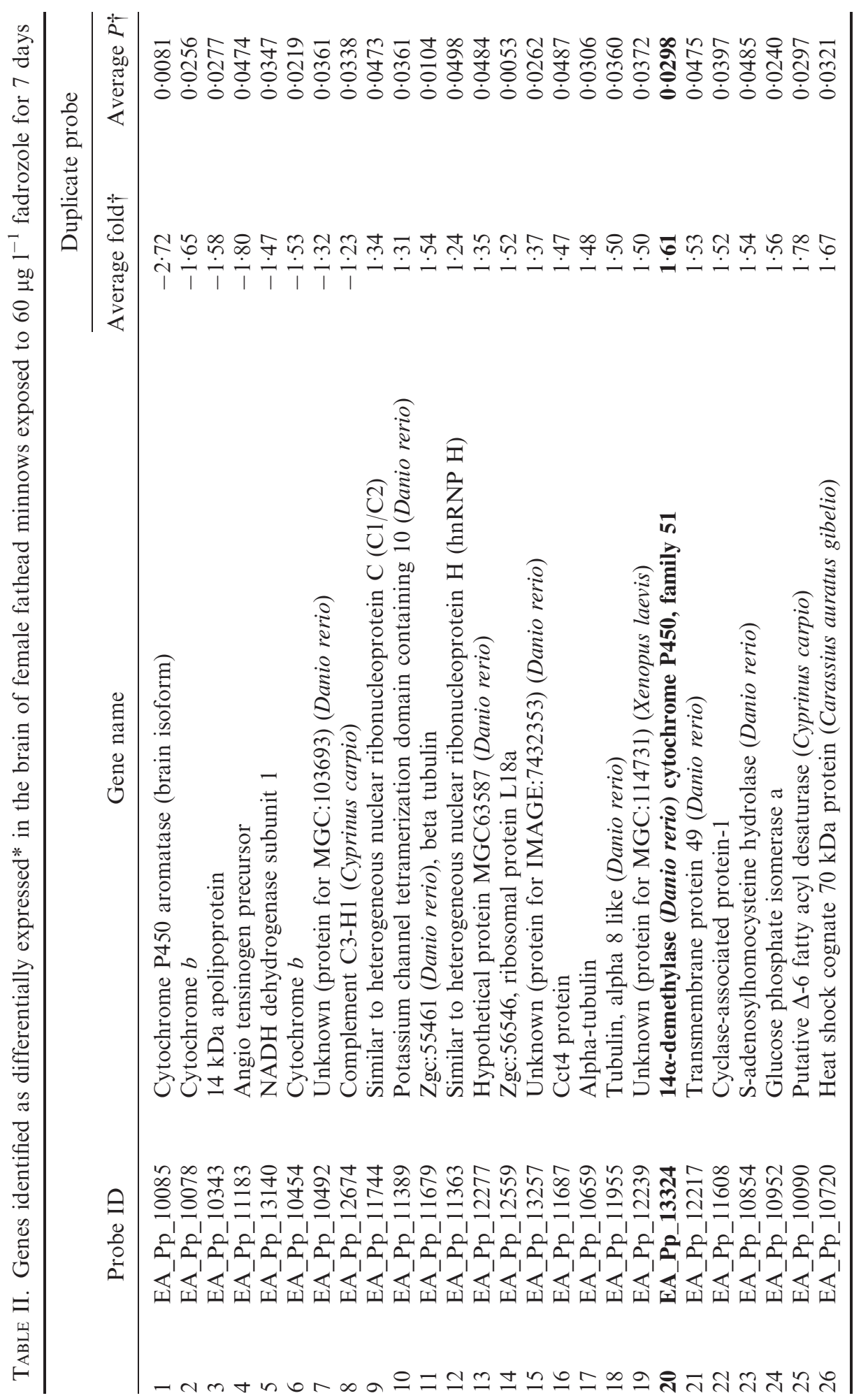




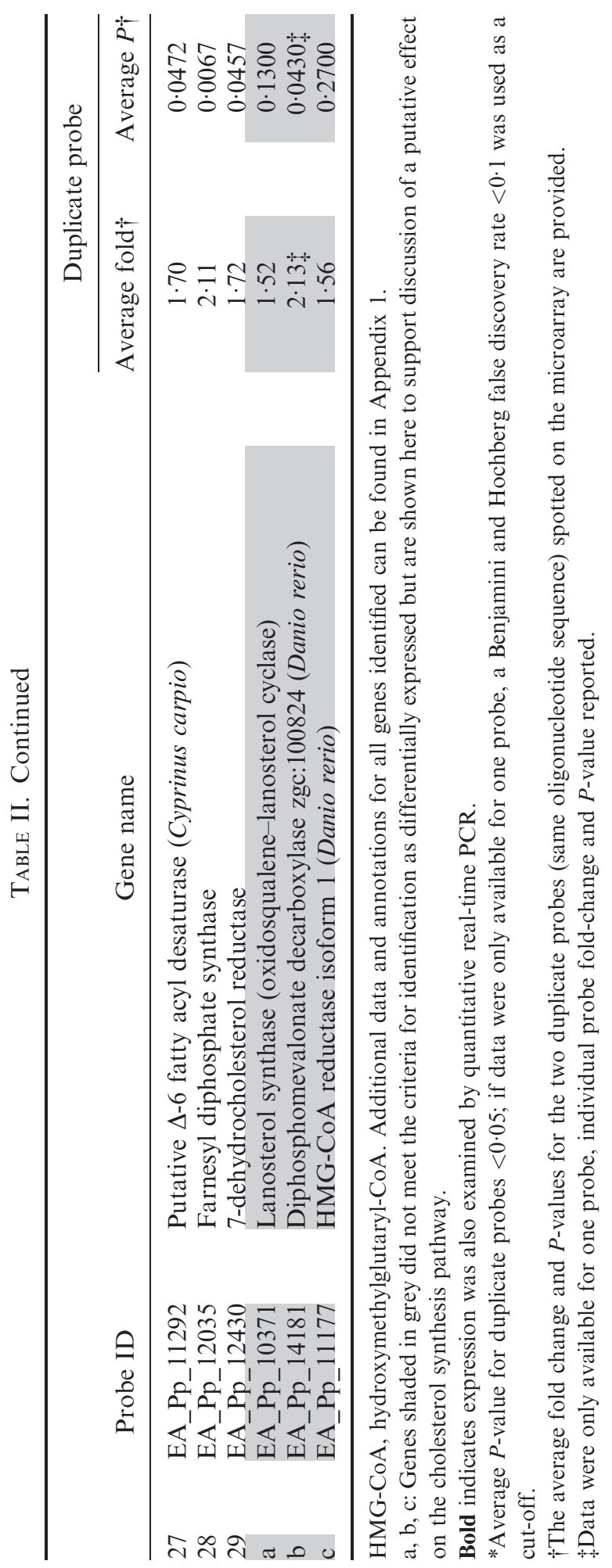


on the relaxed differential expression criteria ( $n=47$ genes). However, a number of up-regulated GO categories were identified. Prominent biological processes represented by the genes up-regulated in brain of fadrozole-exposed fish included lipid biosynthesis-metabolism as well as protein folding and polymerization (Table III). Specific up-regulated genes associated with lipid biosynthesis included putative $\Delta-6$ fatty acyl desaturase (multiple probes), farnesyl diphosphate synthase and 7-dehydrocholesterol reductase. Genes coding for heat-shock cognate $70 \mathrm{kDa}$, Cct4 protein, beta tubulin and unknown protein MGC:114731 were associated with protein polymerization and, or folding. The same GO categories, as well as other related categories, were identified as enriched when an expanded gene list based on the relaxed differential expression criteria was analysed ( $n=61$ genes), adding confidence to the functional analysis of genes up-regulated in brain.

\section{MICROARRAY ANALYSIS - LIVER}

Of the c. 2000 genes surveyed in the livers of females exposed to $60 \mu \mathrm{g} \mathrm{l}^{-1}$ fadrozole for 7 days (GEO series accession no. GSE10722), 41 unique genes were identified as significantly up-regulated using the statistical criteria defined for this study (Appendix 2). Two different probe sequences for a $14 \mathrm{kDa}$ apoplipoprotein were identified as up-regulated (Table IV). Transcripts that hybridized to 69 different oligonucleotide probe sequences were identified as significantly down-regulated (Appendix 3). However, 19 of those probe sequences represented multiple probes for the same gene, vitellogenin. Additionally, three different probe sequences for CG5020-PA isoform A and two different probe sequences for fast muscle troponin I and runt-related transcription factor $\mathrm{b}$, were among the list of genes down-regulated in liver. Overall, 46 unique genes were identified as down-regulated.

The range of fold change observed for genes identified as differentially expressed in liver was greater than that observed for brain. While some differentially expressed genes had fold changes as little as 1.4, transducer of ERBB2 was down-regulated nearly 20 -fold relative to controls, while type 1 cytokeratin (similar to zgc:109868) was up-regulated 8·23-fold (Table IV). Averaging across multiple probes, vitellogenin was the most down-regulated gene (c. $43 \pm$ 17 -fold), but the fold change estimate varied significantly with probe sequence (Appendix 3).

Around $70 \%$ of the genes differentially expressed in liver had some degree biological process GO annotation. Based on that annotation, there was significant enrichment of genes associated with immune-inflammatory response and endocytosis among those identified as up-regulated in the liver of fadrozoleexposed fish (Table V). Enrichment in these categories was driven largely by the up-regulation of three isoforms of complement C3 (Table IV). GO analysis based on an expanded list of putative up-regulated genes ( $n=161 \mathrm{using}$ relaxed differential expression criteria) supported the results of the more conservative analysis, identifying immune response and complement activation as enriched categories. Additionally, the expanded analysis suggested that genes associated with carbohydrate metabolism, specifically gluconeogenesis were among those potentially up-regulated in response to fadrozole treatment. 


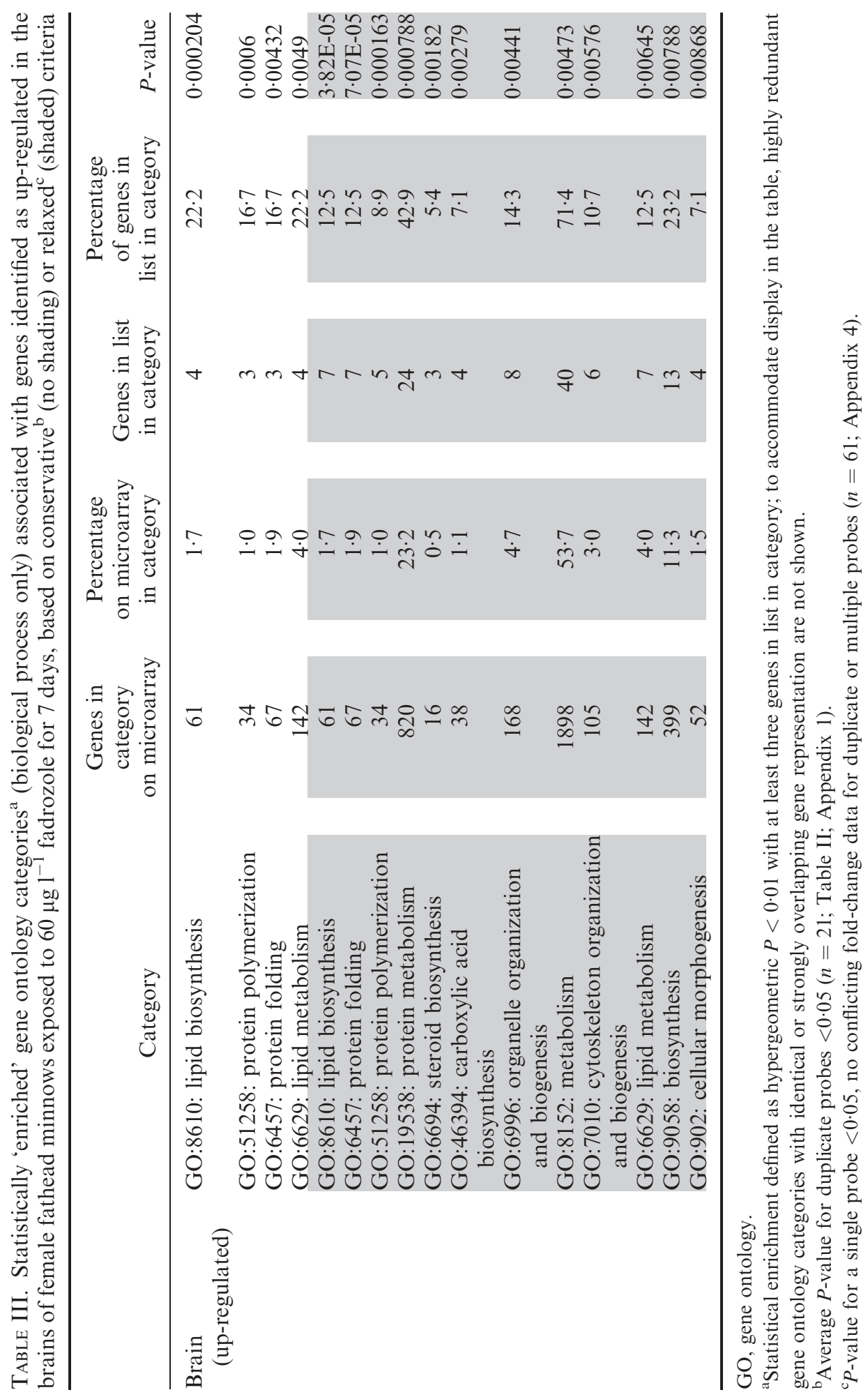




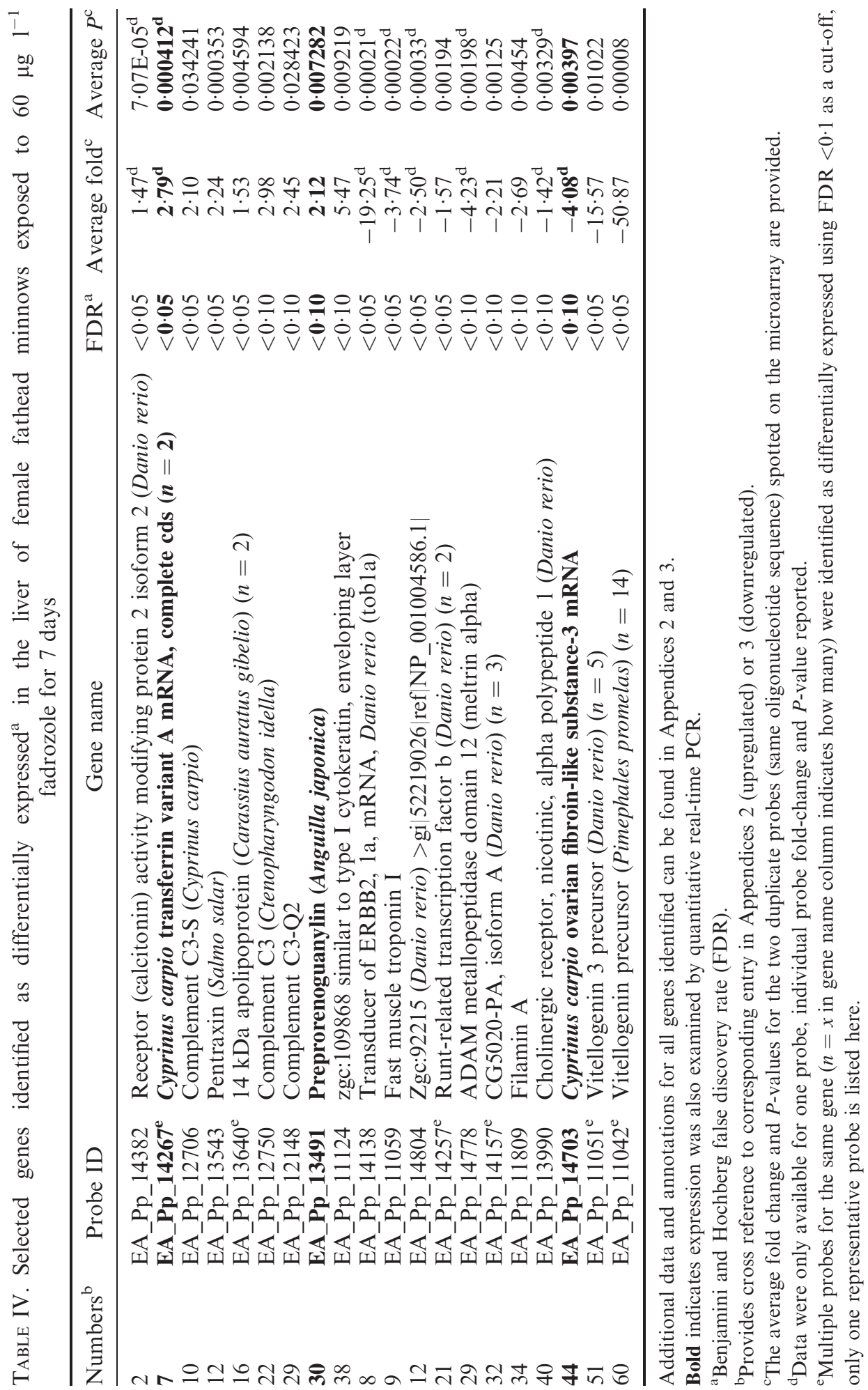




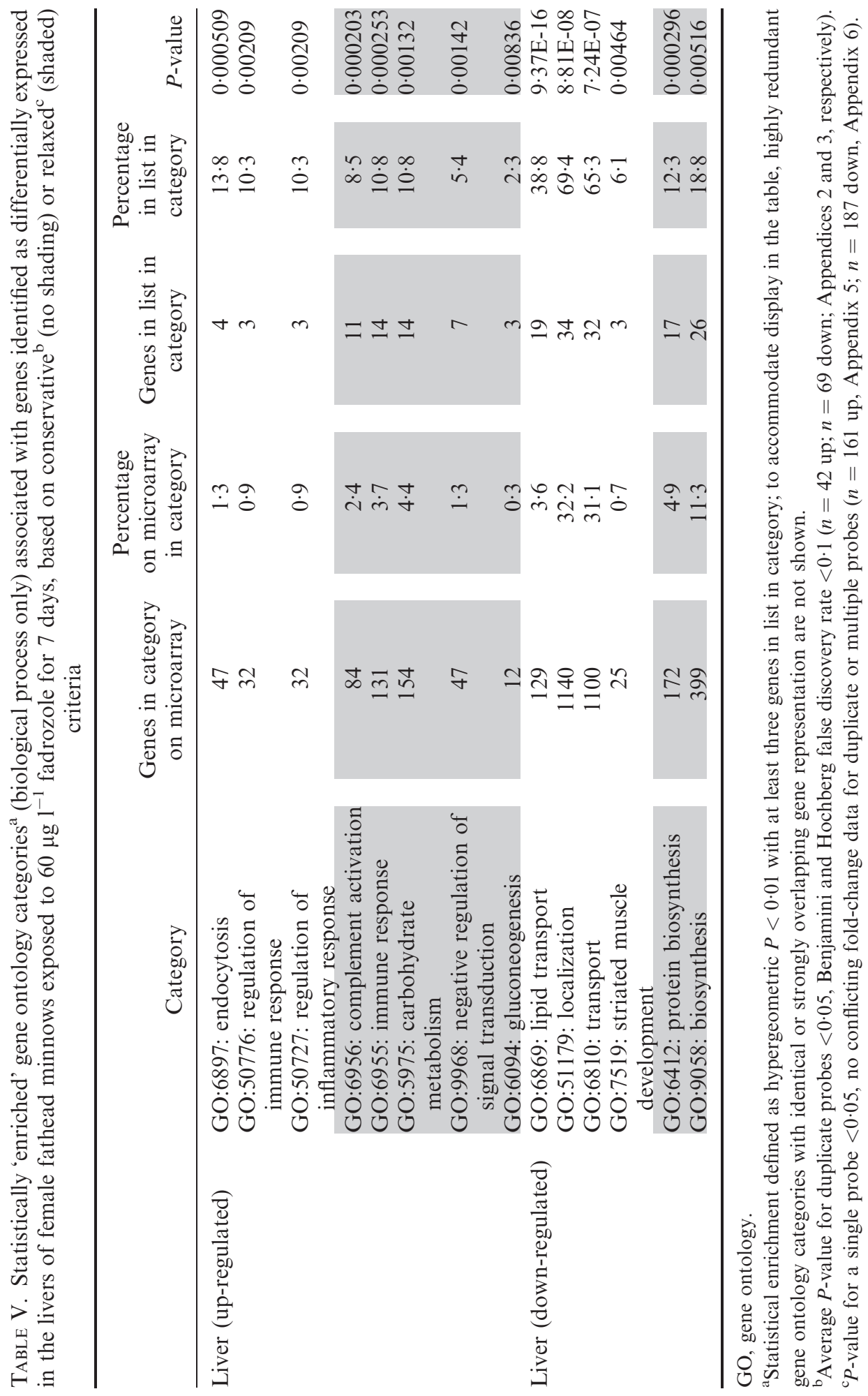


GO analysis based on the more conservative differential expression criteria identified lipid transport, localization, transport and striated muscle development as categories enriched in the list of genes down-regulated in the liver of fadrozole-exposed fish (Table V). Down-regulated genes ostensibly associated with striated muscle development included those coding for filamin B, cholinergic receptor and ADAM metallopeptidase domain 12. Enrichment of lipid transport was solely because of the 19 probes for vitellogenin included on that list. The more general transport and localization categories were associated with the 19 probes for vitellogenin plus 10 other unique down-regulated genes. However, GO analyses based on an expanded, although non-redundant, list did not identify similar terms as enriched. Based on the expanded list, genes associated with biosynthesis, particularly protein biosynthesis, were disproportionately down-regulated in the livers of fadrozole-exposed fish.

\section{QPCR ANALYSES}

QPCR was used to examine the relative expression of six genes in the brains of fadrozole-exposed $v$. control female fathead minnows (Fig. 2). Among the genes examined, cytP51 (14 $\alpha$-demethylase) was the only one that was identified as differentially expressed in brain (Table II). When individual (non-pooled) RNA samples $(n=6)$ were analysed by QPCR, the fold-change in relative abundance of cytP51 transcripts was similar (1.44 v. 1.5-1.6 by microarray), but the difference in means was not statistically significant. Overall, no significant alterations in transcript abundance were detected when individual brain RNA samples were analysed using QPCR.

QPCR analysis of the relative abundance of selected transcripts in liver was more comprehensive. Expression of cytP51, FLS, PPG, transferrin, StAR and SREBP-2 at both time points (24 h and 7days), and all exposure concentrations (0, 6 and $60 \mu \mathrm{g}^{-1}$ fadrozole) was examined (Fig. 3). Vitellogenin expression was evaluated for all three concentrations tested, but only at the 7 days time point. Fadrozole exposure caused significant up-regulation of transferrin expression after both $24 \mathrm{~h}$ and 7 days of exposure. Conversely, the relative abundance of vitellogenin transcripts was significantly reduced by fadrozole exposure. Although cytP51 expression in liver was not significantly affected after 7 days of exposure, cytP51 transcripts were significantly less abundant in the livers of females exposed for $24 \mathrm{~h}$. For the remainder of the genes examined, there were no statistically significant differences in mean transcript abundance.

\section{DISCUSSION}

\section{FATHEAD MINNOW OLIGONUCLEOTIDE MICROARRAYS}

The microarray used for this study was the first generation of high-density oligonucleotide microarrays developed for the fathead minnow, a species with a long history of use in aquatic toxicology research and regulation (Ankley \& Villeneuve, 2006). At the time of its initial development, very few fathead minnow cDNA sequences or ESTs were publicly available and only a 200 gene macroarray had been developed (Klaper et al., 2006; Larkin et al., 2007). Thus, the 

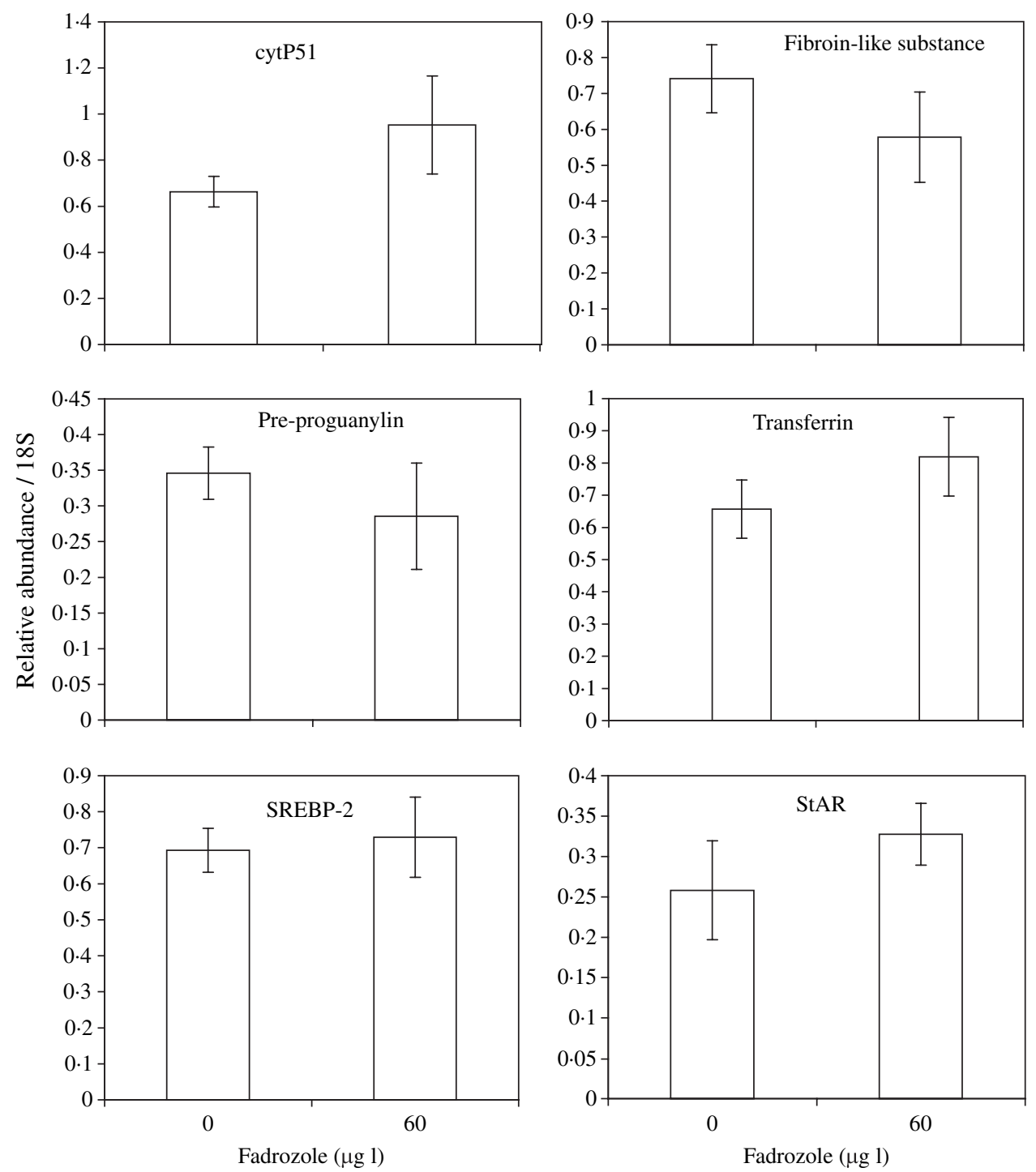

FIG. 2. Transcript abundance of six genes, relative to $18 \mathrm{~S}$ ribosomal RNA abundance, in whole brains from female fathead minnows exposed to Lake Superior water (control, 0) or $60 \mu \mathrm{g}^{-1}$ fadrozole for 7 days as determined by quantitative real-time PCR. Error bars $=$ standard error $(n=6)$. cytP51, cytochrome P450 51 (14 $\alpha$-demethylase); SREBP-2, sterol response element binding protein 2; StAR, steroidogenic acute regulatory protein.

2000 gene microarray, which was commercially available to the scientific community starting in June 2005 , was a significant step forward in facilitating both ecotoxicogenomic and more general transcriptomic research with this species.

However, the technology has progressed rapidly. Subsequent to the initial development and application of the 2000 gene microarray (Larkin et al., 2007; Villeneuve et al., 2007; this study), the Joint Genome Institute sequenced 
250000 cDNA clones from fathead minnows and made the ESTs publicly available in August 2005 (NCBI nucleotide database). Clustering of these EST sequences and addition of more recent cDNA sequences submitted to GenBank yielded over 22000 unique fathead minnow gene sequences that have been incorporated into a new generation of high-density fathead minnow oligonucleotide microarrays available in a variety of formats (http://www.ecoarray. com). These include 22000 gene microarrays with $c .80 \%$ of the genes matched to named genes found in publicly available databases, as well as 15000 gene microarrays that exclude all 'no hit' sequences and duplicates (by accession number). As far as is known, no attempts have been made to validate the use of the fathead minnow microarrays for other species. However, a number of ecotoxicogenomic studies with these higher density commercial fathead minnow microarrays have been conducted (D. Tillitt, pers. comm.; N. Denslow, pers. comm.; B. Carter, pers. comm.), and we expect that the 22000 gene and 15000 gene fathead minnow microarrays will soon be fully described in the peerreviewed literature. Additionally, public availability of the extensive library of fathead minnow ESTs has made it feasible for other investigators and institutions to design and print high-density fathead minnow oligonucleotide microarrays suited to specific research objectives and needs.

\section{EFFICACY OF FADROZOLE EXPOSURE}

Based on its mode of action, inhibition of aromatase activity, fadrozole would be expected to reduce circulating concentrations of oestradiol in exposed fish. Data collected in this study suggest that fadrozole was acting in a manner consistent with its expected mode of action, causing effects similar to those observed in previous experiments with the chemical. For example, fadrozole exposure caused significant, concentration-dependent reductions in plasma vitellogenin concentrations and reduced both the number of spawning events and number of eggs produced by exposed fish. This was consistent with a previous 21 days reproduction test in which fadrozole inhibited brain aromatase activity and reduced plasma concentrations of oestradiol and vitellogenin, vitellogenin uptake into ooctyes and fecundity of the exposed fish (Ankley et al., 2002). Additionally, microarray results from this study indicated significant down-regulation of the gene coding for the brain isoform of aromatase (cytP19B). This effect was consistent with previous work by Villeneuve et al. (2006) as well as reports that cytP19B has an oestrogen response element in its promoter region (Callard et al., 2001; Kazeto et al., 2001). Additional evidence of the efficacy of the fadrozole exposure and its impacts on oestradiol concentrations were provided by gene expression results for liver. Most notably, both microarray and QPCR results showed significant down-regulation of vitellogenin gene expression in the liver. Oestrogen-dependent transcription and translation of vitellogenin has been well established (Arukwe \& Goksøyr, 2003). Furthermore, reduced vitellogenin gene expression agrees with both the results of Ankley et al. (2002) and the plasma vitellogenin concentrations measured in this study. Transferrin was among the genes identified as up-regulated in the livers of fadrozoleexposed females. Transferrin is a key iron transport protein in plasma (Dunn et al., 2007). In medaka, the $5^{\prime}$-promoter region of the transferrin gene contains 
an oestrogen-responsive element (Mikawa et al., 1996), and previous studies with both the fathead minnow and sheepshead minnow reported down-regulation of transferrin expression following oestrogen exposure (Denslow et al., 2001; Larkin et al., 2003, 2007), opposite the effect observed in the fadrozole-exposed fish. As a whole, the consistency of these results with both previous experiments and fadrozole's anticipated mode of action provides strong evidence for the efficacy of the fadrozole exposure.

\section{QPCR VALIDATION}

Relative transcript abundance of five of the genes identified as differentially expressed in either brain or liver, based on microarray analysis, was examined by QPCR. Identification of vitellogenin and transferrin as significantly downregulated and up-regulated in liver, respectively, was supported by consistent, statistically significant effects measured by QPCR. However, the up-regulation of cytP51 (14 $\alpha$-demethylase) in brain and PPG in liver were not supported. The mean transcript abundance of cytP51 in the brain and PPG in the liver of fadrozole-treated fish was somewhat greater than that in control fish; however, because of the variability of the QPCR data the differences were not statistically significant. The QPCR results for FLS in liver indicated non-significant up-regulation of this gene and appeared to contradict the microarray results indicating significant down-regulation, suggesting that the response may be a false positive.

As much as the QPCR results raise questions regarding the validity of specific microarray responses, they raise some question about the validity of the comparison itself. At least in this study, there were numerous factors that could confound meaningful comparison of the statistical significance of the QPCR and microarray results. For example, the microarray analyses were based on three replicate-pooled RNA samples (RNA from two fish per pool) per treatment, while QPCR analyses were conducted on total RNA samples from six to eight individual fish per treatment. Results for cytP51 in brain and PPG in liver suggest that the pooling of RNA samples for the microarray analysis may have masked some of the fish-to-fish variation, resulting in different statistical conclusions for the QPCR and microarray results. Statistical analysis of virtual pools generated by averaging the QPCR data from each pair of samples pooled in the microarray analyses altered the statistical conclusion for PPG expression in the liver (Fig. 3) but not cytP51 expression in brain. This suggested that pooling alone contributed to some of the statistical discrepancies, although not all. While the same RNA samples were used for both analyses, pooled aliquots used for the microarray analyses were reverse transcribed with a poly dTT7 primer, whereas aliquots used for QPCR analysis were reverse transcribed with random hexamers and oligo $\mathrm{d}(\mathrm{T})_{23}$ VN. Furthermore, QPCR responses were normalized to $18 \mathrm{~S}$ ribosomal RNA, while microarray data were globally normalized to a reference sample on a per-gene basis (Larkin et al., 2007). Finally, hybridization efficiencies for the probes spotted on the microarray may differ from those for the primers in a QPCR reaction well. Given these confounding factors, corroborating results can provide a considerable measure of confidence, while a lack of statistical agreement between the two measures 

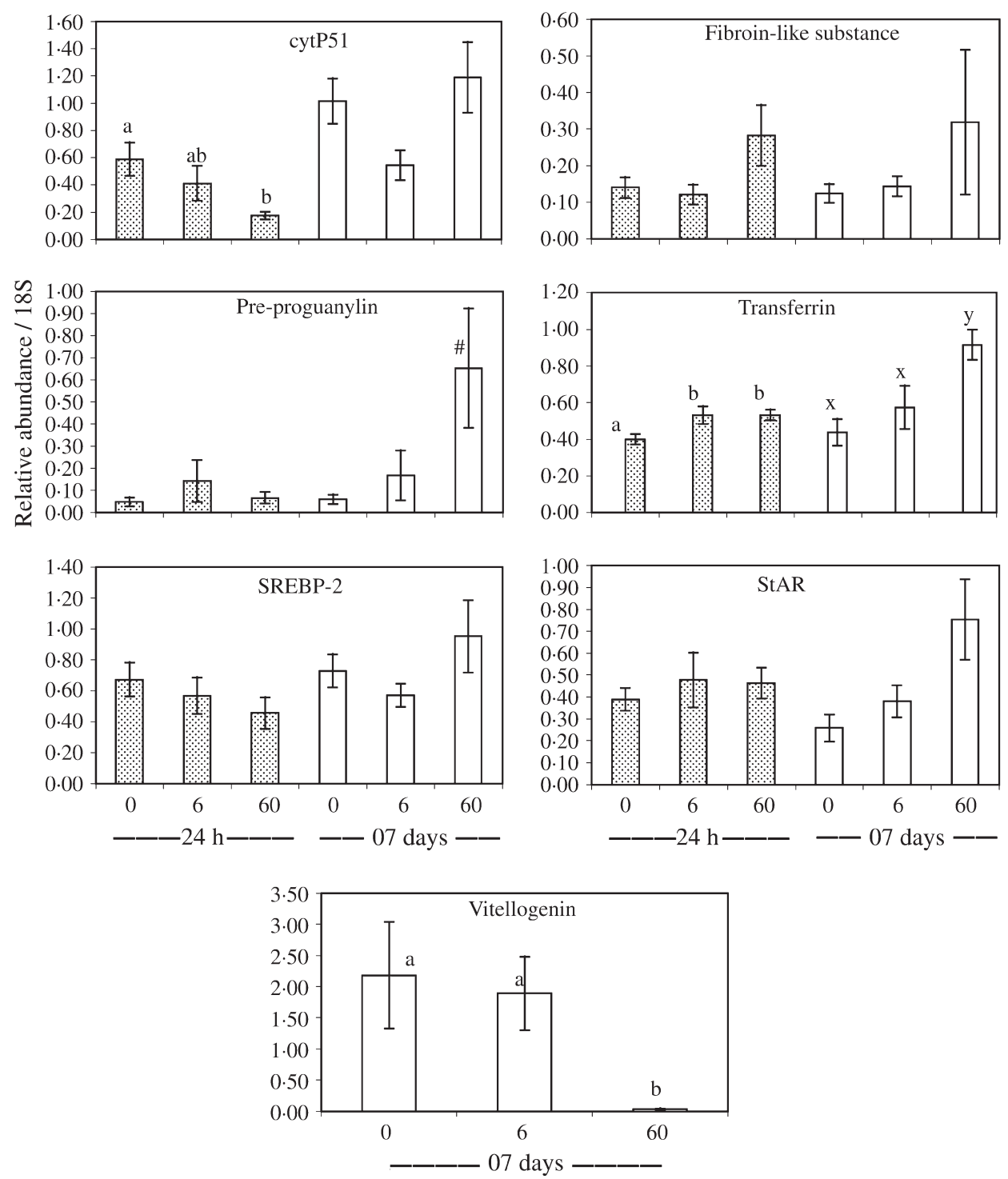

FIG. 3. Transcript abundance of seven genes, relative to $18 \mathrm{~S}$ ribosomal RNA abundance, in livers from female fathead minnows exposed to Lake Superior water (control, 0), 6 or $60 \mu \mathrm{g}{ }^{-1}$ fadrozole for 24 h or 7 days as determined by quantitative real-time PCR. Error bars $=$ standard error $(n=6-8)$. Different letters indicate statistically significant differences among treatments for a given experiment (24 h or 7 days; $P<0.05)$. \# indicates a significant difference $(P<0.05)$ from control following virtual pooling by averaging data for the same samples pooled for the microarray analysis $(n=3)$. cytP51, cytochrome P450 51 (14 $\alpha$-demethylase); SREBP-2, sterol response element binding protein 2; StAR, steroidogenic acute regulatory protein.

may neither support nor refute a given response. The more these types of confounding factors can be controlled and accounted for, the more informative such comparisons will be. Overall, the authors feel that their results highlight 
the need to recognize that a portion of the 'significant' responses identified may be erroneous.

\section{UNSUPERVISED ANALYSIS}

The primary aim of this study was to take advantage of the microarray's capabilities for unsupervised analysis to identify some of the novel molecular responses to fadrozole as a foundation for developing hypotheses that could be investigated in future experiments. In an effort to minimize the reporting of false positives, while still allowing for the identification of some putative differentially expressed genes (i.e. controlling false negative rates), a moderately stringent criterion was applied for defining differentially expressed genes. While this approach should have identified those genes least likely to be false positives, the variability common in microarray experiments, particularly those based on relatively small sample sizes, dictates that one should not ascribe too much significance or confidence to any individual response, as was reinforced by the QPCR results for FLS (above). Consequently, analyses that consider multiple microarray responses (e.g. gene ontology and pathway-based analyses) and weight of evidence (e.g. information in the literature; significance of multiple probes for the same gene) should be more reliable than examination of the genes on a list in isolation, and ultimately microarray responses should be replicated in additional hypothesis-driven experiments.

With these caveats in mind, the microarray analyses did yield a few hypotheses that were based on the weight of evidence of multiple microarray responses. For example, one of the most compelling and internally consistent responses was the up-regulation of multiple enzymes associated with the cholesterol biosynthesis pathway (Fig. 4). Genes coding for three enzymes in the cholesterol synthesis pathway, lanosterol synthase (EC 5.4.99.7), 14 $\alpha$-demethylase (cytP51; EC 1.14.13.70) and 7-dehydrocholesterol reductase (EC 1.3.1.21), were identified as significantly up-regulated in brain after 7 days of exposure to $60 \mu \mathrm{g}^{-1}$ fadrozole. Further evaluation of the microarray annotation and data revealed that genes coding for diphosphomevalonate decarboxylase (EC 4.1.1.33) and farnesyl diphosphate synthase (EC 2.5.1.1) may also have been up-regulated (at least one probe $P<0 \cdot 05$ ). Overall, based on the available annotation and data, the gene coding for hydroxymethylglutaryl-CoA reductase (EC 1.1.1.34) was the only gene from the cholesterol synthesis pathway that was represented on the microarray but did not appear up-regulated in the brain of fadrozoleexposed fish $(P>0 \cdot 25)$. Genes involved in the cholesterol synthesis pathway along with that coding for putative $\Delta-6$ fatty acyl desaturase were responsible for the statistical enrichment of lipid biosynthesis-metabolism identified by GO analyses. As a whole, the pattern of responses observed was suggestive of an overall up-regulation of cholesterol synthesis in the brain.

Cholesterol is both an important structural component of plasma membranes and a precursor for steroid hormones, sterols and bile acids (Chang et al., 2006). Because most plasma lipoproteins cannot cross the blood-brain barrier, with the possible exception of receptor-mediated transcytosis, nearly all cholesterol in the brain is synthesized in the brain (Dehouck et al., 1997; Dietschy \& Turley, 2001; Chang et al., 2006). At the same time, teleost fish 


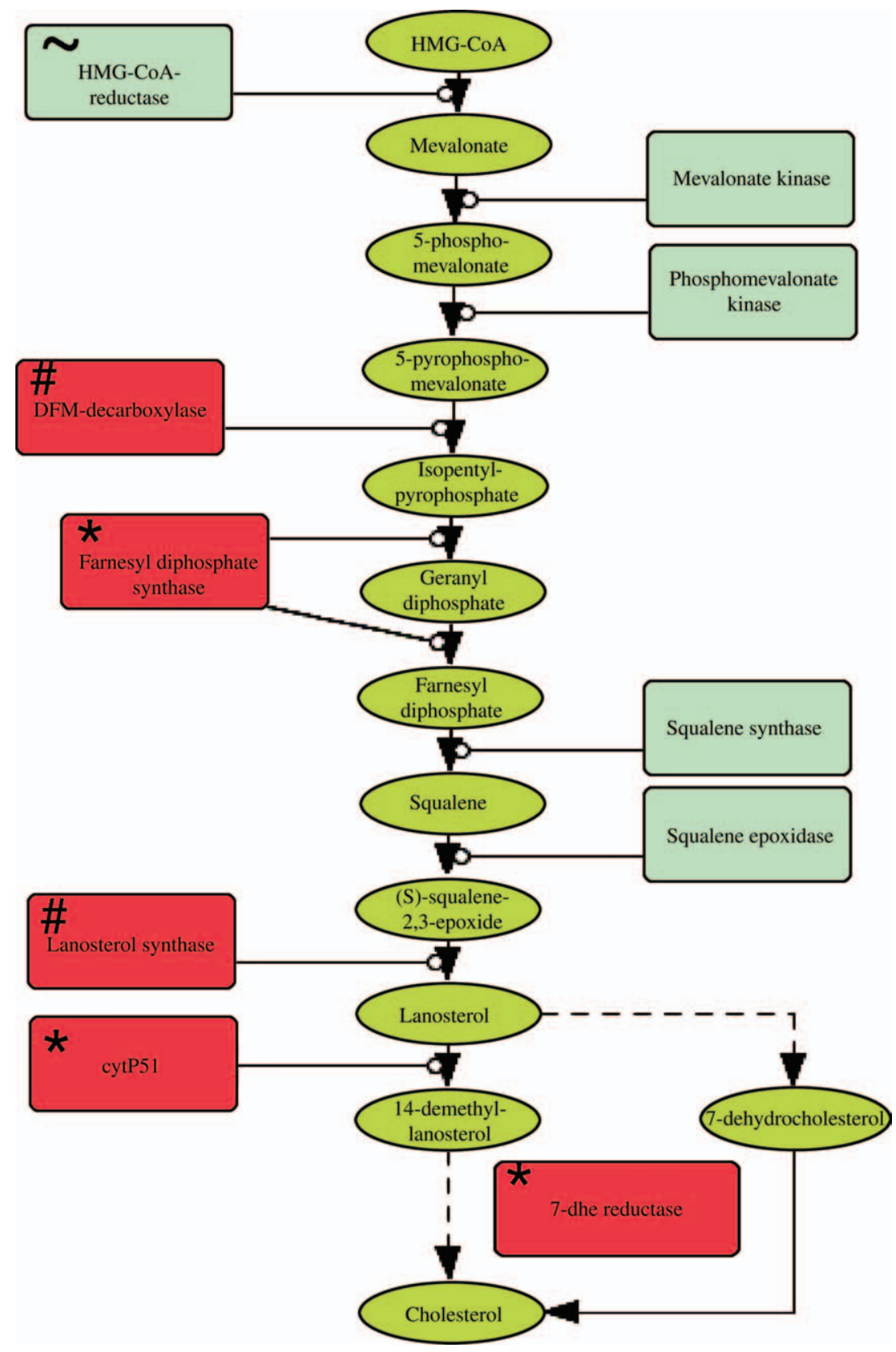

FIG. 4. Graphical model of the cholesterol synthesis pathway showing the role of five enzymes whose corresponding gene expression was up-regulated in the brains of female fathead minnows exposed to $60 \mathrm{~g} \mathrm{l}^{-1}$ fadrozole for $7 \mathrm{~d}$ (red boxes). * denotes genes that conformed to the criteria used to identify differentially expressed genes as part of this study. \# denotes genes present on the microarray with at least one probe response identified as significant using a one-factor $t$-test $(P<0 \cdot 05)$. $\sim$ denotes a gene that was present on the microarray but did not appear affected by fadrozole. Green boxes indicate other enzymes involved in the pathway whose genes were not represented on the microarray. Green ovals indicate cholesterol precursors. 
are known to have very high brain aromatase activity relative to other vertebrates and it has been hypothesized that locally produced oestrogens modulate neurogenesis in adult fish (see reviews by Pellegrini et al., 2005; Forlano et al., 2006). Consequently, up-regulation of cholesterol synthesis in the brain could be viewed as part of a compensatory response to fadrozole's direct inhibition of brain aromatase activity.

Based on that view, the authors hypothesized that expression of StAR or SREBP-2, neither of which were represented on the 2000 gene microarray, might also be up-regulated as part of such a compensatory response. StAR plays a critical role in transporting cholesterol from the outer to inner mitochondrial membrane to support steroidogenesis (Stocco \& Clark, 1996; Stocco, 2001). SREBPs are a class of transcription factors known to activate multiple genes associated with the cholesterol synthesis pathway, including those identified as differentially expressed based on the microarray results. However, based on QPCR analysis neither of these genes was significantly up-regulated in either the brain or liver of fadrozole-exposed female fathead minnows. Over time, additional focused investigation should help test the hypothesis that fadrozole or potentially other steroidogenesis inhibitors will elicit up-regulation of the cholesterol synthesis in brain and reveal the significance and relevance of that response.

A second hypothesis that emerged from examination of the differentially expressed gene lists relates to the down-regulation of cytochrome $b$ and NADH dehydrogenase subunit 1 in brain. These genes are two of just 13 protein-coding genes found within the mitochondrial genome of teleost fish (Miya \& Nishida, 1999; Kartavtsev et al., 2007). Assuming all 13 of the protein-coding mitochondrial genes were present on the 2000 gene microarray, these genes would constitute just $0.65 \%$ of the genes present on the microarray. Given that they represent two of the seven $(28.6 \%)$ unique genes identified as down-regulated in brain, the results suggest an enrichment of down-regulated genes in this class. While two genes in a class might still not seem particularly substantial, additional weight of evidence was provided by the fact that two different probe sequences provided corroborating evidence of an effect on cytochrome $b$ expression. While by no means definitive, the microarray data provides a foundation for hypothesizing that fadrozole treatment affected oxidative phosphorylation and, or mitochondrial abundance in the brain of female fathead minnows.

In liver, the GO-based analyses indicated significant up-regulation of immune-inflammatory response, primarily associated with genes coding for complement factors, and down-regulation of rather general functional categories including localization, transport and possibly protein biosynthesis. Given the large magnitude of hepatic mRNA and protein production needed to support vitellogenesis (Arukwe \& Goksøyr, 2003), one could hypothesize that inhibition of vitellogenin synthesis in female fathead minnows exposed to fadrozole could result in a detectable decrease in the overall amount of protein biosynthesis occurring in the liver, as the GO analyses suggest. If this were true, one would expect to see similar GO-based results in ecotoxicogenomic experiments with other endocrine active chemicals that reduce vitellogenin production in females. The up-regulation of inflammatory-immune response suggests possible tissue damage or trauma in the liver of fadrozole-exposed 
fish. While overt liver toxicity was not an anticipated effect of fadrozole, the authors were not aware of any studies that have explicitly examined this possibility through histological analysis or other methods. Such examination may help reveal whether the complement response observed in this study was an indication of hepatotoxicity or part of a more general stress response to the chemical perturbation.

The hypotheses described above provide examples of utility of unsupervised microarray analysis as a tool for hypothesis generation. Pending further validation of the transcript-level responses and evaluation of their specificity, sensitivity and transience-persistence, some of the genes identified in this study may have utility as either markers of exposure to aromatase inhibitors or predictive indicators of adverse effects similar to those caused by fadrozole. Additionally, examination of the potential linkages between aromatase inhibition and processes like riboflavin metabolism (e.g. down-regulation of flavin adenine dinucleotide synthetase), blood pressure regulation (e.g. down-regulation of angiotensinogen precursor) and ethanol metabolism (e.g. up-regulation of alcohol dehydrogenase 5), among others, through focused testing should lead to an improved and integrated understanding of fish biology. Together, all these lines of investigation should advance the ability to detect and predict responses to chemical stressors.

The work was supported in part through a cooperative research and development agreement (CRADA) between the US EPA and EcoArray (CRADA 301-03). Additional support was provided by the US EPA, Office of Research and Development, National Center for Computational Toxicology. Initial support for D.L.V. was provided by a National Research Council Postdoctoral Research Associateship. We thank D. Bencic for review comments on an earlier version of the manuscript. Thanks also to D. Martinovic for helpful discussion. N. Denslow and P. Larkin developed the fathead minnow microarrays discussed in this publication and hold equity in EcoArray Inc., a for-profit company commercializing the technology. They may benefit from this technology by receiving royalties and equity growth. The information in this document has been subjected to review by the US EPA National Health and Environmental Effects Research Laboratory and approved for publication. Approval does not signify that the contents reflect the views of the Agency nor does mention of trade names or commercial products constitute endorsement or recommendation for use.

\section{References}

Ankley, G. T. \& Villeneuve, D. L. (2006). The fathead minnow in aquatic toxicology: past, present, and future. Aquatic Toxicology 78, 91-102.

Ankley, G. T., Kahl, M. D., Jensen, K. M., Hornung, M. W., Korte, J. J., Makynen, E. A. \& Leino, R. L. (2002). Evaluation of the aromatase inhibitor fadrozole in a short-term reproduction assay with the fathead minnow (Pimephales promelas). Toxicological Sciences 67, 121-130.

Ankley, G. T., Daston, G. P., Degitz, S. J., Denslow, N. D., Hoke, R. A., Kennedy, S. W., Miracle, A. L., Perkins, E. J., Snape, J., Tillitt, D. E., Tyler, C. R. \& Versteeg, D. (2006). Toxicogenomics in regulatory ecotoxicology. Environmental Science \& Technology 40, 4055-4065.

Arukwe, A. \& Goksøyr, A. (2003). Eggshell and egg yolk proteins in fish: hepatic proteins for the next generation: oogenetic, population, and evolutionary implications of endocrine disruption. Comparative Hepatology 2, 4. 
Benjamini, Y.\& Hochberg, Y. (1995). Controlling the false discovery rate: a practical and powerful approach to multiple testing. Journal of the Royal Statistical Society B 57, 289-300.

Callard, G. V., Tchoudakova, A. V., Kishida, M. \& Wood, E. (2001). Differential tissue distribution, developmental programming, estrogen regulation and promoter characteristics of cyp 19 genes in teleost fish. Journal of Steroid Biochemistry and Molecular Biology 79, 305-314.

Chang, T.-Y., Chang, C. C. Y., Ohgami, N. \& Yamauchi, Y. (2006). Cholesterol sensing, trafficking, and esterification. Annual Review of Cell and Developmental Biology 22, 129-157.

Dehouck, B., Fenart, L., Dehouck, M.-P., Pierce, A., Torpier, G. \& Cecchelli, R. (1977). A new function for the LDL receptor: transcytosis of LDL across the blood-brain barrier. Journal of Cell Biology 138, 877-889.

Denslow, N. D., Bowman, C. J., Ferguson, R. J., Lee, H. S., Hemmer, M. J. \& Folmar, L. C. (2001). Induction of gene expression in sheepshead minnows (Cyprinodon variegatus) treated with 17 beta-estradiol, diethylstilbestrol, or ethinylestradiol: the use of mRNA fingerprints as an indicator of gene regulation. General and Comparative Endocrinology 121, 250-260.

Dietschy, J. M. \& Turley, S. D. (2001). Cholesterol metabolism in the brain. Current Opinion in Lipidology 12, 105-112.

Dunn, L. L., Rahmanto, Y. S. \& Richardson, D. R. (2007). Iron uptake and metabolism in the new millennium. Trends Cell Biology 17, 93-100.

Forlano, P. M., Schlinger, B. A. \& Bass, A. H. (2006). Brain aromatase: new lessons from non-mammalian model systems. Frontiers in Neuroendocrinology 27, 247-274. doi: 10.1016/j.yfrne.2006.05.002

Gene Ontology Consortium (2006). The gene ontology (GO) project in 2006. Nucleic Acids Research 34, D322-D326.

Kartavtsev, Y. P., Jung, S. O., Lee, Y. M., Byeon, H. K. \& Lee, J. S. (2007). Complete mitochondrial genome of the bullhead torrent catfish, Liobagrus obesus (Siluriformes, Amblycipididae): genome description and phylogenetic considerations inferred from the Cyt b and 16S rRNA genes. Gene 396, 13-27.

Kazeto, Y., Ijiri, S., Place, A., Zohar, Y. \& Trant, J. (2001). The 5'-flanking regions of cytP19A1 and cytP19A2 in zebrafish. Biochemical and Biophysical Research Communications 288, 503-508.

Kishi, K., Kitagawa, E., Onikura, N., Nakamura, A. \& Iwahashi, H. (2006). Expression analysis of sex-specific and 17ß-estradiol-responsive genes in the Japanese medaka, Oryzias latipes, using oligonucleotide microarrays. Genomics 88, 241-251.

Klaper, R., Rees, C. B., Drevnick, P., Weber, D., Sandheinrich, M., Carvan, M. J. (2006). Gene expression changes related to endocrine function and decline in reproduction in fathead minnow (Pimephales promelas) after dietary methylmercury exposure. Environmental Health Perspectives 114, 1337-1343.

Knoebl, I., Blum, J. L., Hemmer, M. J. \& Denslow, N. D. (2006). Temporal gene induction patterns in sheepshead minnow exposed to $17 \beta$-estradiol. Journal of Experimental Zoology Part A: Comparative Experimental Biology 305, 707-719.

Korte, J. J., Kahl, M. D., Jensen, K. M., Pasha, M. S., Parks, L. G., LeBlanc, G. A. \& Ankley, G. T. (2000). Fathead minnow vitellogenin: complementary DNA sequence and messenger RNA and protein expression after $17 \beta$-estradiol treatment. Environmental Toxicology and Chemistry 19, 972-981.

Larkin, P., Sabo-Attwood, T., Kelso, J. \& Denslow, N. D. (2002). Gene expression analysis of largemouth bass exposed to estradiol, nonylphenol, and p,p'-DDE. Comparative Biochemistry and Physiology B 133, 543-557.

Larkin, P., Folmar, L. C., Hemmer, M. J., Poston, A. J. \& Denslow, N. D. (2003). Expression profiling of estrogenic compounds using a sheepshead minnow cDNA macroarray. Environmental Health Perspectives Toxicogenomics 111, 29-36.

Larkin, P., Villeneuve, D. L., Knoebl, I., Miracle, A. L., Carter, B. J., Liu, L., Denslow, N. D. \& Ankley, G. T. (2007). Development and validation of a 2000-gene 
microarray for the fathead minnow (Pimephales promelas). Environmental Toxicology and Chemistry 26, 1497-1506.

Mikawa, N., Hirono, I. \& Aoki, T. (1996). Structure of medaka transferrin gene and its 5'-flanking region. Molecular Marine Biology and Biotechnology 5, 225-229.

Miya, M. \& Nishida, M. (1999). Organization of the mitochondrial genome of a deep-sea fish, Gonostoma gracile (Teleostei: Stomiiformes): first example of transfer RNA gene rearrangements in bony fishes. Marine Biotechnology 1, 416-426.

Pellegrini, E., Menuet, A., Lethimonier, C., Adrio, F., Guegen, M. M., Tascon, C., Anglade, I., Pakdel, F. \& Kah, O. (2005). Relationships between aromatase and estrogen receptors in the brain of teleost fish. General and Comparative Endocrinology 142, 60-66.

Ramakers, C., Ruijter, J. M., Lekanne Deprez, R. H. \& Moorman, A. F. M. (2003). Assumption-free analysis of quantitative real-time polymerase chain reaction (PCR) data. Neuroscience Letters 339, 62-66.

Simpson, E. R., Mahendroo, M. S., Means, G. D., Kilgore, M. W., Hinshelwood, M. M., Graham-Lorence, S., Amarneh, B., Ito, Y., Fisher, C. R., Michael, M. D., Mendelsen, C. R. \& Bulun, S. E. (1994). Aromatase cytochrome P450, the enzyme responsible for estrogen synthesis. Endocrine Reviews 15, 342-355.

Stocco, D. M. (2001). StAR protein and the regulation of steroid hormone biosynthesis. Annual Review of Physiology 63, 193-213.

Stocco, D. M. \& Clark, B. J. (1996). Regulation of the acute production of steroids in steroidogenic cells. Endocrine Reviews 17, 221-244.

US EPA. (2002). A short-term test method for assessing the reproductive toxicity of endocrine-disrupting chemicals using the fathead minnow (Pimephales promelas). EPA/600/R-01/067. Duluth, MN: US EPA, Office of Research and Development, National Health and Environmental Effects Research Laboratory. Mid-Continent Ecology Division.

Villeneuve, D. L., Knoebl, I., Kahl, M. D., Jensen, K. M., Hammermeister, D. E., Green, K. J., Blake, L. S. \& Ankley, G. T. (2006). Relationship between brain and ovary aromatase activity and isoform-specific aromatase mRNA expression in the fathead minnow (Pimephales promelas). Aquatic Toxicology 76, 353-368.

Villeneuve, D. L., Larkin, P., Knoebl, I., Miracle, A. L., Kahl, M. D., Jensen, K. M., Makynen, E. A., Durhan, E. J., Carter, B. J., Denslow, N. D. \& Ankley, G. T. (2007). A graphical systems model to facilitate hypothesis-driven ecotoxicogeno mics research on the teleost brain-pituitary-gonadal axis. Environmental Science \& Technology 41, 321-330.

Wintz, H., Yoo, L. J., Loguinov, A., Wu, Y. Y., Steevens, J. A., Holland, R. D., Berger, R. D., Perkins, E. J., Hughes, O. \& Vulpe, C. D. (2006). Gene expression profiles in fathead minnows exposed to 2,4-DNT: correlation with toxicity in mammals. Toxicological Sciences 94, 71-82. 


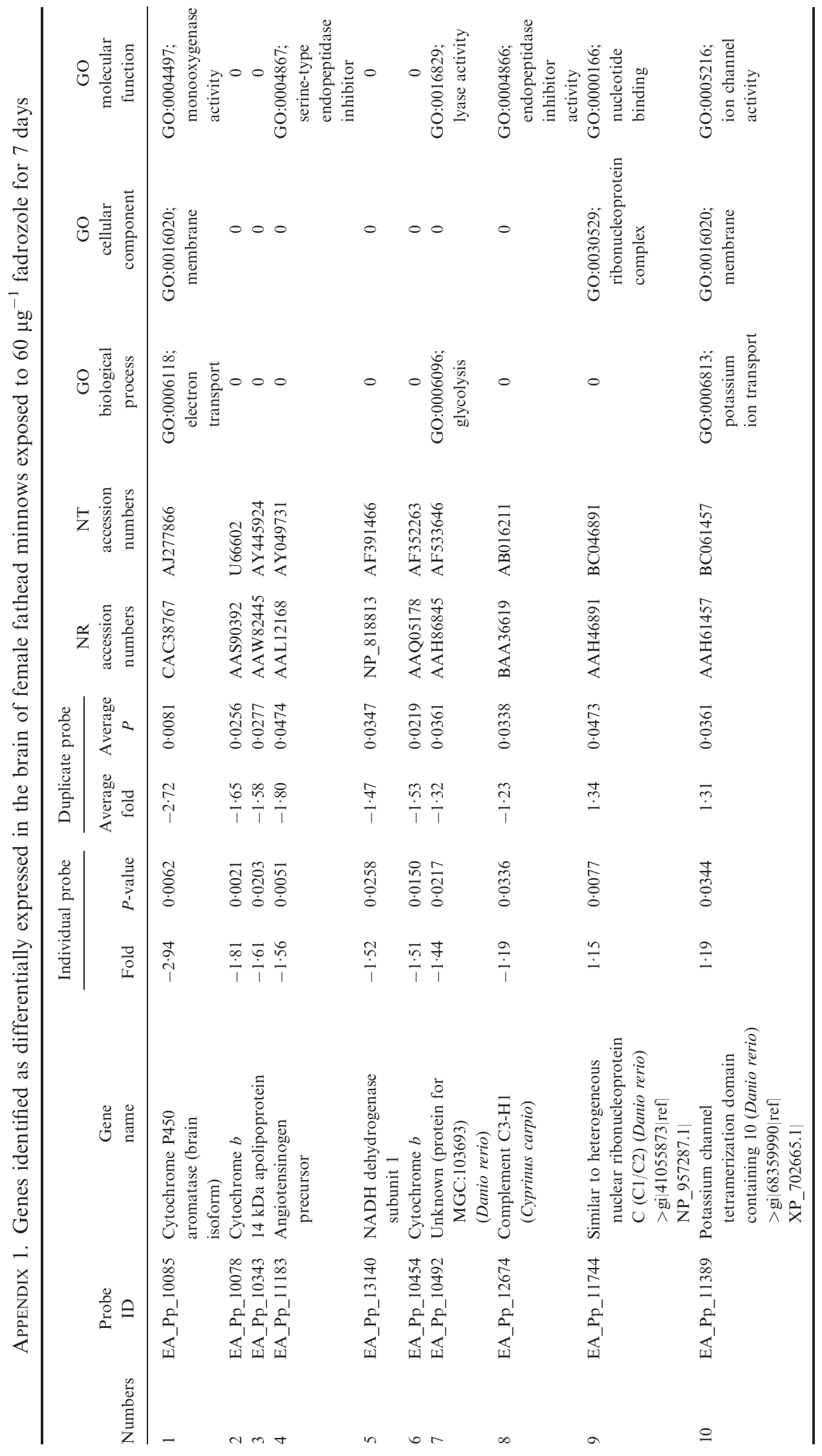




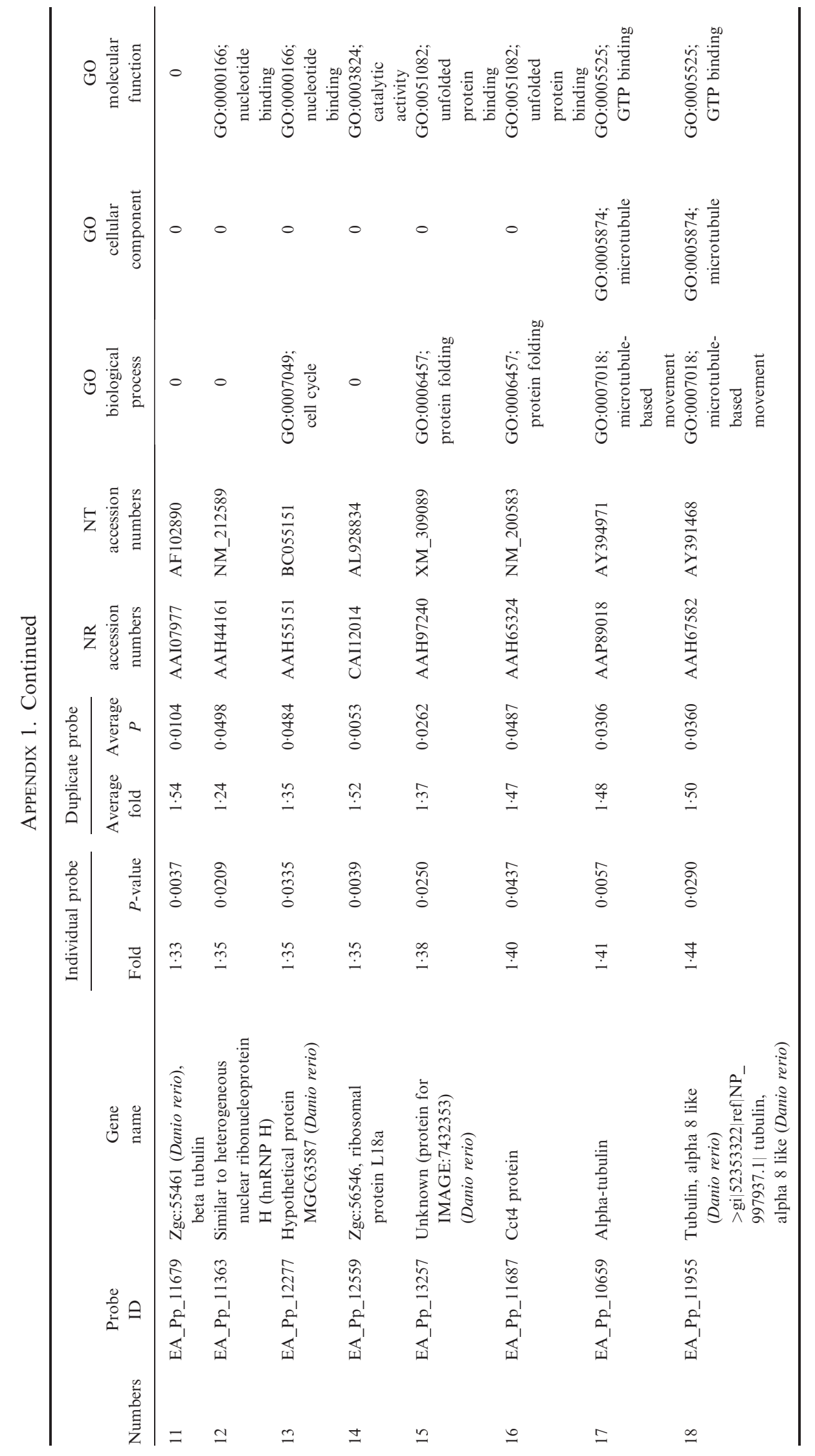




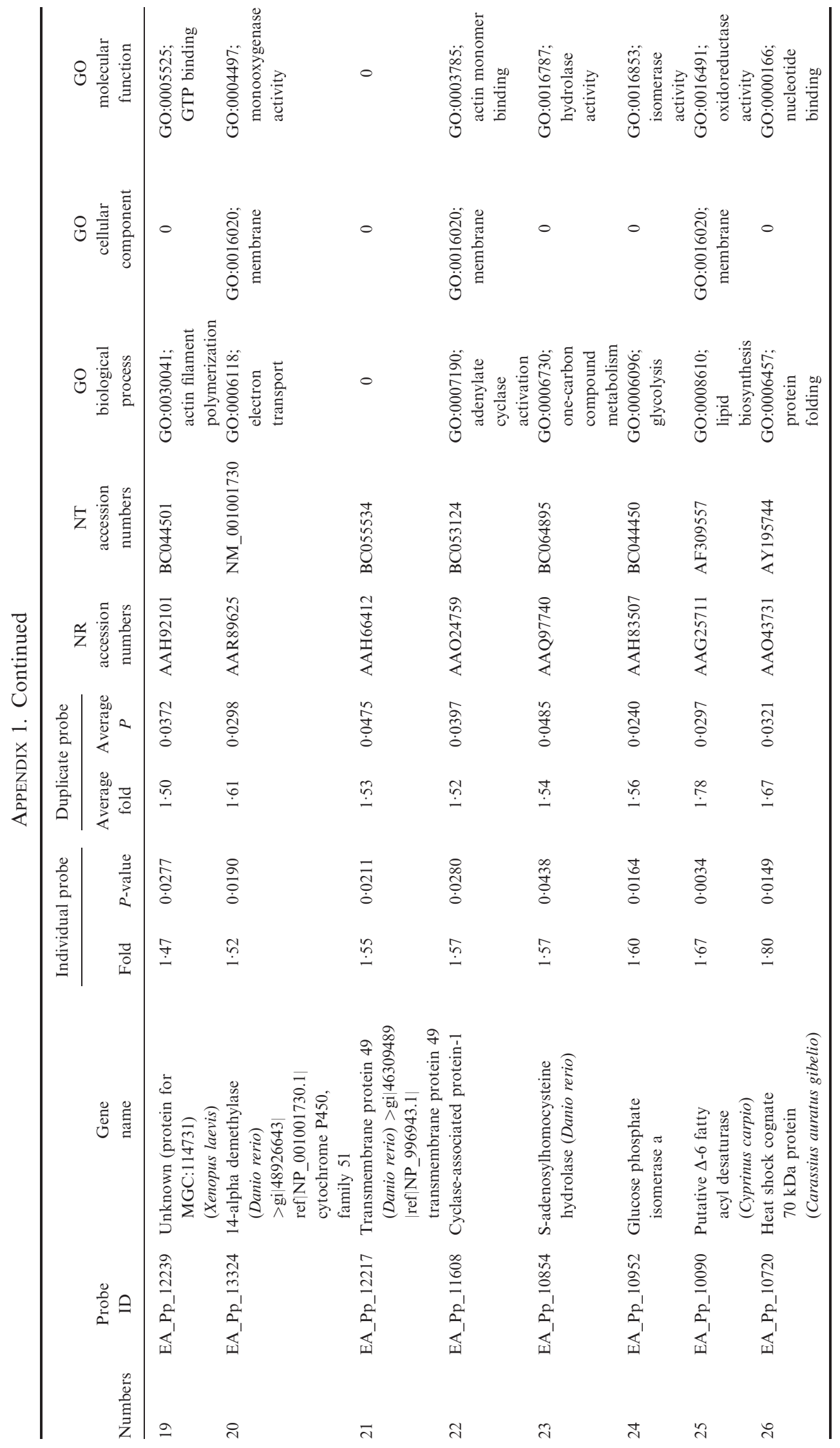




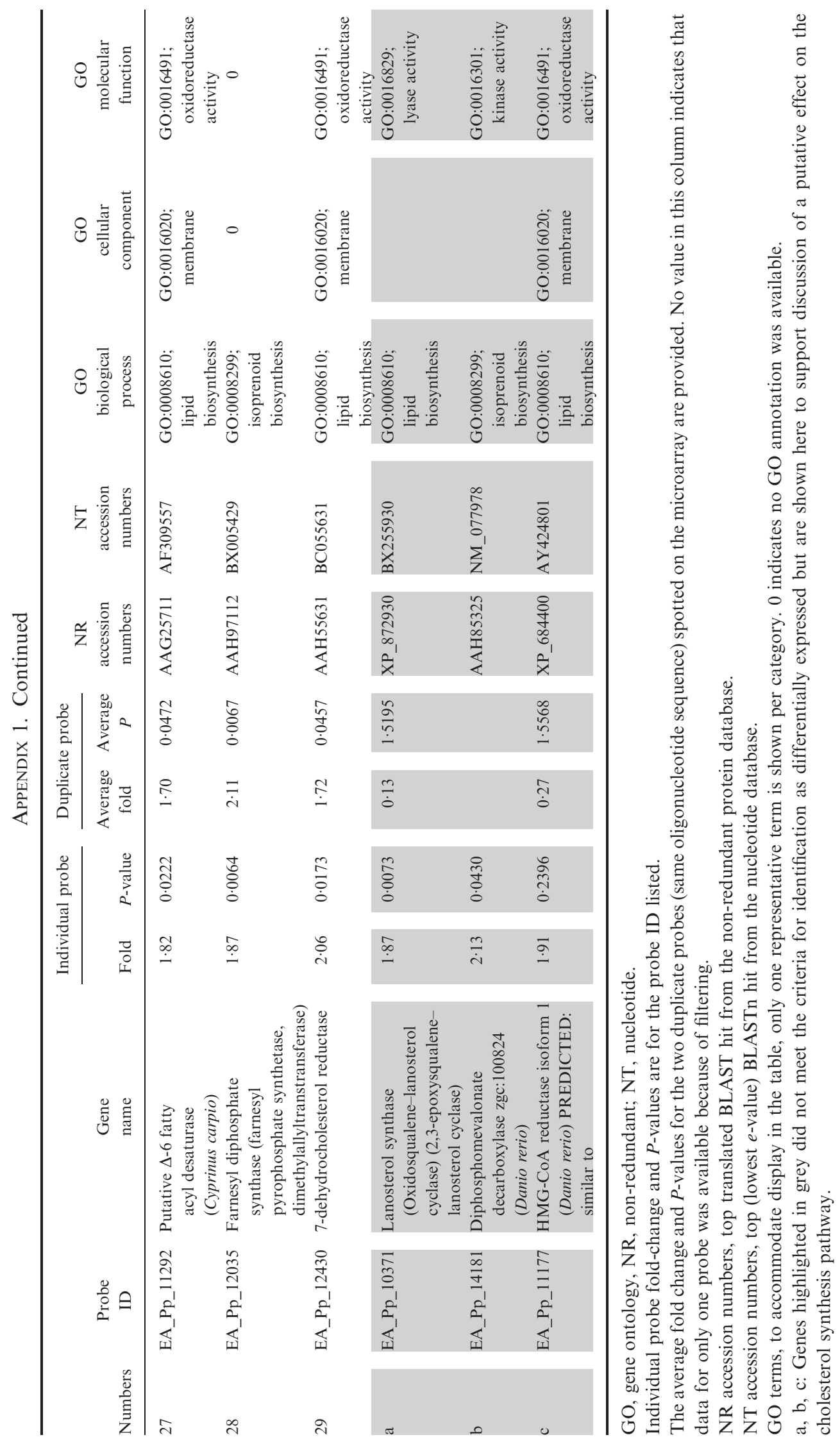




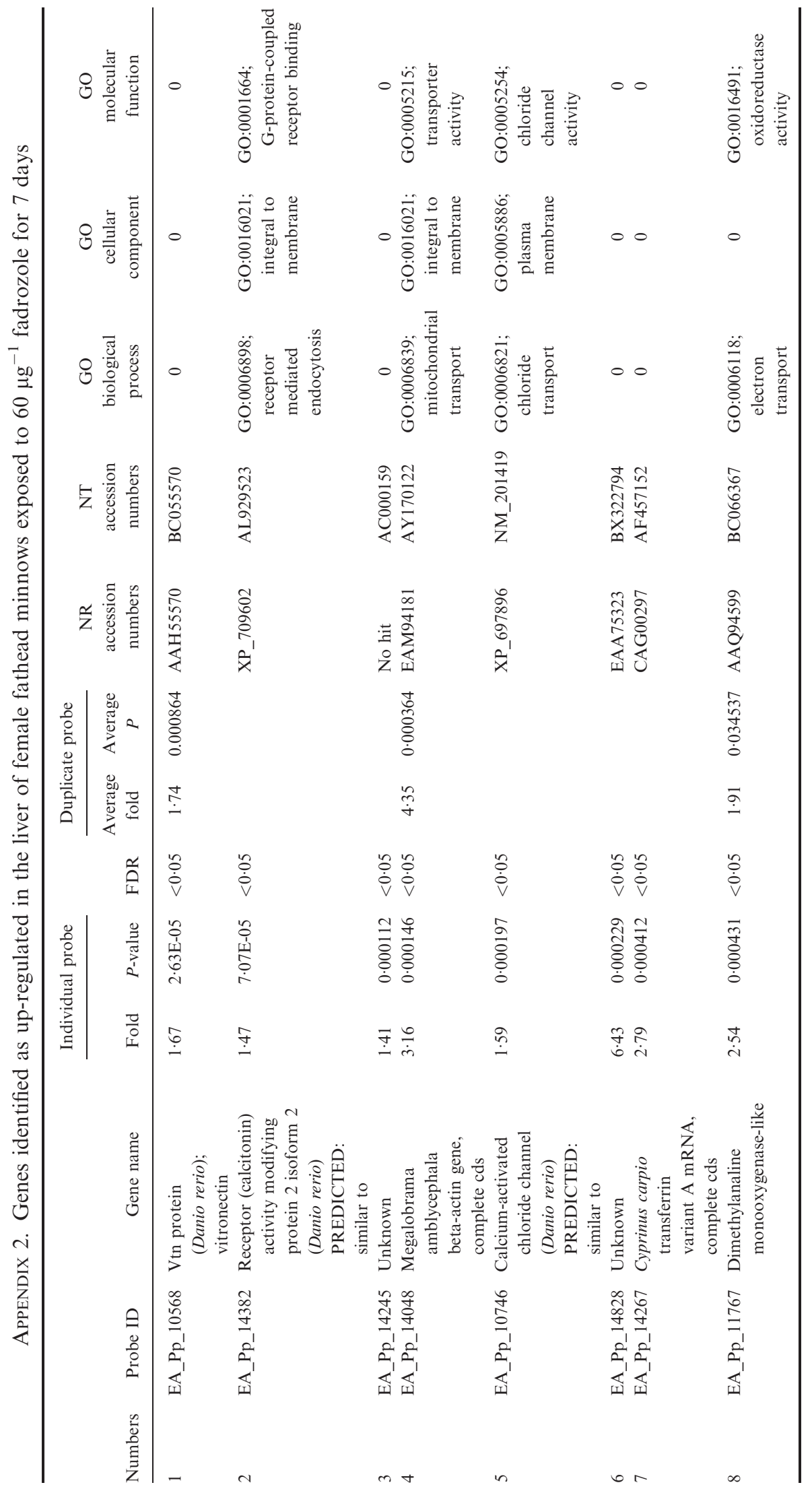




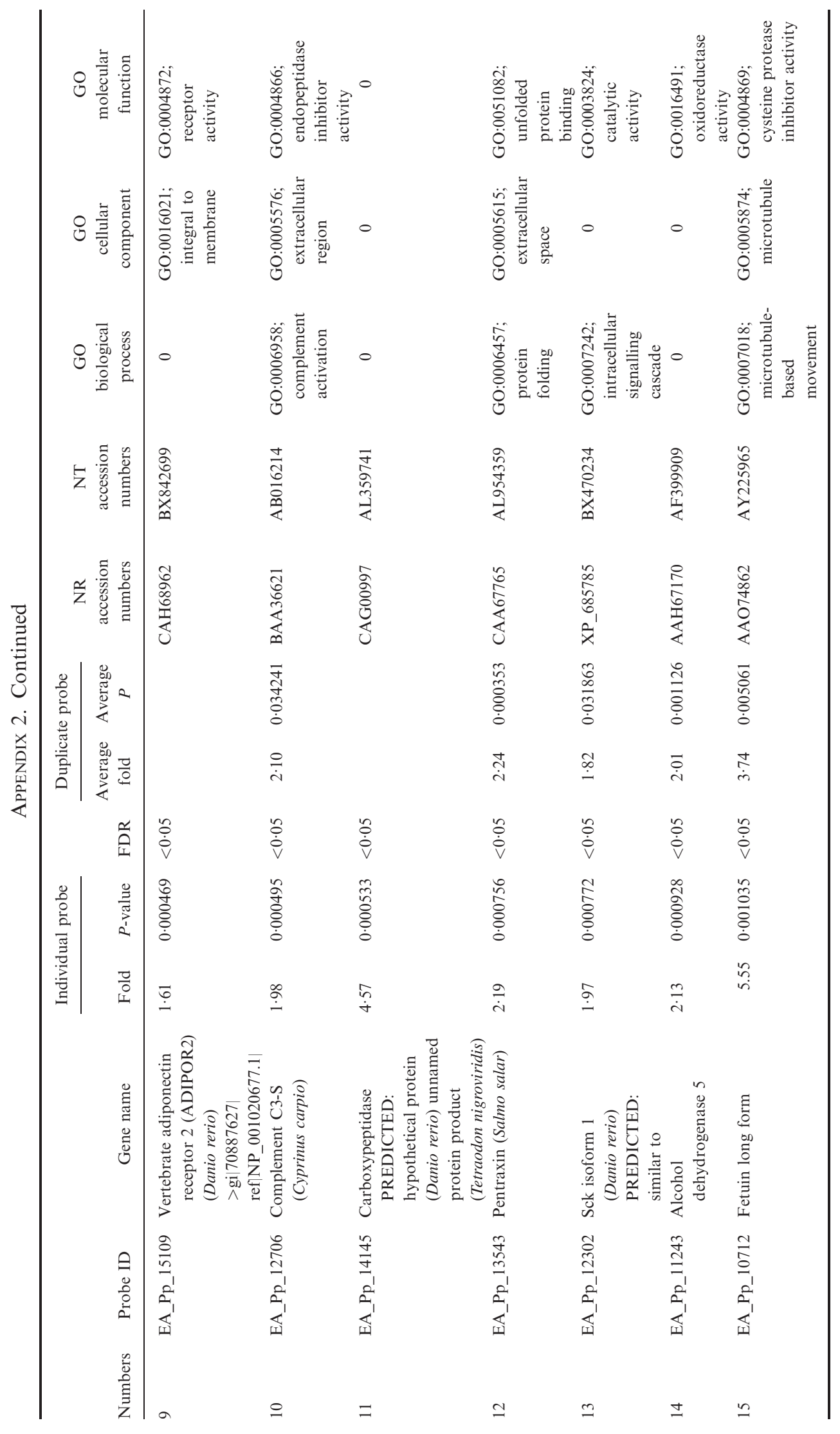




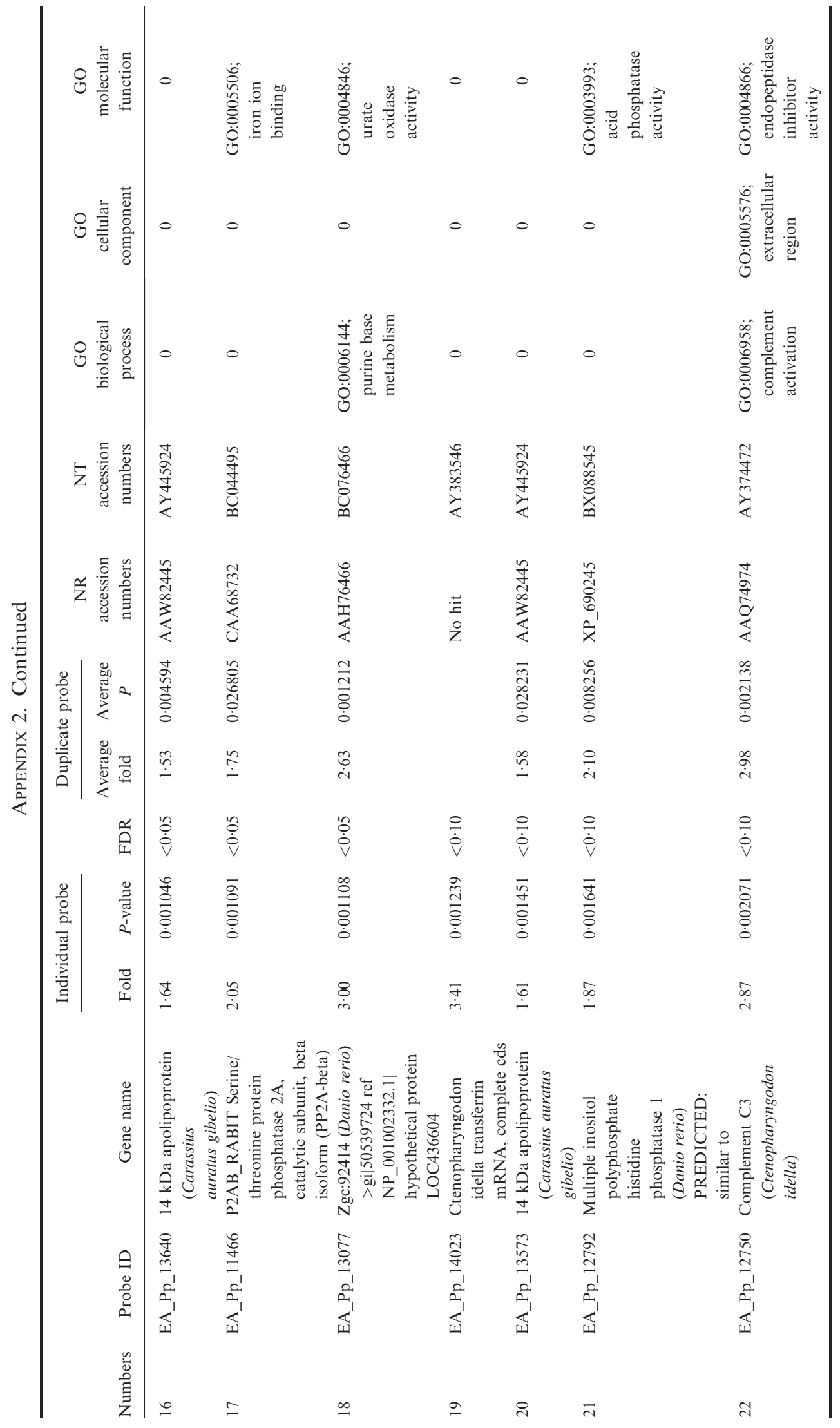




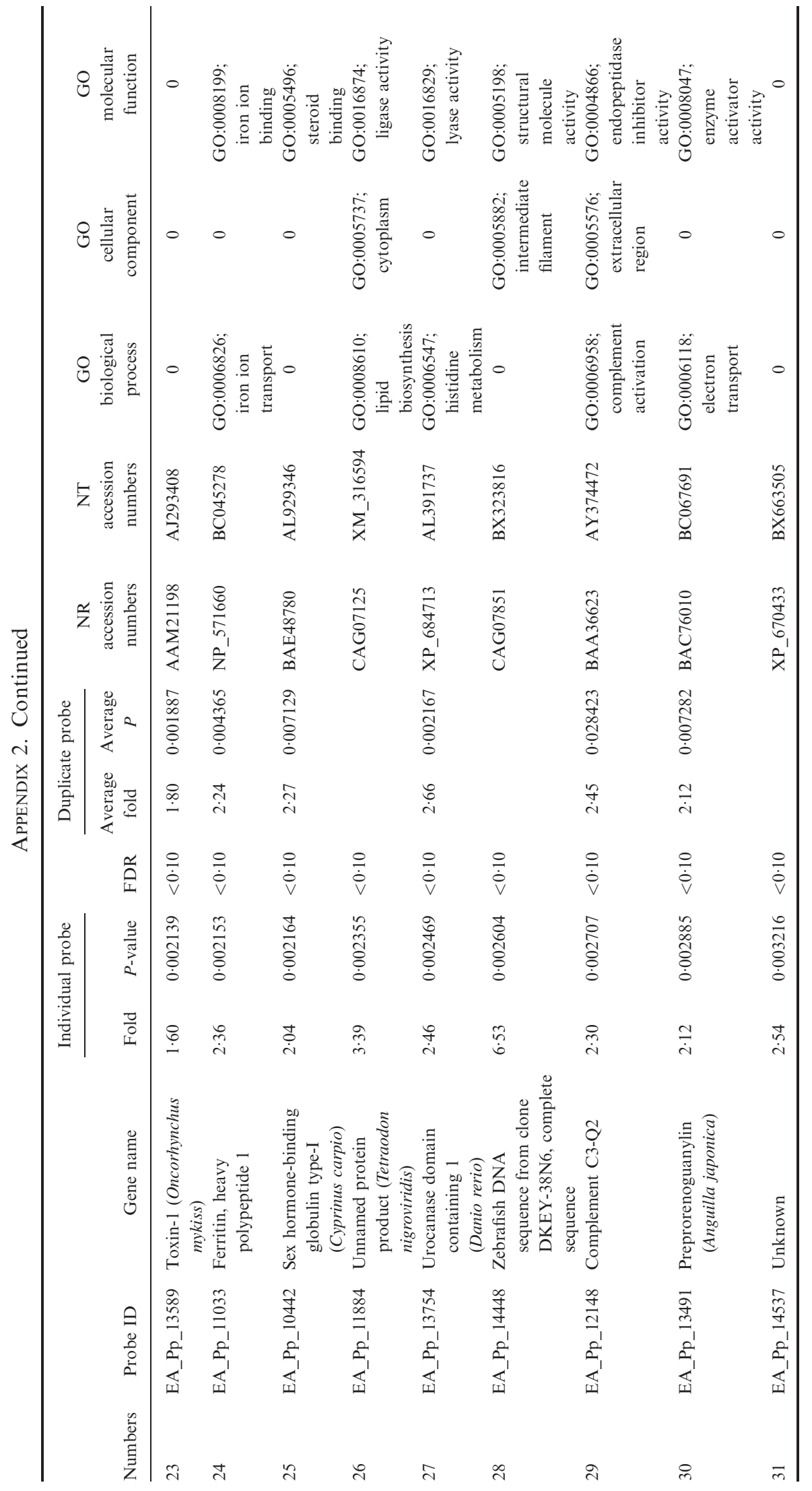




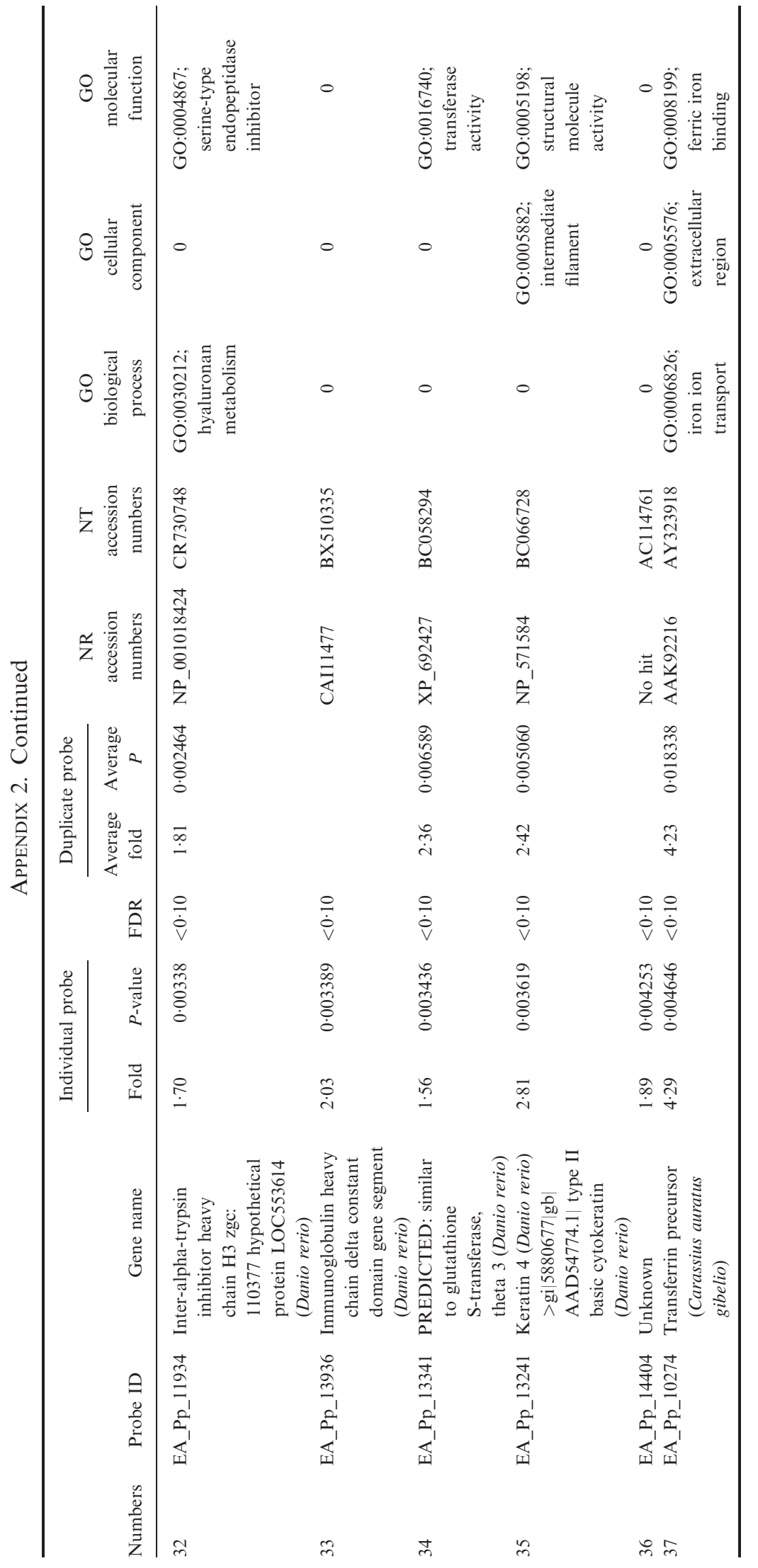




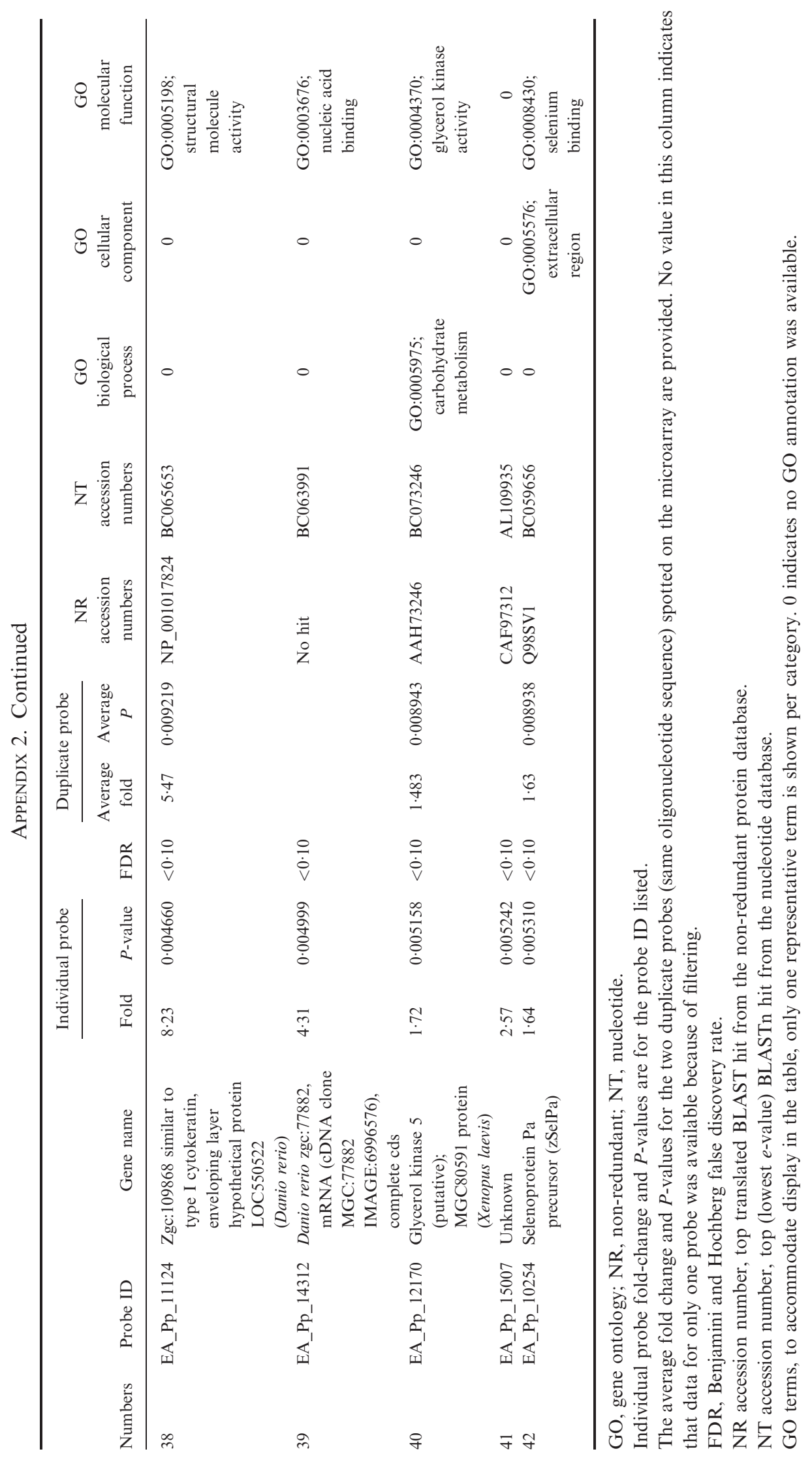




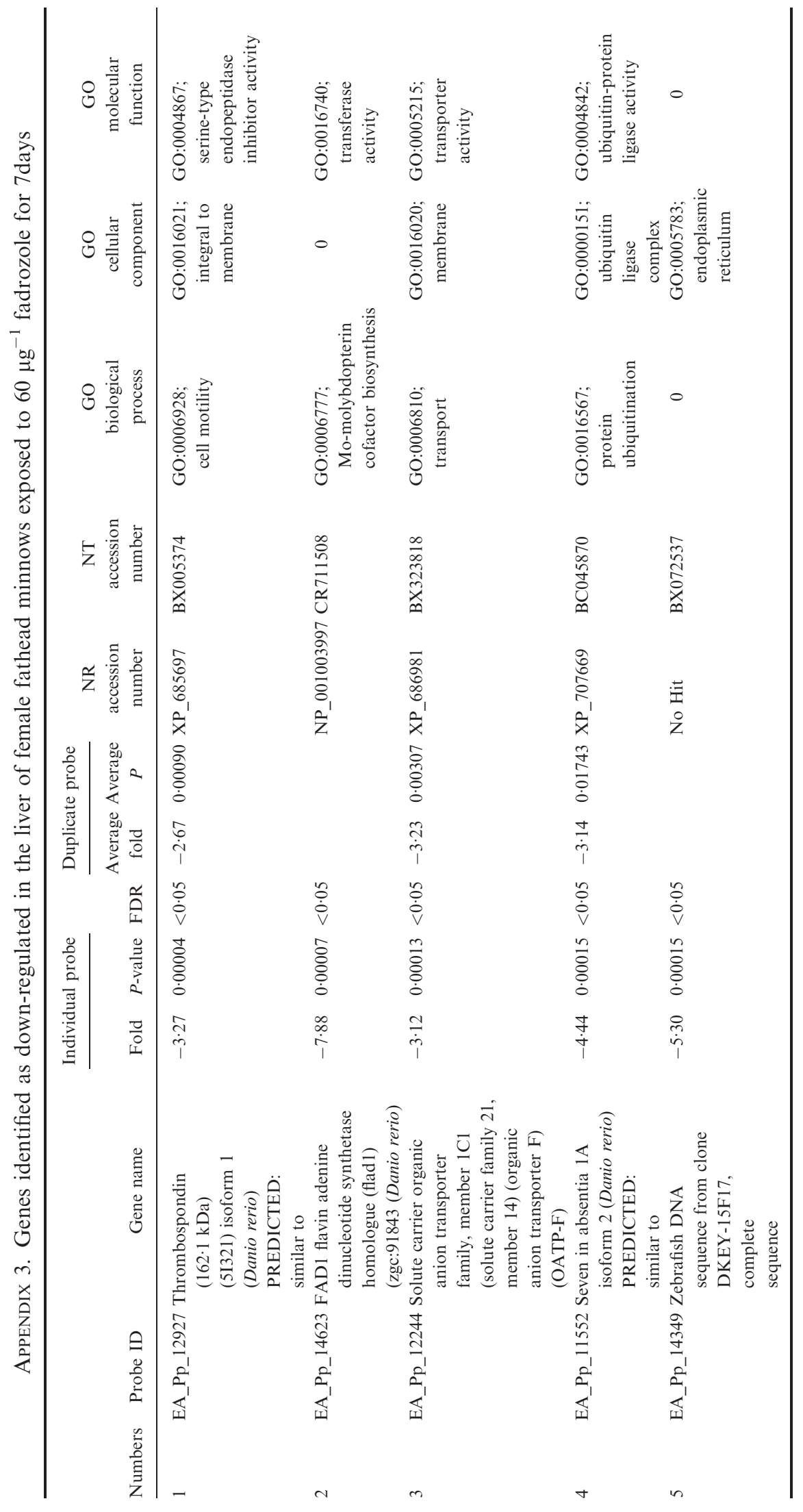




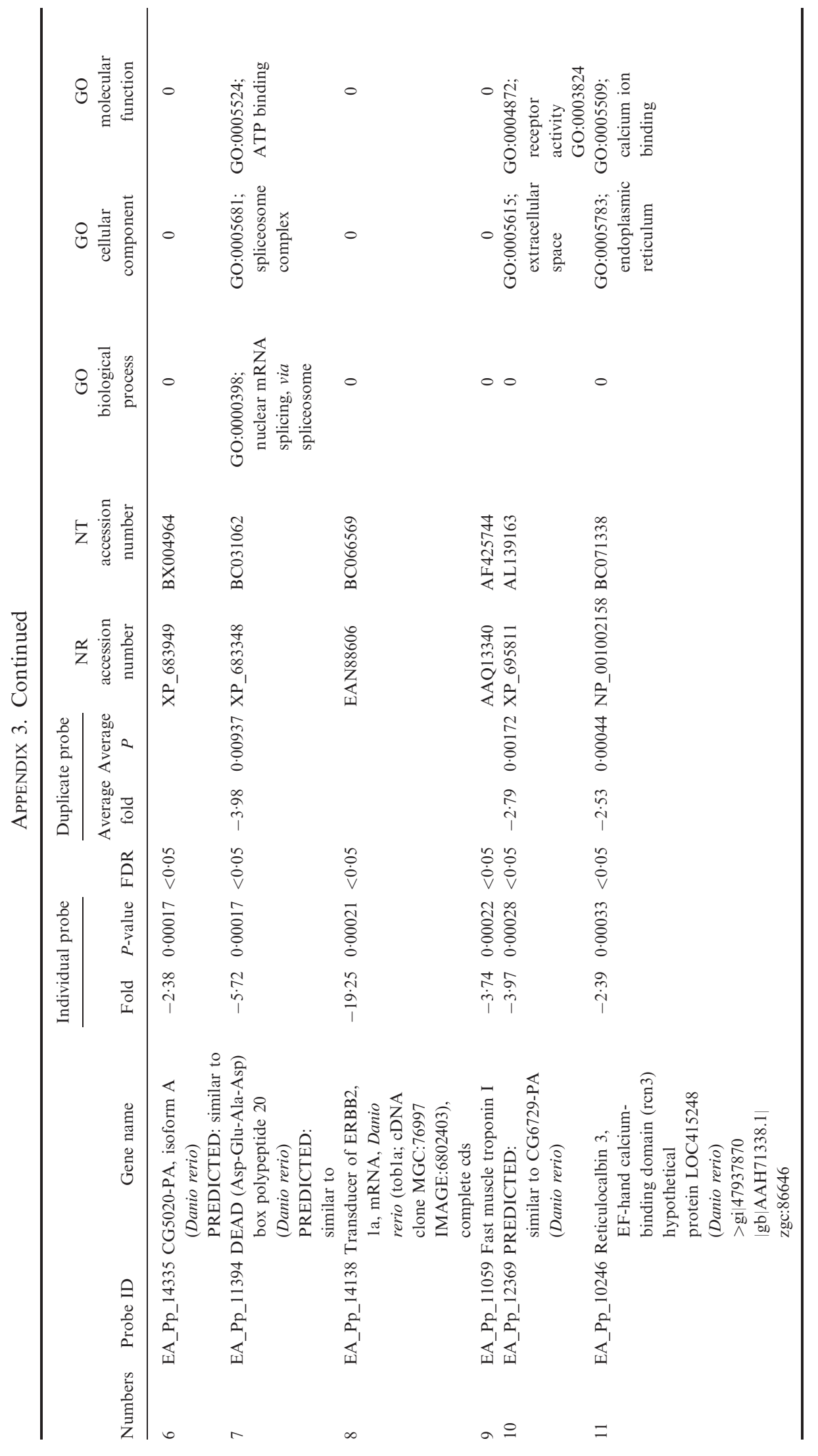




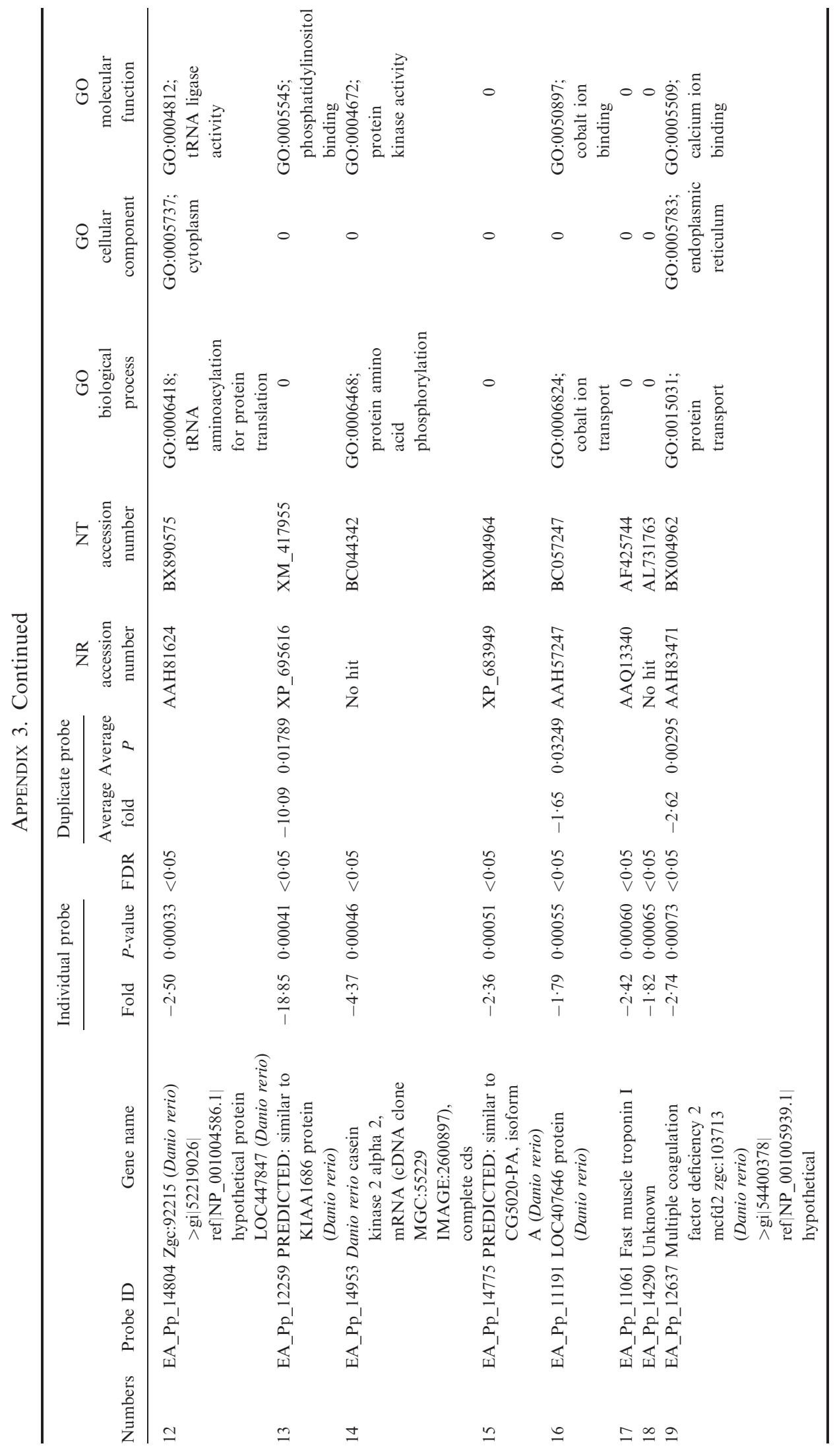




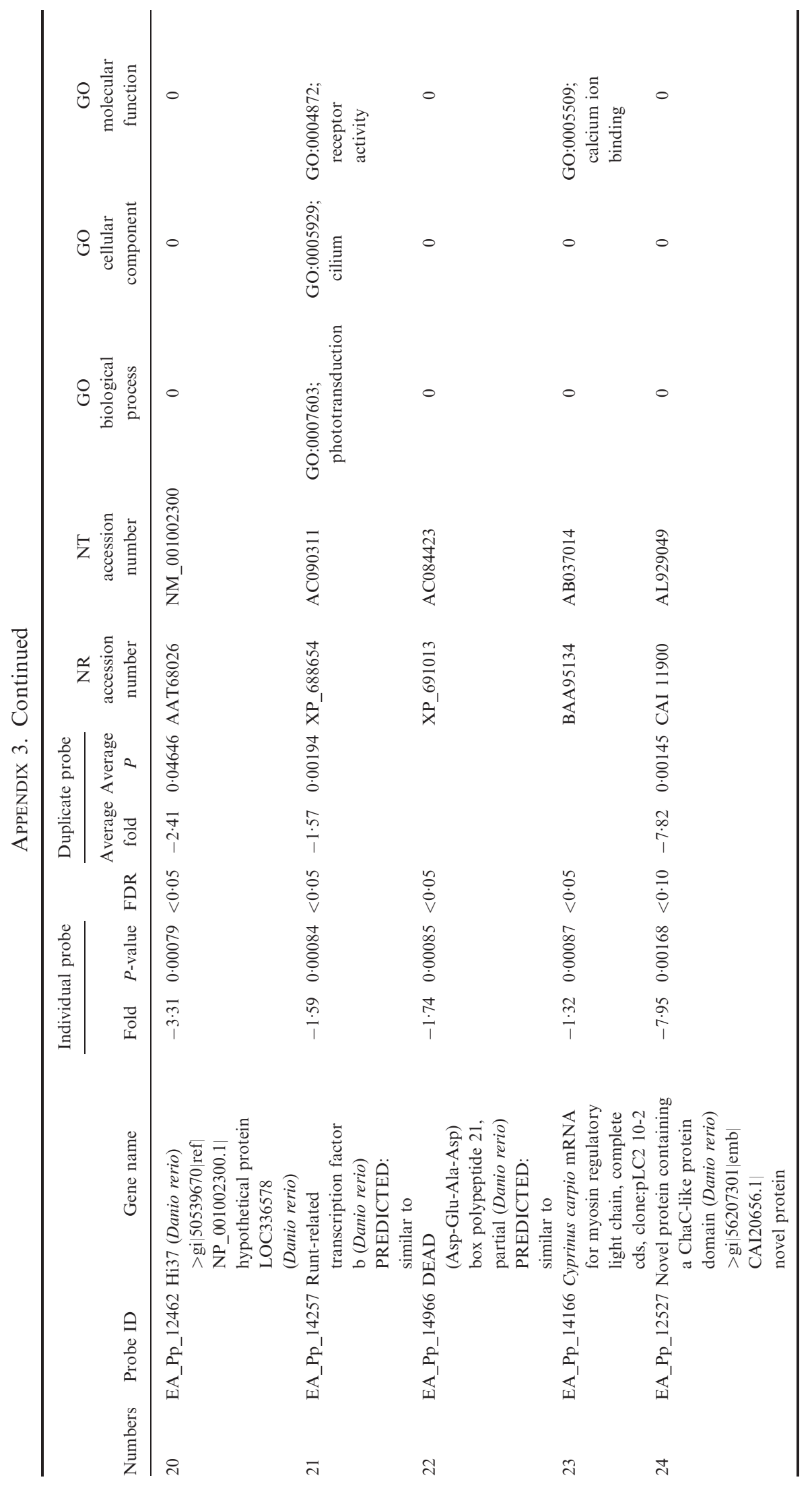




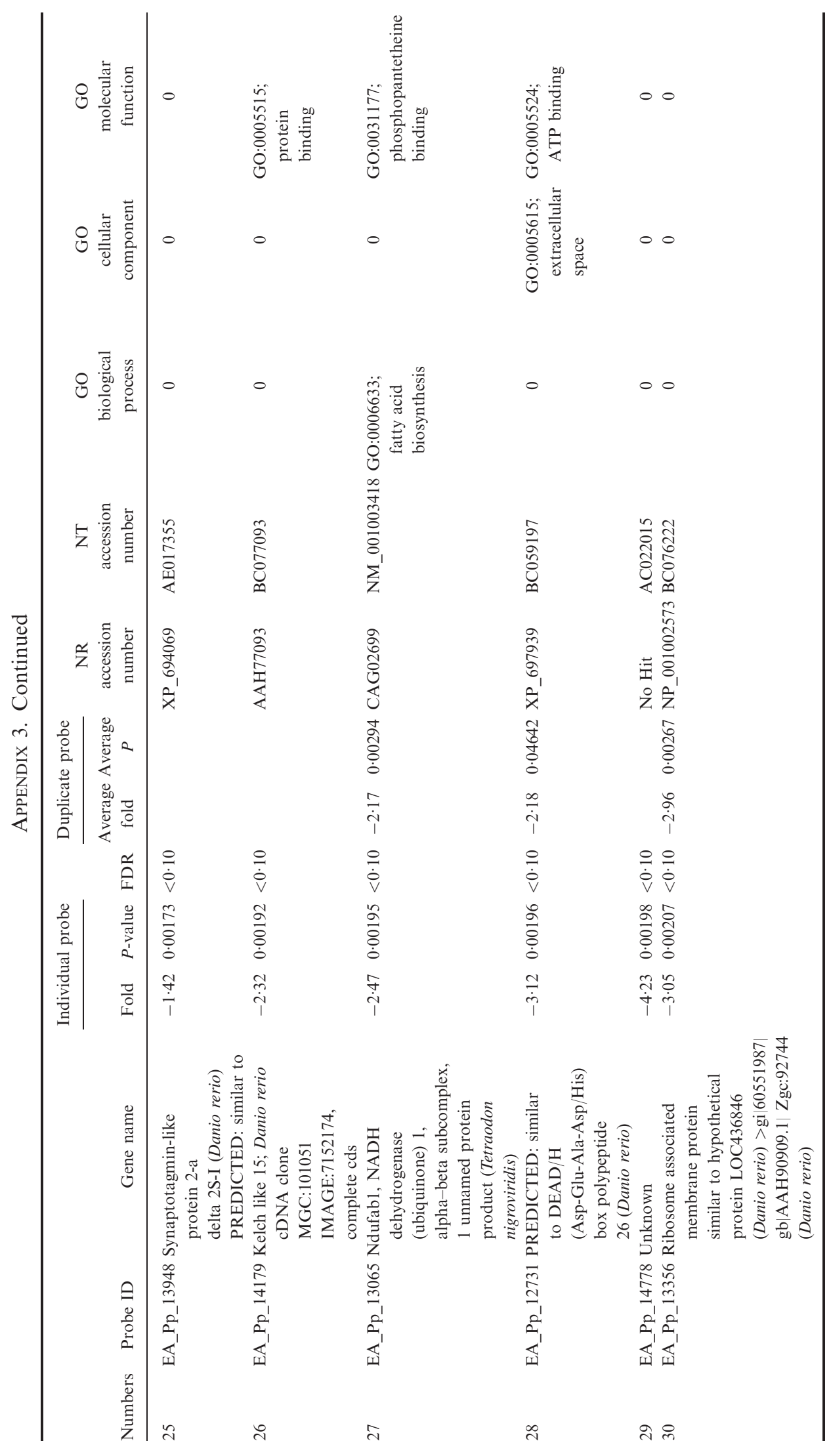




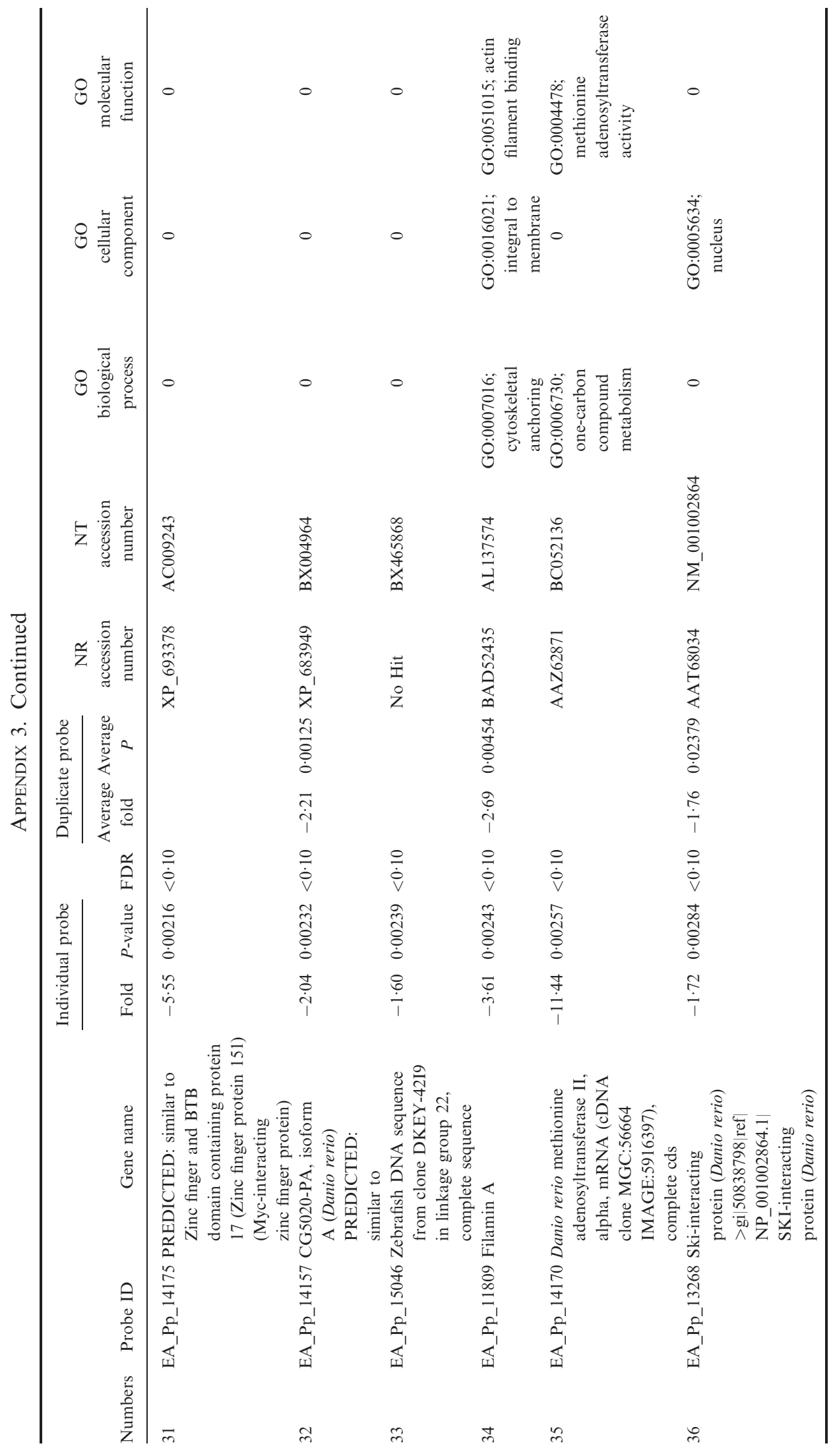




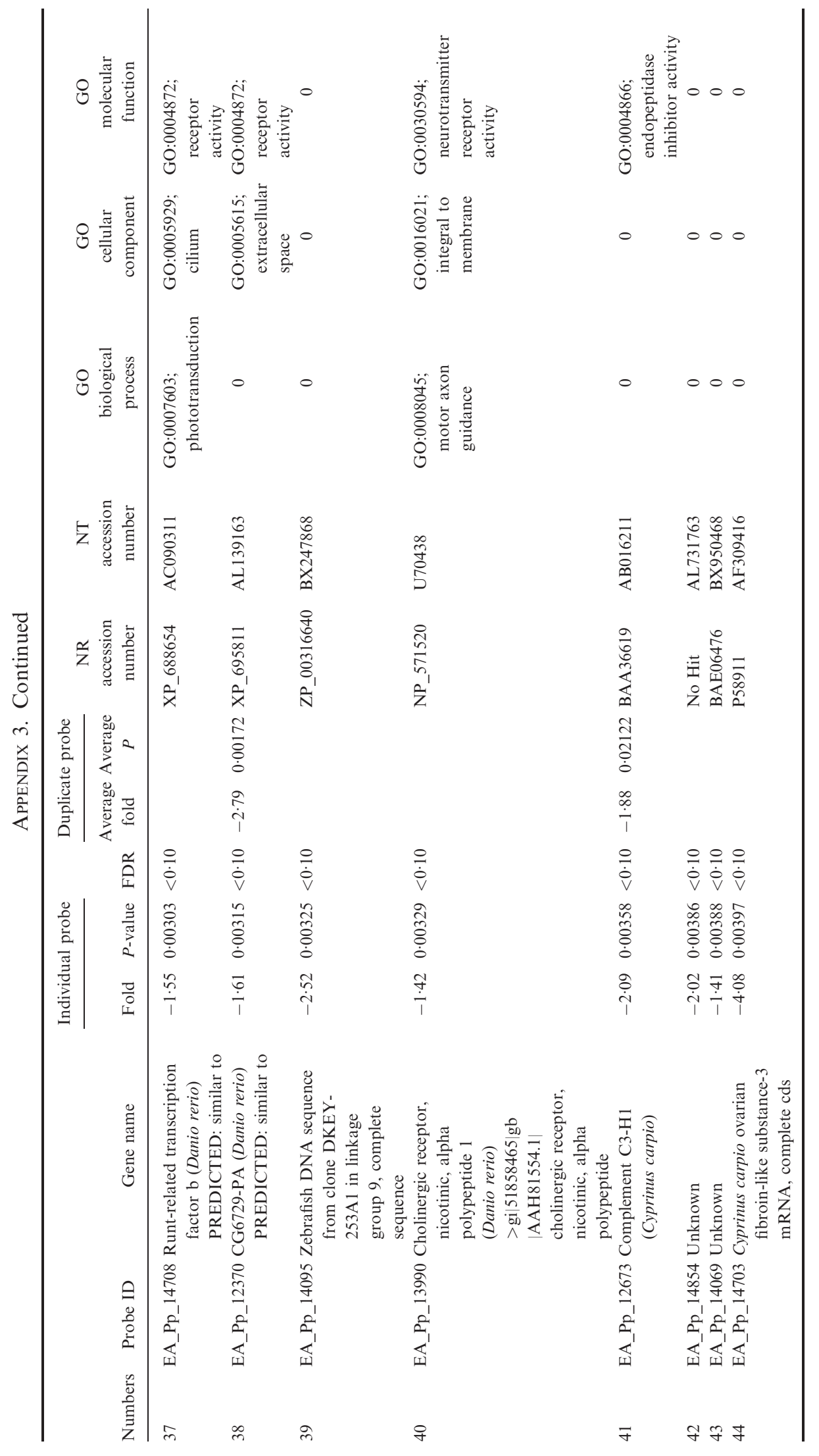




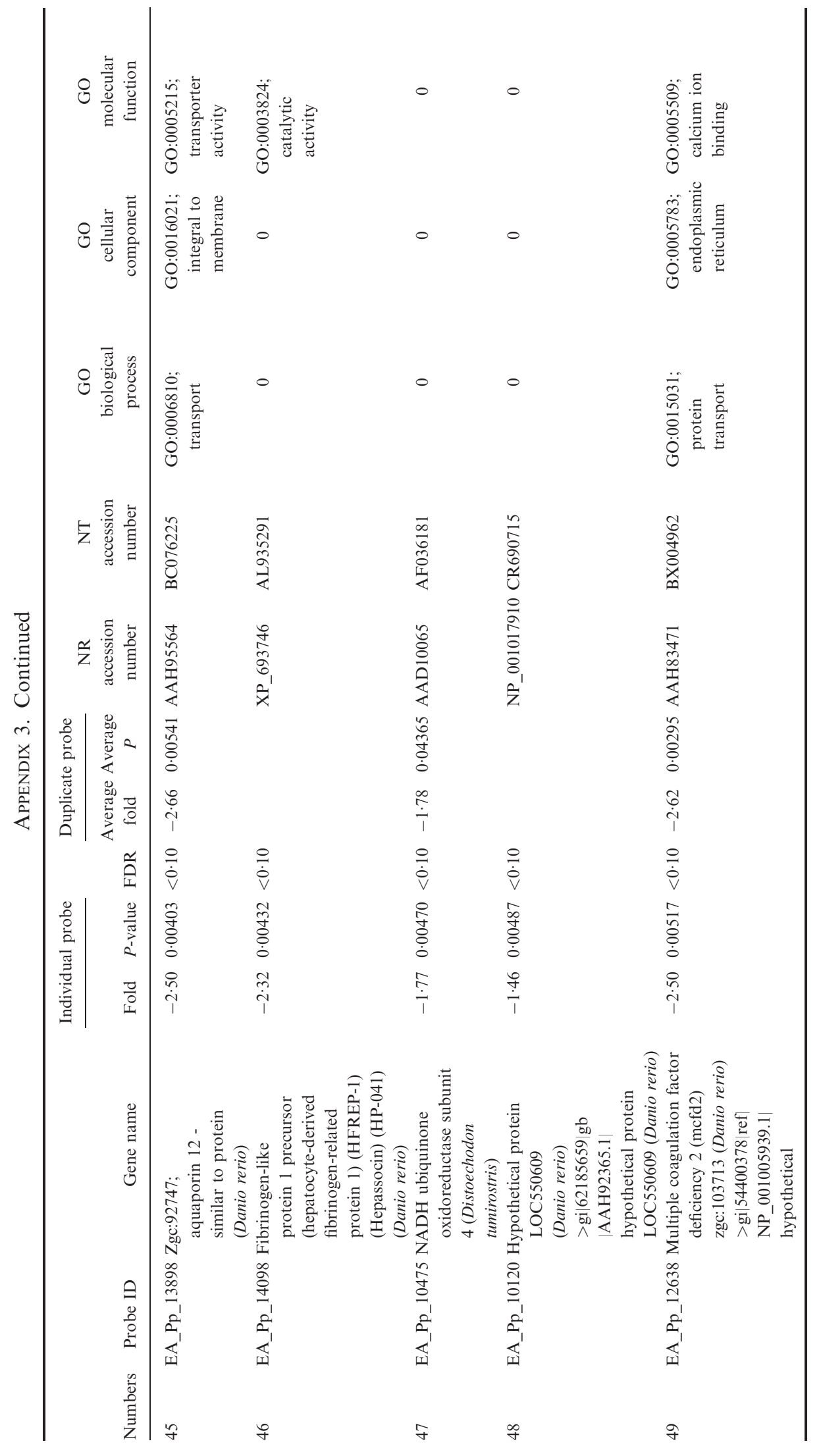




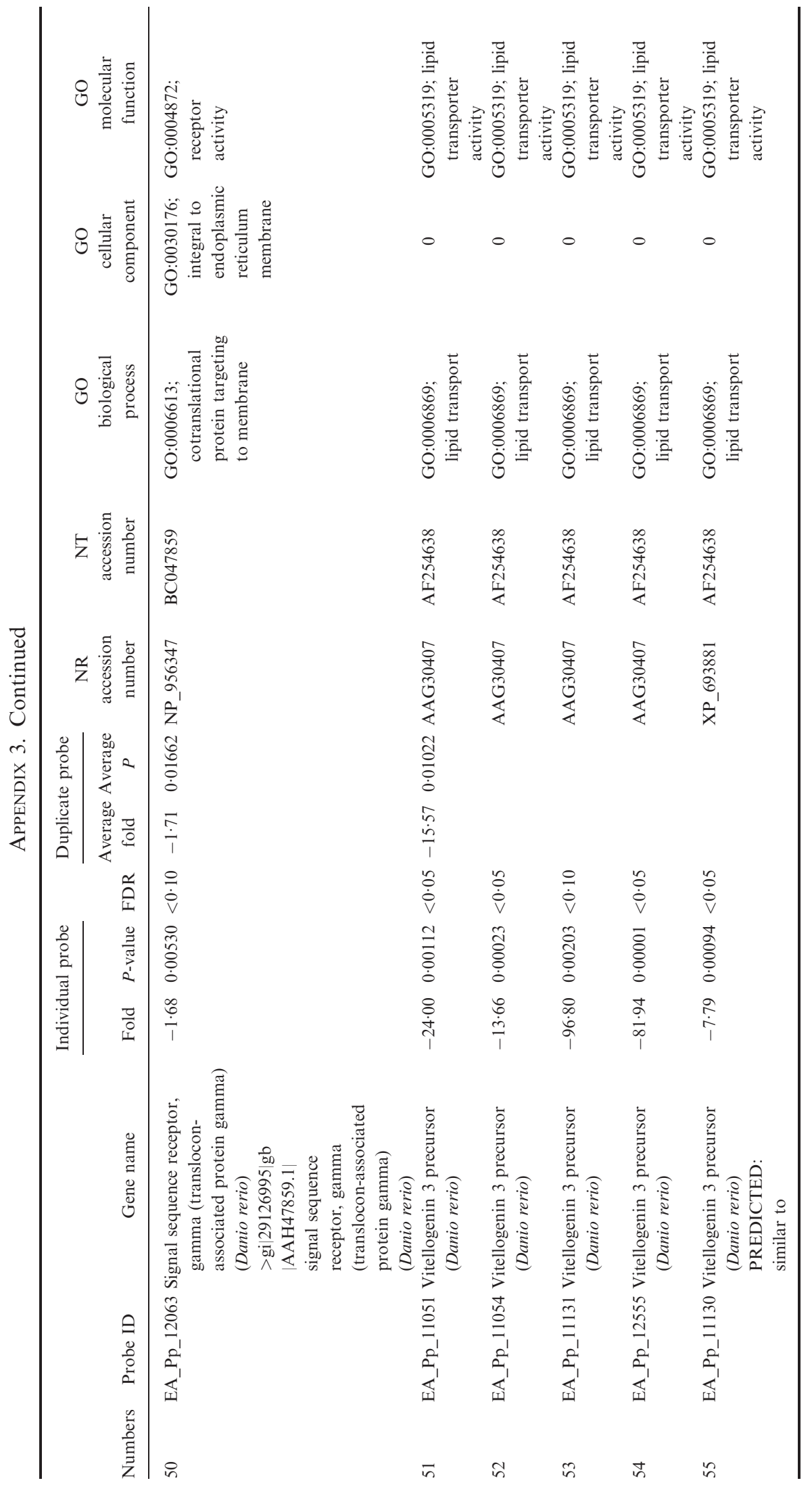




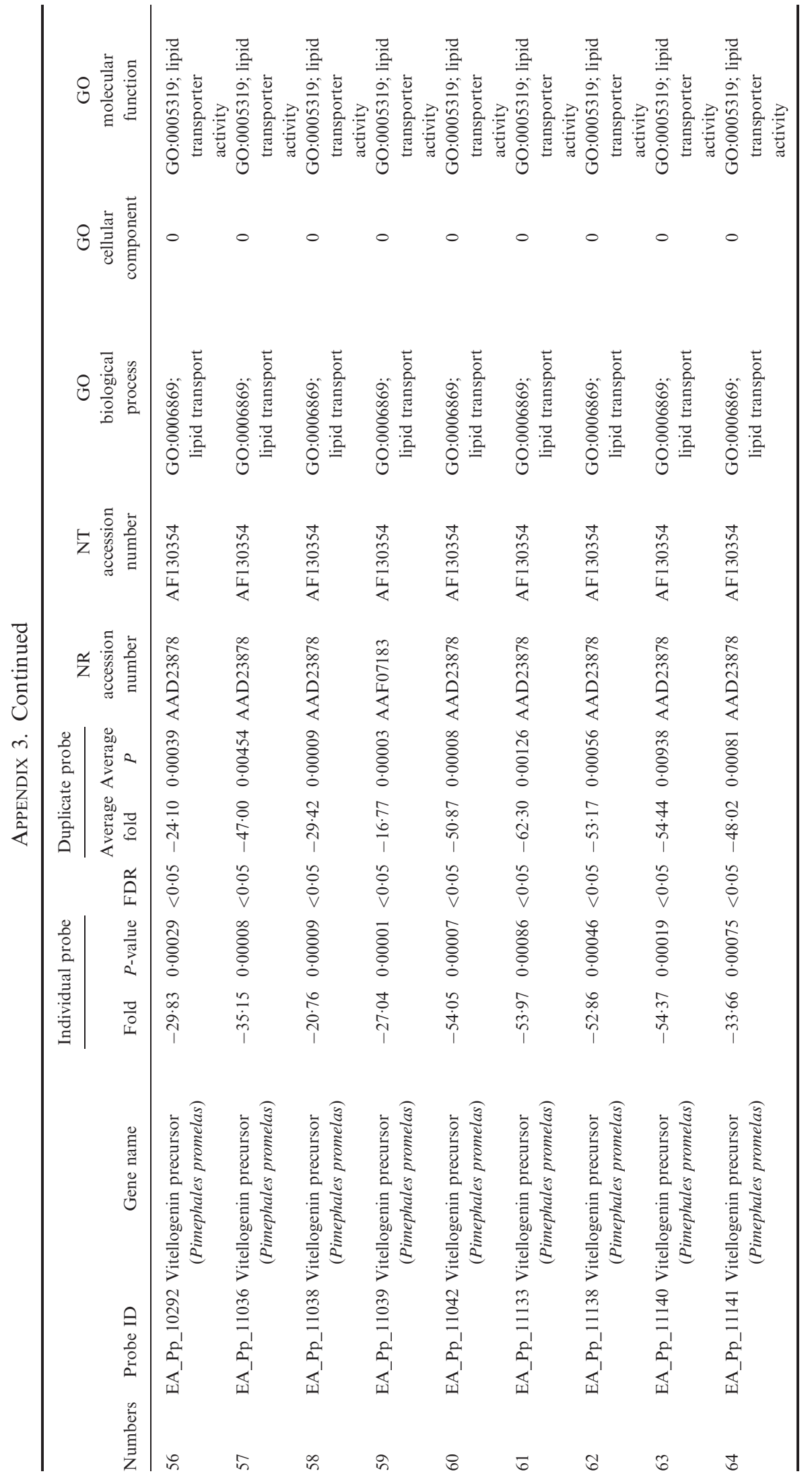




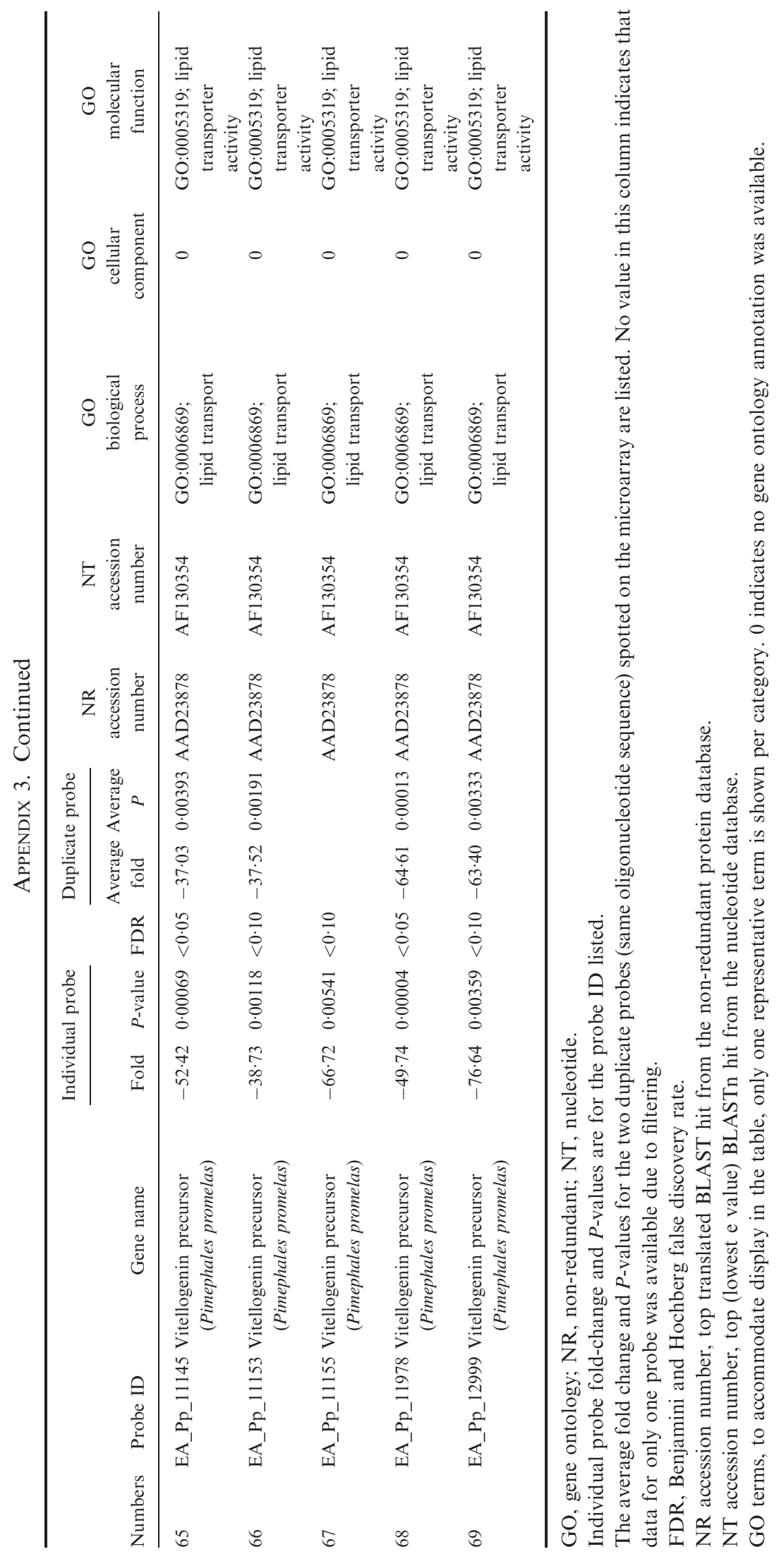


ApPENDIX 4. Expanded list of genes whose expression was potentially up-regulated in the brain of female fathead minnows exposed to $60 \mu \mathrm{g}^{-1}$ fadrozole for 7 days based on relaxed differential expression criteria $^{\mathrm{a}}$

\begin{tabular}{|c|c|}
\hline Probe ID & Gene name \\
\hline EA_Pp_12430 & 7-dehydrocholesterol reductase \\
\hline EA_Pp_10659 & Alpha-tubulin \\
\hline EA_Pp_11679 & Beta tubulin zgc:123194 \\
\hline EA_Pp_11687 & Cct 4 chaperonin-containing T-complex 4 protein \\
\hline EA_Pp_11616 & Chaperonin-containing TCP1, subunit 3 (gamma) \\
\hline EA_Pp_10565 & Ctsd (cathepsin D) protein \\
\hline EA_Pp_11608 & Cyclase-associated protein-1 \\
\hline EA_Pp_12322 & $\begin{array}{l}\text { Cytochrome P450 39A1 (Oxysterol 7-alpha-hydroxylase) } \\
\text { (hCYP39A1) (Danio rerio) }\end{array}$ \\
\hline EA_Pp_13324 & Cytochrome P450, family 51 (sterol 14 demethylase) \\
\hline EA_Pp_10090 & $\Delta-6$ fatty acyl desaturase (Cyprinus carpio) putative \\
\hline EA_Pp_13257 & $\begin{array}{l}\text { DnaJ homologue subfamily C member } 8 \text { unknown (Hsp 40) } \\
\text { (protein for IMAGE:7432353) }\end{array}$ \\
\hline EA_Pp_12665 & Eukaryotic translation initiation factor 3 , subunit 8 (Danio rerio) \\
\hline EA_Pp_12035 & $\begin{array}{l}\text { Farnesyl diphosphate synthase (farnesyl pyrophosphate synthe- } \\
\text { tase) }\end{array}$ \\
\hline EA_Pp_11675 & Fas-associated factor 1 \\
\hline EA_Pp_10951 & Glucose phosphate isomerase a \\
\hline EA_Pp_10849 & Heat shock cognate $70 \mathrm{kDa}$ protein (Carassius auratus gibelio) \\
\hline EA_Pp_11743 & $\begin{array}{l}\text { Heterogeneous nuclear ribonucleoprotein } \mathrm{C}(\mathrm{C} 1 / \mathrm{C} 2) \text { zgc:55733 } \\
\text { similar to (Danio rerio) }\end{array}$ \\
\hline EA_Pp_11204 & Hsp90b protein (Danio rerio) \\
\hline EA_Pp_12933 & $\begin{array}{l}\text { KDEL (Lys-Asp-Glu-Leu) endoplasmic reticulum protein reten- } \\
\text { tion receptor } 3 \text { (Danio rerio) }\end{array}$ \\
\hline EA_Pp_11382 & $\begin{array}{l}\text { Kinesin-like protein (KIF1C) XP_697372 (Danio rerio) } \\
\text { PREDICTED: hypothetical protein }\end{array}$ \\
\hline EA_Pp_12239 & $\begin{array}{l}\text { Ras-related C3 botulinum toxin substrate (rho family, small GTP } \\
\text { binding protien) unknown }\end{array}$ \\
\hline EA_Pp_10854 & S-adenosylhomocysteine hydrolase (ahcy) \\
\hline EA_Pp_11058 & Titin-like \\
\hline EA_Pp_12874 & Tropomyosin 3 \\
\hline EA_Pp_11984 & $\begin{array}{l}\text { Tubulin, alpha } 1 \text { (Strongylocentrotus purpuratus) PREDICTED: } \\
\text { similar to }\end{array}$ \\
\hline EA_Pp_11955 & Tubulin, alpha 8 like (tuba81) tubulin, alpha 8 like (Danio rerio) \\
\hline EA_Pp_12384 & $\begin{array}{l}\text { (StARD12) (START domain-containing protein 12) (Danio rerio) } \\
\text { Rho-GTPase-activating }\end{array}$ \\
\hline EA_Pp_12198 & ATPase type 13A2 (Danio rerio) PREDICTED: similar to \\
\hline EA_Pp_10525 & Beta tubulin \\
\hline EA_Pp_12516 & cAMP-regulated phosphoprotein 19 \\
\hline EA_Pp_10880 & Chaperonin containing TCP1, subunit $6 \mathrm{~A}$ (zeta 1 ) \\
\hline EA_Pp_11415 & Chaperonin containing TCP1, subunit 7 (eta) \\
\hline EA_Pp_11399 & COBW domain-containing protein zgc: 77617 \\
\hline EA_Pp_10385 & Cyclin G1 \\
\hline EA_Pp_14181 & Diphosphomevalonate decarboxylase zgc:100824 (Danio rerio) \\
\hline
\end{tabular}


Appendix 4. Continued

\begin{tabular}{|c|c|}
\hline Probe ID & Gene name \\
\hline EA_Pp_12111 & $\begin{array}{l}\text { DNA replication licensing factor MCM6 (Mis5 homologue) } \\
\text { (Danio rerio) PREDICTED: }\end{array}$ \\
\hline EA_Pp_10540 & $\begin{array}{l}\text { Elongation of very long chain fatty acids protein } 2 \text { (Danio rerio) } \\
\text { PREDICTED: similar to }\end{array}$ \\
\hline EA_Pp_12507 & Epoxide hydrolase 1, microsomal (xenobiotic) \\
\hline EA_Pp_11396 & $\begin{array}{l}\text { Eukaryotic translation initiation factor } 3 \text {, subunit } 6 \text { interacting } \\
\text { protein }\end{array}$ \\
\hline EA_Pp_10158 & Glutamic acid decarboxylase isoform 65 \\
\hline EA_Pp_12005 & $\begin{array}{l}\text { Guanine nucleotide-binding protein } \mathrm{G}(\mathrm{i}) \text {, alpha-2 subunit } \\
\text { (adenylate cyclase-inhibiting } \mathrm{G} \text { ) }\end{array}$ \\
\hline EA_Pp_11899 & $\mathrm{H} 3$ histone, family $3 \mathrm{~A}$ \\
\hline EA_Pp_14944 & $\begin{array}{l}\text { HLCS gene for holocarboxylase synthetase, complete cds Homo } \\
\text { sapiens }\end{array}$ \\
\hline EA_Pp_10858 & Insulin-like growth factor binding protein 2 \\
\hline EA_Pp_10371 & $\begin{array}{l}\text { Lanosterol synthase (oxidosqualene-lanosterol cyclase) } \\
\text { (2,3-epoxysqualene-lanosterol) }\end{array}$ \\
\hline EA_Pp_11222 & Myosin IXB (Danio rerio) PREDICTED: similar to \\
\hline EA_Pp_11555 & Nucleosome assembly protein 1 , like 1 \\
\hline EA_Pp_12575 & Peptidase D \\
\hline EA_Pp_11389 & Potassium channel tetramerization domain containing 10 \\
\hline EA_Pp_10979 & Proteasome (prosome, macropain) 26S subunit, non-ATPase, 3 \\
\hline EA_Pp_10934 & $\begin{array}{l}\text { Protein phosphatase } 1 \text { regulatory subunit } 7 \text { zgc: } 123325 \\
\text { hypothetical protein LOC } 560323\end{array}$ \\
\hline EA_Pp_11255 & $\begin{array}{l}\text { Solute carrier family } 37 \text { (glycerol-3-phosphate transporter), } \\
\text { member } 3 \text { (Gallus gallus) }\end{array}$ \\
\hline EA_Pp_14436 & $\begin{array}{l}\text { Solute carrier family } 4 \text { member } 11 \text {, sodium bicarbonate trans- } \\
\quad \text { porter XP_687848 (Danio rerio) }\end{array}$ \\
\hline EA_Pp_11443 & Thioredoxin domain containing (Txndc) protein (Danio rerio) \\
\hline EA_Pp_12947 & $\begin{array}{l}\text { Translation elongation factor } 1 \text { epsilon-1 (multisynthetase } \\
\text { complex auxiliary component) }\end{array}$ \\
\hline EA_Pp_11362 & $\begin{array}{l}\text { Ubiquitin-specific protease } 14 \text { (tRNA-guanine transglycosylase) } \\
\text { ubiquitin-specific protease }\end{array}$ \\
\hline EA_Pp_10377 & $\begin{array}{l}\text { Ubiquitin-conjugating enzyme E2D } 3 \text { (Danio rerio) } \\
>\text { gi }|29124433| \mathrm{gb} \mid \text { AAH } 48896.1 \mid\end{array}$ \\
\hline EA_Pp_14021 & $\begin{array}{l}\text { Zebrafish DNA sequence from clone DKEY-31N5, complete } \\
\text { sequence }\end{array}$ \\
\hline EA_Pp_12157 & Zgc: 100785 \\
\hline EA_Pp_11412 & $\begin{array}{l}\text { Zgc:112031 hypothetical protein LOC550364 (Danio rerio) } \\
\quad>\text { gi| } 62202639|\mathrm{gb}| \text { AAH93166.1| }\end{array}$ \\
\hline EA_Pp_11722 & Zgc:85809 \\
\hline
\end{tabular}

${ }^{\mathrm{a}}$-test $P$-value for a single probe $<0 \cdot 05$, no conflicting fold change data for duplicate or multiple probes. 
ApPENDIX 5. Expanded list of genes whose expression was potentially up-regulated in the liver of female fathead minnows exposed to $60 \mu \mathrm{g} \mathrm{1^{-1 }}$ fadrozole for 7 days based on relaxed differential expression criteria ${ }^{a}$

\begin{tabular}{|c|c|}
\hline Probe ID & Gene name \\
\hline EA_Pp_14382 & (Calcitonin) activity modifying protein 2 isoform 2 (Danio rerio) \\
\hline EA_Pp_10293 & $14 \mathrm{kDa}$ apolipoprotein \\
\hline EA_Pp_15112 & $\begin{array}{l}\text { 16S ribosomal RNA gene Plasmodiophora brassicae, partial } \\
\text { sequence; mitochondrial gene for }\end{array}$ \\
\hline EA_Pp_10680 & 3-oxoacid CoA transferase 1 \\
\hline EA_Pp_13871 & $\begin{array}{l}\text { AAA ATPase containing von Willebrand factor type A (vWA) } \\
\text { domain (Magnetococcus sp. MC-1) }\end{array}$ \\
\hline EA_Pp_10993 & Actin, alpha, cardiac muscle like \\
\hline EA_Pp_13113 & $\begin{array}{l}\text { Adenylate kinase hypothetical protein LOC445486 (Danio rerio) } \\
>\text { gi }|51327295| \mathrm{gb} \mid \text { AAH80261.1| Zgc:91930 (Danio rerio) }\end{array}$ \\
\hline EA_Pp_15109 & $\begin{array}{l}\text { Adiponectin receptor } 2 \text { (ADIPOR2) novel protein similar to } \\
\quad \text { vertebrate (Danio rerio) }\end{array}$ \\
\hline EA_Pp_10702 & Alanine-glyoxylate aminotransferase \\
\hline EA_Pp_12505 & $\begin{array}{l}\text { Alanine-glyoxylate aminotransferase 2-like } 1 \text { isoform } 1 \text { hypo- } \\
\text { thetical protein MGC63486 (Danio rerio) }\end{array}$ \\
\hline EA_Pp_10554 & Alcohol dehydrogenase \\
\hline EA_Pp_10017 & Alcohol dehydrogenase 5 \\
\hline EA_Pp_10837 & Aldehyde dehydrogenase 1 family, member L2 (Danio rerio) \\
\hline EA_Pp_11323 & Aldehyde dehydrogenase 9 family, member A1 \\
\hline EA_Pp_10275 & $\begin{array}{l}\text { Alpha-1-microglobulin-bikunin hypothetical protein } \\
\text { LOC394093 precursor (Danio rerio) }\end{array}$ \\
\hline EA_Pp_11207 & Amiloride binding protein 1 (Danio rerio) \\
\hline EA_Pp_10546 & Angiopoietin-like-3 \\
\hline EA_Pp_10735 & $\begin{array}{l}\text { Apobec-1 complementation factor isoform } 1 \text { isoform } 2 \text { (Danio } \\
\text { rerio) PREDICTED: similar to }\end{array}$ \\
\hline EA_Pp_12974 & $\begin{array}{l}\text { Apolipoprotein } \mathrm{B} \text { (including } \mathrm{Ag}(\mathrm{x}) \text { antigen) (APOB)novel protein } \\
\text { similar to vertebrate (Danio rerio) }\end{array}$ \\
\hline EA_Pp_14362 & Apolipoprotein Eb Apoeb protein (Danio rerio) \\
\hline EA_Pp_10045 & $\begin{array}{l}\text { Apolipoprotein Eb, mRNA (cDNA clone MGC: } 77232 \\
\text { IMAGE:6963043), complete cds Danio rerio }\end{array}$ \\
\hline EA_Pp_11953 & Bbs2 Bardet-Biedl syndrome 2 protein \\
\hline EA_Pp_14477 & $\begin{array}{l}\text { Beta-microseminoprotein precursor (prostate secreted seminal } \\
\text { plasma protein) }\end{array}$ \\
\hline EA_Pp_14191 & $\begin{array}{l}\text { Bubblegum, Acyl-CoA synthetase, lipidosin }- \text { similar to } \\
\text { MGC53673 protein isoform } 1 \text { (Danio rerio) }\end{array}$ \\
\hline EA_Pp_10699 & $\mathrm{C} 1$ inhibitor, partial (Danio rerio) \\
\hline EA_Pp_10543 & Cadherin 1, epithelial \\
\hline EA_Pp_10746 & $\begin{array}{l}\text { Calcium-activated chloride channel (Danio rerio) PREDICTED: } \\
\text { similar to }\end{array}$ \\
\hline EA_Pp_13842 & $\begin{array}{l}\text { Carboxylesterase } 2 \text { isoform } 1 \text { (Danio rerio) PREDICTED: similar } \\
\text { to }\end{array}$ \\
\hline EA_Pp_10487 & Carp desaturase 2 (CDS2) \\
\hline EA_Pp_14596 & Carp DNA sequence from clone carpf-GC2H, complete sequence \\
\hline EA_Pp_11275 & Casein kinase 2 alpha 1 \\
\hline EA_Pp_11297 & Cbs centrosomins beautiful sister protein \\
\hline
\end{tabular}


Appendix 5. Continued

\begin{tabular}{|c|c|}
\hline Probe ID & Gene name \\
\hline EA_Pp_12984 & $\begin{array}{l}\mathrm{CCCH} \text { zinc finger protein } \mathrm{C} 3 \mathrm{H}-1 \text { (Danio rerio) PREDICTED: } \\
\text { similar to }\end{array}$ \\
\hline EA_Pp_10669 & Ceruloplasmin \\
\hline EA_Pp_12770 & $\begin{array}{l}\text { Chromobox homologue } 1 \text { (Danio rerio) } \\
\quad>\text { gi }|49902655| \mathrm{gb} \mid \text { AAH75782.1| Chromobox homologue } 1\end{array}$ \\
\hline EA_Pp_12763 & $\begin{array}{l}\text { Cold-inducible RNA-binding protein (Danio rerio) } \\
>\text { gi }|28856196| \mathrm{gb} \mid \text { AAH } 48027.1 \mid \text { Cold inducible }\end{array}$ \\
\hline EA_Pp_12010 & Collagen, type I, alpha 1 \\
\hline EA_Pp_12841 & Complement B/C2-A2 (Cyprinus carpio) \\
\hline EA_Pp_12182 & complement C3 \\
\hline EA_Pp_12512 & $\begin{array}{l}\text { Complement C3 precursor (HSE-MSF) (Danio rerio) } \\
\text { PREDICTED: similar to }\end{array}$ \\
\hline EA_Pp_10401 & $\begin{array}{l}\text { Complement C3-Q1, partial (Danio rerio) PREDICTED: similar } \\
\text { to }\end{array}$ \\
\hline EA_Pp_12148 & Complement C3-Q2 \\
\hline EA_Pp_10359 & Complement C3-S \\
\hline EA_Pp_12819 & Complement C4-2 (Cyprinus carpio) \\
\hline EA_Pp_13889 & Complement C4-2 (Danio rerio) PREDICTED: similar to \\
\hline EA_Pp_12899 & $\begin{array}{l}\text { Complement component } 8 \text { alpha polypeptide hypothetical } \\
\text { protein LOC445102 (Danio rerio) }\end{array}$ \\
\hline EA_Pp_10423 & Complement component 9 \\
\hline EA_Pp_10383 & Complement component $\mathrm{C} 9$ \\
\hline EA_Pp_11202 & Complement control protein factor I-A \\
\hline EA_Pp_10667 & Complement factor $\mathrm{B} / \mathrm{C} 2 \mathrm{~B}$ \\
\hline EA_Pp_11301 & Complement factor $\mathrm{B} / \mathrm{C} 2 \mathrm{~B}$ (Danio rerio) \\
\hline EA_Pp_13327 & $\begin{array}{l}\text { Complement factor } \mathrm{H} \text { zgc: } 123186 \text { unknown (protein for } \\
\text { MGC:123186) (Danio rerio) }\end{array}$ \\
\hline EA_Pp_13673 & $\begin{array}{l}\text { Cytochrome } c \text { oxidase subunit } 4 \text { hypothetical protein MGC73355 } \\
\text { (Danio rerio) }\end{array}$ \\
\hline EA_Pp_12321 & $\begin{array}{l}\text { Cytochrome P450 39A1 (Oxysterol 7-alpha-hydroxylase) (hCY- } \\
\text { P39A1) (Danio rerio) }\end{array}$ \\
\hline EA_Pp_10749 & Cytochrome P450 family 2, subfamily J zgc:91876 (Danio rerio) \\
\hline EA_Pp_10847 & Deiodinase, iodothyronine, type II \\
\hline EA_Pp_11767 & Dimethylanaline monooxygenase-like \\
\hline EA_Pp_12825 & $\begin{array}{l}\text { Enolase 1, (alpha) (Danio rerio) > gi }|47551317| \text { ref } \mid \text { NP_999888.1 } \mid \\
\text { enolase 3, (beta, muscle) (Danio rerio) }\end{array}$ \\
\hline EA_Pp_11405 & Eukaryotic translation initiation factor 3 , subunit 3 (gamma) \\
\hline EA_Pp_12231 & Eukaryotic translation initiation factor 3 , subunit 9 eta, $116 \mathrm{kDa}$ \\
\hline EA_Pp_12015 & Eukaryotic translation initiation factor $4 \mathrm{E}$ binding protein 3 \\
\hline EA_Pp_12740 & Expressed sequence AW548124 (Danio rerio) \\
\hline EA_Pp_12053 & F-box only protein 9 \\
\hline EA_Pp_10036 & F-box protein 38 isoform b (Danio rerio) \\
\hline EA_Pp_11033 & Ferritin, heavy polypeptide 1 \\
\hline EA_Pp_10711 & Fetuin long form \\
\hline EA_Pp_10698 & Fetuin-B \\
\hline EA_Pp_10856 & Fibronectin $1 b$ \\
\hline EA_Pp_11167 & Fibronectin variant 3 \\
\hline
\end{tabular}


Appendix 5. Continued

\begin{tabular}{|c|c|}
\hline Probe ID & Gene name \\
\hline EA_Pp_14585 & $\begin{array}{l}\text { FK } 506 \text { binding protein } 8 \text { hypothetical protein hypothetical } \\
\text { protein MGC77672 (Danio rerio) }\end{array}$ \\
\hline EA_Pp_13531 & Fructose-1,6-bisphosphatase (Esox lucius) \\
\hline EA_Pp_10587 & Fructose-1,6-bisphosphatase 1 \\
\hline EA_Pp_11851 & Fucosidase, alpha-L-1, tissue \\
\hline EA_Pp_10730 & $\begin{array}{l}\text { G protein pathway suppressor } 1 \text { isoform } 2 \text { isoform } 1 \text { (Danio rerio) } \\
\text { PREDICTED: similar to }\end{array}$ \\
\hline EA_Pp_12173 & $\begin{array}{l}\text { Gcat glycine C-acetyltransferase (2-amino-3-ketobutyrate- } \\
\text { coenzyme A ligase) LOC } 402822\end{array}$ \\
\hline EA_Pp_11044 & $\begin{array}{l}\text { Gliacolin (C1Q) novel protein similar to vertebrate (Danio rerio) } \\
>\text { gi } 68356446 \mid \text { ref } \mid \text { XP_708224.1| }\end{array}$ \\
\hline EA_Pp_10951 & Glucose phosphate isomerase a \\
\hline EA_Pp_10154 & Glucose-6-phosphate-1-dehydrogenase; G6PD \\
\hline EA_Pp_10752 & Glutamate dehydrogenase 1 \\
\hline EA_Pp_12885 & $\begin{array}{l}\text { Glutathione S-transferase, theta } 3 \text { (Danio rerio) PREDICTED: } \\
\text { similar to }\end{array}$ \\
\hline EA_Pp_10662 & $\begin{array}{l}\text { Glycogen phosphorylase hypothetical protein LOC493916 (Danio } \\
\text { rerio) }\end{array}$ \\
\hline EA_Pp_11899 & $\begin{array}{l}\text { H3 histone, family 3A (Mus musculus) } \\
\quad>\text { gi }|56388767| \mathrm{gb}|\mathrm{AAH} 87725.1| \mathrm{H} 3 \mathrm{f} 3 \mathrm{~b} \text { protein (Rattus norvegicus) }\end{array}$ \\
\hline EA_Pp_10367 & Hemopexin precursor (Danio rerio) PREDICTED: similar to \\
\hline EA_Pp_10839 & Hgd homogentisate 1,2-dioxygenase protein (Danio rerio) \\
\hline EA_Pp_13209 & $\begin{array}{l}\text { HIV-1 Rev binding protein, partial (Danio rerio) PREDICTED: } \\
\text { similar to }\end{array}$ \\
\hline EA_Pp_10485 & $\begin{array}{l}\text { Hyaluronic acid binding protein } 2 \text { isoform } 3 \text { (Danio rerio) } \\
\quad>\text { gi }|68370901| \text { ref } \mid \text { XP_686209.1| }\end{array}$ \\
\hline EA_Pp_10761 & $\begin{array}{l}\text { Hypothetical protein LOC406484 (Danio rerio) } \\
\text { >gi| }|47085999| \text { ref } \mid \text { NP_998368.1| hypothetical }\end{array}$ \\
\hline EA_Pp_12655 & $\begin{array}{l}\text { Hypothetical protein LŌC554105 (Danio rerio) } \\
>\text { gi|66773128|ref|NP_001019577.1| hypothetical }\end{array}$ \\
\hline EA_Pp_12032 & Hypoxia-inducible factor-1alpha (Ctenopharyngodon idella) \\
\hline EA_Pp_13936 & $\begin{array}{l}\text { Immunoglobulin heavy chain delta constant domain gene } \\
\text { segment (Danio rerio) }\end{array}$ \\
\hline EA_Pp_10857 & $\begin{array}{l}\text { Insulin-like growth factor binding protein } 2 \text { Igfbp } 2 \text { protein } \\
\text { (Danio rerio) }\end{array}$ \\
\hline EA_Pp_11180 & $\begin{array}{l}\text { Inter-alpha trypsin inhibitor (similar to) hypothetical protein } \\
\text { LOC402873 (Danio rerio) }\end{array}$ \\
\hline EA_Pp_11212 & $\begin{array}{l}\text { Inter-alpha (globulin) inhibitor H2 novel protein (zgc:56119) } \\
\text { (Danio rerio) }\end{array}$ \\
\hline EA_Pp_11933 & $\begin{array}{l}\text { Inter-alpha-trypsin inhibitor heavy chain } 3 \text { hypothetical protein } \\
\text { LOC553614 (Danio rerio) }\end{array}$ \\
\hline EA_Pp_10678 & $\begin{array}{l}\text { Intestinal fatty acid binding protein } 2 \text { (Danio rerio) } \\
>\text { gi }|6687439| \text { emb } \mid \text { CAB } 64945.1 \mid \text { intestinal fatty }\end{array}$ \\
\hline EA_Pp_11124 & $\begin{array}{l}\text { Keratin (similar to) hypothetical protein LOC550522 (Danio } \\
\text { rerio) > gi|62205109|gb|AAH92718.1| }\end{array}$ \\
\hline EA_Pp_13241 & $\begin{array}{l}\text { Keratin } 4 \text { (Danio rerio) }>\text { gi }|5880677| \text { gb } \mid \text { AAD } 54774.1 \mid \text { type II } \\
\text { basic cytokeratin }(\text { Danio rerio })\end{array}$ \\
\hline
\end{tabular}


Appendix 5. Continued

\begin{tabular}{|c|c|}
\hline Probe ID & Gene name \\
\hline EA_Pp_13461 & $\begin{array}{l}\text { Kininogen } 1 \text { zgc: } 103569 \text { (Danio rerio) } \\
\quad>\text { gi| } 54400464 \mid \text { ref } \mid \text { NP_001005981.1| hypothetical protein }\end{array}$ \\
\hline EA_Pp_10831 & $\begin{array}{l}\text { Lecithin cholesterol acyltransferase (Gallus gallus) } \\
\text { PREDICTED: similar to }\end{array}$ \\
\hline EA_Pp_10591 & LOC322493 (Danio rerio) PREDICTED: hypothetical protein \\
\hline EA_Pp_10895 & Lysophospholipase 3 Lypla3 protein (Danio rerio) \\
\hline EA_Pp_13999 & Megalobrama amblycephala beta-actin gene, complete cds \\
\hline EA_Pp_12169 & MGC80591 protein (Xenopus laevis) \\
\hline EA_Pp_11705 & $\begin{array}{l}\text { Minichromosome maintenance protein } 8 \text { isoform 1; DNA repli- } \\
\text { cation licensing factor MCM8; chromosome } 20 \text { open reading } \\
\text { frame } 154 \text { (Gallus gallus) PREDICTED: similar to }\end{array}$ \\
\hline EA_Pp_11333 & $\begin{array}{l}\text { Mitochondrial ribosomal protein S5 isoform } 2 \text { (Danio rerio) } \\
\quad>\text { gi| } 68387293 \mid \text { ref } \mid \text { XP_708293.1| }\end{array}$ \\
\hline EA_Pp_12791 & $\begin{array}{l}\text { Multiple inositol polyphosphate histidine phosphatase } 1 \\
\text { (Danio rerio) PREDICTED: similar to }\end{array}$ \\
\hline EA_Pp_11489 & $\begin{array}{l}\text { MYST histone acetyltransferase } 2 \text { (Danio rerio) } \\
>\text { gi }|28279513| \text { gb } \mid \text { AAH } 45314.1 \mid \text { MYST histone }\end{array}$ \\
\hline EA_Pp_12596 & Novel protein (Danio rerio) \\
\hline EA_Pp_10983 & Nucleolar protein 5A NOP56 (Danio rerio) \\
\hline EA_Pp_11103 & Opsin 1 (cone pigments), medium-wave-sensitive, 1 (Danio rerio) \\
\hline EA_Pp_13595 & $\begin{array}{l}\text { PDZ and LIM domain 2, isoform } 2 \text { (Homo sapiens) } \\
>\text { gi| }|47940543| \mathrm{gb}|\mathrm{AAH} 71774.1| \text { PDZ and LIM }\end{array}$ \\
\hline EA_Pp_13543 & Pentraxin (Salmo salar) \\
\hline EA_Pp_11807 & $\begin{array}{l}\text { Peroxisomal membrane protein } 2 \text { Zgc:92599 (Danio rerio) } \\
\quad>\text { gi }|52219060| \text { ref } \mid \text { NP_001004607.1| }\end{array}$ \\
\hline EA_Pp_12330 & $\begin{array}{l}\text { Phosphoenolpyruvate carboxykinase (Danio rerio) } \\
\quad>\text { gi|39645931 }|\mathrm{gb}| \text { AAH63985.1| Zgc:77867 }\end{array}$ \\
\hline EA_Pp_12276 & Phosphoenolpyruvate carboxylase (Erythroculter ilishaeformis) \\
\hline EA_Pp_10564 & $\begin{array}{l}\text { Phosphoglucomutase } 1 \text { (Danio rerio) } \\
\quad \text { gi }|41056111| \text { ref } \mid N_{-} \text {. } 957319.1 \mid \text { phosphoglucomutase } 1 \text { (Danio } \\
\text { rerio) }\end{array}$ \\
\hline EA_Pp_10494 & $\begin{array}{l}\text { Phospholipid hydroperoxide glutathione peroxidase A (Danio } \\
\text { rerio) }\end{array}$ \\
\hline EA_Pp_10593 & $\begin{array}{l}\text { Plasminogen (Danio rerio) }>\text { gi }|41393105| \text { ref } \mid \text { NP_958880.1 } \mid \\
\text { plasminogen (Danio rerio) }\end{array}$ \\
\hline EA_Pp_10236 & Poly(A) polymerase (Carassius auratus) \\
\hline EA_Pp_12297 & $\begin{array}{l}\text { PREDICTED: similar to cadherin 1, epithelial, partial (Danio } \\
\text { rerio) }\end{array}$ \\
\hline EA_Pp_11662 & $\begin{array}{l}\text { Receptor accessory protein } 3 \text { (reep3) hypothetical protein } \\
\text { MGC55529 (Danio rerio) }\end{array}$ \\
\hline EA_Pp_10251 & $\begin{array}{l}\text { Retinol binding protein 4, plasma (Danio rerio) } \\
>\text { gi }|6687453| \mathrm{emb} \mid \text { CAB64947.1| retinol binding }\end{array}$ \\
\hline EA_Pp_12264 & Rev-Erb beta 2 (Danio rerio) \\
\hline EA_Pp_15074 & Reverse transcriptase (Danio rerio) \\
\hline EA_Pp_14251 & $\begin{array}{l}\text { Ring finger protein } 128 \mathrm{zgc:} 77843 \text {, mRNA (cDNA clone } \\
\text { MGC:77843 IMAGE:7002238), complete }\end{array}$ \\
\hline EA_Pp_12526 & RNA (guanine-7-) methyltransferase (Danio rerio) \\
\hline
\end{tabular}


Appendix 5. Continued

\begin{tabular}{|c|c|}
\hline Probe ID & Gene name \\
\hline EA_Pp_12302 & Sck isoform 1 (Danio rerio) \\
\hline EA_Pp_10253 & Selenoprotein $\mathrm{Pa}$ precursor $(\mathrm{zSelPa})$ \\
\hline EA_Pp_11322 & Serine hydroxymethyltransferase $1 \mathrm{Shmt} 1$ protein (Danio rerio) \\
\hline EA_Pp_10441 & Sex hormone-binding globulin type-I (Cyprinus carpio) \\
\hline EA_Pp_14066 & $\begin{array}{l}\text { SH3 and multiple ankyrin repeat domains } 2 \text { isoform 1, partial } \\
\text { (Danio rerio) PREDICTED: }\end{array}$ \\
\hline EA_Pp_13481 & $\begin{array}{l}\text { Signal transducer and activator of transcription } 1 \text { isoform beta } \\
\text { (Danio rerio) PREDICTED: similar to }\end{array}$ \\
\hline EA_Pp_11658 & $\begin{array}{l}\text { Solute carrier family } 1 \text { (glial high affinity glutamate transporter), } \\
\text { member } 3 \text { (Danio rerio) }\end{array}$ \\
\hline EA_Pp_10684 & $\begin{array}{l}\text { Solute carrier family } 35 \text { (UDP-glucuronic acid-UDP-N-acetyl- } \\
\text { galactosamine dual transporter) }\end{array}$ \\
\hline EA_Pp_13563 & Toxin-1 (Oncorhynchus mykiss) \\
\hline EA_Pp_13621 & $\begin{array}{l}\text { Transcobalamin I precursor (TCI) (TC I) (Danio rerio) } \\
\text { PREDICTED: similar to }\end{array}$ \\
\hline EA_Pp_11015 & Transferrin (Ctenopharyngodon idella) \\
\hline EA_Pp_14023 & Transferrin mRNA, complete cds Ctenopharyngodon idella \\
\hline EA_Pp_14843 & Transferrin precursor (Carassius auratus gibelio) \\
\hline EA_Pp_13381 & Transferrin variant A (Cyprinus carpio) \\
\hline EA_Pp_14267 & Transferrin variant A mRNA, complete cds Cyprinus carpio \\
\hline EA_Pp_11821 & Transferrin variant A1 (Carassius auratus) \\
\hline EA_Pp_11012 & Transferrin variant D (Carassius auratus gibelio) \\
\hline EA_Pp_14012 & Ubiquitin-like protein 2 mRNA, complete cds Carassius auratus \\
\hline EA_Pp_10741 & Uncoupling protein 1 (Cyprinus carpio) \\
\hline EA_Pp_11466 & $\begin{array}{l}\text { Unnamed protein product (Oryctolagus cuniculus) } \\
>\text { gi }|129336| \mathrm{sp}|\mathrm{P} 11611| \mathrm{P} 2 \mathrm{AB} \text { RABIT }\end{array}$ \\
\hline EA_Pp_12143 & $\begin{array}{l}\text { Urate oxidase (uricase) zgc: } 92 \overline{4} 14 \text { (Danio rerio) } \\
\quad>\text { gi }|50539724| \text { ref } \mid \text { NP_001002332.1| hypothetical }\end{array}$ \\
\hline EA_Pp_10348 & Ureidopropionase, beta \\
\hline EA_Pp_13753 & $\begin{array}{l}\text { Urocanase domain containing } 1 \text { (Danio rerio) PREDICTED: } \\
\text { similar to }\end{array}$ \\
\hline EA_Pp_13963 & $\begin{array}{l}\text { Vertebrate KIN, antigenic determinant of recA protein homo- } \\
\text { logue (mouse) (KIN) (Danio rerio) }\end{array}$ \\
\hline EA_Pp_10567 & Vitronectin (Vtn) protein (Danio rerio) \\
\hline EA_Pp_14866 & $\begin{array}{l}\text { Zebrafish DNA sequence from clone } \mathrm{CH} 211-233 \mathrm{E} 16 \text { in linkage } \\
\text { group 16, complete sequence }\end{array}$ \\
\hline EA_Pp_14892 & $\begin{array}{l}\text { Zebrafish DNA sequence from clone } \mathrm{CH} 211-260 \mathrm{P} 9 \text { in linkage } \\
\text { group } 18 \text {, complete sequence }\end{array}$ \\
\hline EA_Pp_15125 & $\begin{array}{l}\text { Zebrafish DNA sequence from clone } \mathrm{CH} 211-63 \mathrm{O} 20 \text { in linkage } \\
\text { group 20, complete sequence }\end{array}$ \\
\hline EA_Pp_14204 & $\begin{array}{l}\text { Zebrafish DNA sequence from clone DKEY-117N4, complete } \\
\text { sequence }\end{array}$ \\
\hline EA_Pp_14448 & $\begin{array}{l}\text { Zebrafish DNA sequence from clone DKEY-38N6, complete } \\
\text { sequence }\end{array}$ \\
\hline EA_Pp_10893 & $\begin{array}{l}\text { Zgc:55468 hypothetical protein MGC55468 (Danio rerio) } \\
\quad>\text { gi| } 41055857 \mid \text { ref } \mid \text { NP_956451.1| }\end{array}$ \\
\hline
\end{tabular}


ApPendix 5. Continued

\begin{tabular}{|c|c|}
\hline Probe ID & Gene name \\
\hline EA_Pp_11927 & $\begin{array}{l}\text { Zgc:55908 hypothetical protein MGC55908 (Danio rerio) } \\
\text { >gi|41055722|ref|NP_956477.1| }\end{array}$ \\
\hline EA_Pp_10777 & $\begin{array}{l}\text { Zgc:64076 (Danio rerio) }>\text { gi| } 47085915 \mid \text { ref } \mid \text { NP_998315.1| hypo- } \\
\text { thetical protein LOC406424 (Danio rerio) }\end{array}$ \\
\hline EA_Pp_12034 & $\begin{array}{l}\text { Zgc:77348 (Danio rerio) }>\text { gi }|47085735| \text { ref } \mid \text { NP_998128.1| hypo- } \\
\text { thetical protein LOC405899 (Danio rerio) }\end{array}$ \\
\hline EA_Pp_14312 & $\begin{array}{l}\text { Zgc: } 77882, \text { mRNA (cDNA clone MGC:77882 IMAGE:6996576), } \\
\text { complete cds Danio rerio }\end{array}$ \\
\hline
\end{tabular}

${ }^{\mathrm{a}} t$-test $P$-value for a single probe $<0 \cdot 05$, no conflicting fold change data for duplicate or multiple probes.

APPENDix 6. Expanded list of genes whose expression was potentially up-regulated in the liver of female fathead minnows exposed to $60 \mu \mathrm{g}^{-1}$ fadrozole for 7 days, based on relaxed differential expression criteria $^{a}$

\begin{tabular}{|c|c|}
\hline Probe ID & Gene name \\
\hline EA_Pp_13716 & 40 S ribosomal protein S24 (Pagrus major) \\
\hline EA_Pp_10374 & 40S ribosomal protein S24-like protein \\
\hline EA_Pp_11299 & $\begin{array}{l}\text { Apolipoprotein A-I binding protein zgc:92263 (Danio rerio) } \\
\text { >gi|50540304|ref|NP_001002618.1| }\end{array}$ \\
\hline EA_Pp_13897 & Aquaporin similar to $\overline{\mathrm{ggc}}: 92747$ protein (Danio rerio) \\
\hline EA_Pp_12725 & $\begin{array}{l}\text { Beta-carotene } 15,15 \text {-dioxygenase } 2 \text { (bcdo2) (Danio rerio) } \\
\quad>\text { gi }|13872742| \mathrm{emb} \mid \text { CAC } 37567.1 \mid\end{array}$ \\
\hline EA_Pp_11353 & BING4-like (WD repeat domain 46) \\
\hline EA_Pp_10245 & $\begin{array}{l}\text { Calumenin (similar to -isoform unclear) hypothetical protein } \\
\text { LOC415248 (Danio rerio) }\end{array}$ \\
\hline EA_Pp_13751 & Cdc211 cell division control 2 like 1 protein (Mus musculus) \\
\hline EA_Pp_12265 & $\begin{array}{l}\text { Cyclic nucleotide gated channel beta } 1 \text { (Danio rerio) } \\
\quad>\text { gi| } 68365256 \mid \text { ref } \mid \text { XP_684092.1| }\end{array}$ \\
\hline EA_Pp_11996 & $\begin{array}{l}\text { Cytochrome P450, family } 3 \text {, subfamily a, polypeptide } 13 \text { (Danio } \\
\text { rerio) }\end{array}$ \\
\hline EA_Pp_11393 & DEAD (Asp-Glu-Ala-Asp) box polypeptide 20 (Danio rerio) \\
\hline EA_Pp_10539 & $\begin{array}{l}\text { Elongation of very long chain fatty acids protein } 2 \text { (Danio rerio) } \\
\text { PREDICTED: similar to }\end{array}$ \\
\hline EA_Pp_10102 & Eukaryotic translation elongation factor 1 gamma \\
\hline EA_Pp_11059 & Fast muscle troponin I \\
\hline EA_Pp_11809 & Filamin A \\
\hline EA_Pp_14896 & $\begin{array}{l}\text { Glutamate-ammonia ligase (glutamine synthase) b, mRNA } \\
\text { (cDNA clone MGC:56052 }\end{array}$ \\
\hline EA_Pp_10168 & $\begin{array}{l}\text { Heat shock protein 90-beta (Danio rerio) } \\
\quad>\text { gi }|2791863| \mathrm{gb} \mid \text { AAB } 96969.1 \mid \text { heat shock protein }\end{array}$ \\
\hline EA_Pp_12579 & $\begin{array}{l}\text { Huntingtin-interacting protein K (Danio rerio) PREDICTED: } \\
\text { similar to }\end{array}$ \\
\hline
\end{tabular}


Appendix 6. Continued

\begin{tabular}{|c|c|}
\hline Probe ID & Gene name \\
\hline EA_Pp_12422 & Hypothetical protein LOC549556 (Xenopus tropicalis) \\
\hline EA_Pp_11391 & $\begin{array}{l}\text { Lectin mannose-binding } 1 \text { (similar to) LOC } 559775 \text { protein (Danio } \\
\text { rerio) }\end{array}$ \\
\hline EA_Pp_12637 & Multiple coagulation factor deficiency 2 zgc:103713 (Danio rerio) \\
\hline EA_Pp_10219 & NADH ubiquinone oxidoreductase subunit 4 (Abbottina rivularis) \\
\hline EA_Pp_10475 & $\begin{array}{l}\text { NADH ubiquinone oxidoreductase subunit } 4 \text { (Distoechodon } \\
\text { tumirostris) }\end{array}$ \\
\hline EA_Pp_11620 & $\begin{array}{l}\text { Natural killer specific antigen Klip (similar to) hypothetical } \\
\text { protein LOC334511 (Danio rerio) }\end{array}$ \\
\hline EA_Pp_12527 & $\begin{array}{l}\text { Novel protein containing a ChaC-like protein domain (Danio } \\
\text { rerio) }\end{array}$ \\
\hline EA_Pp_12487 & $\begin{array}{l}\text { Nucleobindin } 2 \mathrm{~b} \text { (Danio rerio })>\text { gi }|41393115| \text { ref } \mid \text { NP_}_{-} 958887.1 \mid \\
\text { nucleobindin } 2 b(\text { Danio rerio })\end{array}$ \\
\hline EA_Pp_13297 & $\begin{array}{l}\text { Ovulatory protein-2 precursor (Danio rerio) PREDICTED: } \\
\text { similar to }\end{array}$ \\
\hline EA_Pp_11135 & $\begin{array}{l}\text { Parvalbumin (Danio rerio) }>\text { gi }|62204541| \mathrm{gb}|\mathrm{AAH} 93135.1| \\
\text { Parvalbumin like (Danio rerio) }\end{array}$ \\
\hline EA_Pp_14257 & $\begin{array}{l}\text { PREDICTED: similar to runt-related transcription factor } \\
\text { b (Danio rerio) }\end{array}$ \\
\hline EA_Pp_13483 & Rho guanine nucleotide exchange factor 5 isoform 1 (Danio rerio) \\
\hline EA_Pp_13281 & Ribosomal protein L14 (Danio rerio) \\
\hline EA_Pp_12097 & $\begin{array}{l}\text { Ribosomal protein L18 (60S) Zgc:92872 (Danio rerio) } \\
\quad>\text { gi| } 51010947 \mid \text { ref } \mid \text { NP_001003432.1| }\end{array}$ \\
\hline EA_Pp_13526 & $\begin{array}{l}\text { Ribosomal protein S23 (Rattus norvegicus) PREDICTED: similar } \\
\text { to }\end{array}$ \\
\hline EA_Pp_13903 & $\begin{array}{l}\text { Ribosomal protein S25 hypothetical protein MGC73391 (Danio } \\
\text { rerio) }\end{array}$ \\
\hline EA_Pp_13353 & $\begin{array}{l}\text { Ribosome associated membrane protein } 4 \text { hypothetical protein } \\
\text { LOC436846 (Danio rerio) }\end{array}$ \\
\hline EA_Pp_12305 & Sb:cb283 protein (Danio rerio) \\
\hline EA_Pp_11551 & $\begin{array}{l}\text { Seven in absentia 1A isoform } 2 \text { (Danio rerio) PREDICTED: } \\
\text { similar to }\end{array}$ \\
\hline EA_Pp_12063 & $\begin{array}{l}\text { Signal sequence receptor, gamma (ssr3) (translocon-associated } \\
\text { protein gamma) (Danio rerio) }\end{array}$ \\
\hline EA_Pp_12189 & Solute carrier family 41, member 1 isoform 1 (Danio rerio) \\
\hline EA_Pp_12243 & $\begin{array}{l}\text { Solute carrier organic anion transporter family, member } 1 \mathrm{C} 1 \\
\quad \text { (solute carrier family } 21 \text { ) }\end{array}$ \\
\hline EA_Pp_13654 & $\begin{array}{l}\text { Testis nuclear RNA-binding protein (Danio rerio) PREDICTED: } \\
\text { similar to }\end{array}$ \\
\hline EA_Pp_12927 & $\begin{array}{l}\text { Thrombospondin ( } 162.1 \mathrm{kDa} \text { ) ( } 5 \mathrm{I} 321) \text { isoform } 1 \text { (Danio rerio) } \\
\text { PREDICTED: similar to }\end{array}$ \\
\hline EA_Pp_10268 & $\begin{array}{l}\text { Tnfrsf1a-associated via death domain (Danio rerio) } \\
>\text { gi }|18859509| \text { ref } \mid \text { NP_571682.1| tnfrsfla- }\end{array}$ \\
\hline EA_Pp_11191 & Transcobalamin II precursor LOC407646 protein (Danio rerio) \\
\hline EA_Pp_12215 & $\begin{array}{l}\text { Transmembrane protein } 49 \text { (Danio rerio) } \\
\quad>\text { gi }|46309489| \text { ref } \mid \text { NP_ } 996943.1 \mid \text { transmembrane }\end{array}$ \\
\hline
\end{tabular}


Appendix 6. Continued

\begin{tabular}{|c|c|}
\hline Probe ID & Gene name \\
\hline EA_Pp_10387 & $\begin{array}{l}\text { Tryptophan 2,3 dioxygenase MGC107895 protein isoform } 1 \\
\text { (Danio rerio) PREDICTED: }\end{array}$ \\
\hline EA_Pp_13035 & Unknown (Homo sapiens) \\
\hline EA_Pp_13527 & Vitellogenin 3 precursor (Danio rerio) \\
\hline EA_Pp_11130 & Vitellogenin 3 precursor (Danio rerio) PREDICTED: similar to \\
\hline EA_Pp_11977 & Vitellogenin precursor (Pimephales promelas) \\
\hline EA_Pp_15046 & $\begin{array}{l}\text { Zebrafish DNA sequence from clone DKEY-42I9 in linkage } \\
\text { group 22, complete sequence }\end{array}$ \\
\hline EA_Pp_14039 & $\begin{array}{l}\text { Zinc finger and BTB domain containing protein } 17 \text { (Zinc finger } \\
\text { protein } 151 \text { ) (Myc-interacting) }\end{array}$ \\
\hline EA_Pp_10293 & $14 \mathrm{kDa}$ apolipoprotein \\
\hline EA_Pp_13862 & $\begin{array}{l}\text { Actin filament associated protein hypothetical protein } \\
\text { LOC566757 (Danio rerio) }\end{array}$ \\
\hline EA_Pp_11759 & Alas2 protein aminolevulinate synthase \\
\hline EA_Pp_12876 & $\begin{array}{l}\text { Alpha-2-macroglobulin-1 isoform } 14 \text { (Danio rerio) } \\
\text { PREDICTED: similar to }\end{array}$ \\
\hline EA_Pp_12014 & Anaphase promoting complex subunit 5 \\
\hline EA_Pp_12974 & $\begin{array}{l}\text { Apolipoprotein } \mathrm{B} \text { (including } \mathrm{Ag}(\mathrm{x}) \text { antigen) (APOB)novel protein } \\
\text { similar to vertebrate (Danio rerio) }\end{array}$ \\
\hline EA_Pp_14672 & $\begin{array}{l}\text { Arginase, type II (ARG2) mRNA, complete cds Danio rerio clone } \\
\text { RK126A3H11 }\end{array}$ \\
\hline EA_Pp_12822 & $\begin{array}{l}\text { Barrier to autointegration factor (similar to) zgc: } 77767 \text { hypo- } \\
\text { thetical protein LOC } 334717\end{array}$ \\
\hline EA_Pp_12482 & BCL2-adenovirus E1b $19 \mathrm{kDa}$ interacting protein $3 \mathrm{a}$ \\
\hline EA_Pp_10768 & $\begin{array}{l}\text { Carnitine O-palmitoyltransferase I, mitochondrial liver isoform } \\
\text { (CPT I) (CPTI-L) (Carnitine) }\end{array}$ \\
\hline EA_Pp_14953 & $\begin{array}{l}\text { Casein kinase } 2 \text { alpha 2, mRNA (cDNA clone MGC:55229 } \\
\text { IMAGE:2600897), complete cds }\end{array}$ \\
\hline EA_Pp_12895 & Centrosomal protein $70 \mathrm{kDa}$ (Danio rerio) \\
\hline EA_Pp_12369 & CG6729-PA (Danio rerio) PREDICTED: similar to \\
\hline EA_Pp_11769 & Chloride channel 3 \\
\hline EA_Pp_13990 & Cholinergic receptor, nicotinic, alpha polypeptide 1 (Danio rerio) \\
\hline EA_Pp_11515 & Chromobox homologue 2 (drosophila Pc class) \\
\hline EA_Pp_11409 & Chromosome segregation 1-like \\
\hline EA_Pp_12673 & Complement C3-H1 [Cyprinus carpio] \\
\hline EA_Pp_10067 & Creatine kinase \\
\hline EA_Pp_14793 & $\begin{array}{l}\text { Cyclin-B }(\text { Danio rerio })>\text { gi }|20373137| \text { ref } \mid \text { NP_571588.1| cyclin B1 } \\
\quad \text { (Danio rerio })\end{array}$ \\
\hline EA_Pp_14453 & $\begin{array}{l}\text { Cyprinid microsatellite library MRB-2003 microsatellite Cyp-G1 } \\
\text { sequence }\end{array}$ \\
\hline EA_Pp_11642 & Cysteine-rich hydrophobic domain 2 \\
\hline EA_Pp_10085 & Cytochrome $\mathrm{P} 450$ aromatase $\mathrm{B}$ \\
\hline EA_Pp_11991 & Cytosolic alanine aminotransferase; cAAT; cGPT (Sparus aurata) \\
\hline EA_Pp_11703 & $\begin{array}{l}\text { DEAD/H (Asp-Glu-Ala-Asp/His) box polypeptide } 19 \text { (ddx19) } \\
\text { (DBP5 homologue, yeast) }\end{array}$ \\
\hline EA_Pp_12731 & $\begin{array}{l}\text { DEAD/H (Asp-Glu-Ala-Asp/His) box polypeptide } 26 \text { (Danio } \\
\text { rerio) PREDICTED: similar to }\end{array}$ \\
\hline
\end{tabular}


Appendix 6. Continued

\begin{tabular}{|c|c|}
\hline Probe ID & Gene name \\
\hline EA_Pp_11291 & Delta-6 fatty acyl desaturase (Cyprinus carpio) putative \\
\hline EA_Pp_10091 & Desmoglein 1 (DSG1), mRNA Homo sapiens \\
\hline EA_Pp_11825 & $\begin{array}{l}\text { Echinoderm microtubule associated protein like zgc: } 110445 \\
\text { hypothetical protein elongation factor 1-gamma (EF-1- } \\
\text { gamma) (eEF-1B gamma) > gi }|15528539| \text { dbj|BAB } 64568.1 \mid\end{array}$ \\
\hline EA_Pp_13325 & Elongation factor-1 gamma (Carassius auratus) \\
\hline EA_Pp_10144 & Oestrogen receptor alpha \\
\hline EA_Pp_10776 & Eukaryotic translation elongation factor 2 FHM_JGI.355.C1_-1 \\
\hline EA_Pp_12844 & $\begin{array}{l}\text { Eukaryotic translation initiation factor 2-alpha kinase } 3 \text { pre- } \\
\text { cursor (PRKR-like endoplasmic) }\end{array}$ \\
\hline EA_Pp_11894 & $\begin{array}{l}\text { Eukaryotic translation initiation factor } 5 \text { novel protein } \\
\quad \text { (zgc:77026) (Danio rerio) }\end{array}$ \\
\hline EA_Pp_14376 & F10 protein (Danio rerio) \\
\hline EA_Pp_14703 & $\begin{array}{l}\text { Fibroin-like substance-3 mRNA, complete cds Cyprinus carpio } \\
\text { ovarian }\end{array}$ \\
\hline EA_Pp_12938 & $\begin{array}{l}\text { Fibronectin type III and SPRY domain containing } 1 \text { isoform } 1 \\
\text { (Danio rerio) PREDICTED: }\end{array}$ \\
\hline EA_Pp_10158 & GAD 64 glutamic acid decarboxylase isoform 65 \\
\hline EA_Pp_13168 & $\begin{array}{l}\text { General transcription factor IIA, 1, 19/37 kDa (Danio rerio) } \\
\quad>\text { gi } 29124431|\mathrm{gb}| \text { AAH } 48894.1 \mid\end{array}$ \\
\hline EA_Pp_12759 & $\begin{array}{l}\text { Gigaxonin (Homo sapiens) > gi }|11545731| \mathrm{ref}\left|\mathrm{NP} \_071324.1\right| \text { giga- } \\
\quad \text { xonin (Homo sapiens) }\end{array}$ \\
\hline EA_Pp_11257 & GPI (glycophosphatidyl inositol)-anchored membrane protein 1 \\
\hline EA_Pp_12462 & $\begin{array}{l}\text { hi37 (Danio rerio) }>\text { gi }|50539670| \text { ref } \mid N_{-} \text {_001002300.1| hypotheti- } \\
\text { cal protein LOC } 336578\end{array}$ \\
\hline EA_Pp_14804 & $\begin{array}{l}\text { Histidyl-tRNA synthetase Zgc:92215 (Danio rerio) } \\
\quad>\text { gi|52219026|ref|NP_001004586.1| }\end{array}$ \\
\hline EA_Pp_12602 & 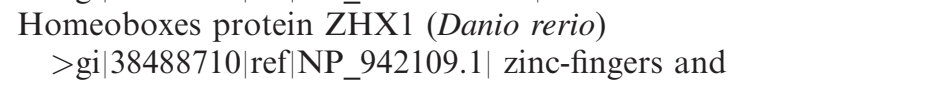 \\
\hline EA_Pp_12211 & $\begin{array}{l}\text { HSPC171 (similar to) hypothetical protein LOC404632 (Danio } \\
\text { rerio) }\end{array}$ \\
\hline EA_Pp_12624 & $\begin{array}{l}\text { Hydroxysteroid dehydrogenase like } 2 \text { (Danio rerio) } \\
>\text { gi }|41054573| \text { ref } \mid \text { NP_955893.1| }\end{array}$ \\
\hline EA_Pp_13556 & Hypothetical protein LOC550051 (Xenopus tropicalis) \\
\hline EA_Pp_12878 & $\begin{array}{l}\text { Hypothetical protein LOC74868 (Mus musculus) } \\
\quad>\text { gi } 66396509|\mathrm{gb}| \text { AAH96426.1| hypothetical }\end{array}$ \\
\hline EA_Pp_13920 & $\begin{array}{l}\text { Hypoxia up-regulated } 1 \text { Oxygen regulated protein }(150 \mathrm{kDa}) \\
(\text { Danio rerio })\end{array}$ \\
\hline EA_Pp_11503 & $\begin{array}{l}\text { Im:6901326 protein (Danio rerio) FHMinnow-GonadLib-1S4- } \\
\text { H09.g_-2 }\end{array}$ \\
\hline EA_Pp_14647 & Im:7150989 protein (Danio rerio) \\
\hline EA_Pp_12970 & IMP (inosine monophosphate) dehydrogenase 2 (Danio rerio) \\
\hline EA_Pp_14973 & $\begin{array}{l}\text { Influenza virus NS1A binding protein a, mRNA (cDNA clone } \\
\text { MGC:77050 IMAGE:6959874), }\end{array}$ \\
\hline EA_Pp_11427 & $\begin{array}{l}\text { Integrator complex subunit } 7 \text { (similar to) hypothetical protein } \\
\text { LOC286776 (Danio rerio) }\end{array}$ \\
\hline
\end{tabular}


Appendix 6. Continued

\begin{tabular}{|c|c|}
\hline Probe ID & Gene name \\
\hline EA_Pp_12027 & $\begin{array}{l}\text { Ionotropic N-methyl D-aspartate glutamate receptor } 1 \text { (GRIN1, } \\
\text { NR1, NMDAR1) (Danio rerio) }\end{array}$ \\
\hline EA_Pp_12816 & $\begin{array}{l}\text { Isocitrate dehydrogenase } 2 \text { (NADP+), mitochondrial (Danio } \\
\text { rerio) }\end{array}$ \\
\hline EA_Pp_13687 & $\begin{array}{l}\text { K123 protein (Danio rerio) PREDICTED: similar to } \\
\text { AIWA434.g1_-2 }\end{array}$ \\
\hline EA_Pp_14179 & $\begin{array}{l}\text { Kelch-like } 15 \text { (similar to) Zgc:101051 Danio rerio cDNA clone } \\
\text { MGC:101051 }\end{array}$ \\
\hline EA_Pp_13908 & $\begin{array}{l}\text { KIAA0188 (possibly similar to lipin) (Danio rerio) PREDICTED: } \\
\text { similar to }\end{array}$ \\
\hline EA_Pp_14364 & Kielin (Danio rerio) PREDICTED: similar to \\
\hline EA_Pp_11381 & $\begin{array}{l}\text { Kinesin-like protein KIF1C (Danio rerio) PREDICTED: hypo- } \\
\text { thetical protein XP_697372 [ }\end{array}$ \\
\hline EA_Pp_11752 & $\begin{array}{l}\text { Leucine rich repeat containing } 28 \text { (Danio rerio) PREDICTED: } \\
\text { similar to }\end{array}$ \\
\hline EA_Pp_13239 & LOC553488 protein (Danio rerio) \\
\hline EA_Pp_14318 & Matriptase (Danio rerio) PREDICTED: similar to \\
\hline EA_Pp_10796 & $\begin{array}{l}\text { Methionine adenosyltransferase } 2 \text { hypothetical protein } \\
\text { LOC541483 (Danio rerio) }\end{array}$ \\
\hline EA_Pp_14170 & $\begin{array}{l}\text { Methionine adenosyltransferase II, alpha, mRNA (cDNA clone } \\
\text { MGC:56664 }\end{array}$ \\
\hline EA_Pp_10313 & Mitochondrial uncoupling protein 2 (Leuciscus cephalus) \\
\hline EA_Pp_13675 & Myosin heavy chain (Cyprinus carpio) \\
\hline EA_Pp_14166 & $\begin{array}{l}\text { Myosin regulatory light chain, complete cds, clone:pLC2 10-2 } \\
\text { Cyprinus carpio mRNA for }\end{array}$ \\
\hline EA_Pp_10771 & $\begin{array}{l}\text { NADH dehydrogenase subunit } 5 \text { (Sarcocheilichthys variegatus } \\
\text { microoculus) }\end{array}$ \\
\hline EA_Pp_14615 & Nuclear receptor coactivator 4 (Danio rerio) Similar to \\
\hline EA_Pp_12907 & Parvalbumin (Cyprinus carpio) FHM_JGI.62.C8_-1 \\
\hline EA_Pp_10234 & $\begin{array}{l}\text { Peroxisome proliferator activated receptor isoform b (Pimephales } \\
\text { promelas) }\end{array}$ \\
\hline EA_Pp_11726 & $\begin{array}{l}\text { Phosphatase and tensin-like protein A long splice variant (Danio } \\
\text { rerio) }\end{array}$ \\
\hline EA_Pp_12253 & $\begin{array}{l}\text { Phosphoglucomutase } 2 \text { hypothetical protein LOC405822 (Danio } \\
\text { rerio) }\end{array}$ \\
\hline EA_Pp_13858 & Pim1 protein (Danio rerio) \\
\hline EA_Pp_12681 & $\begin{array}{l}\text { Pleckstrin homology domain containing, family M (with RUN } \\
\text { domain) member } 1 \text { (Danio rerio) }\end{array}$ \\
\hline EA_Pp_12259 & $\begin{array}{l}\text { Pleckstrin homology domain containing KIAA1686 protein } \\
\text { (Danio rerio) PREDICTED: similar }\end{array}$ \\
\hline EA_Pp_12050 & $\begin{array}{l}\text { Potassium channel tetramerization domain containing } 6 \text { hypo- } \\
\text { thetical protein LOC436601 }\end{array}$ \\
\hline EA_Pp_14205 & $\begin{array}{l}\text { Potassium inwardly-rectifying channel, subfamily J, member } 1 \\
\text { (Danio rerio) PREDICTED: }\end{array}$ \\
\hline EA_Pp_14157 & PREDICTED: similar to CG5020-PA, isoform A (Danio rerio) \\
\hline EA_Pp_14824 & $\begin{array}{l}\text { PREDICTED: similar to CG6406-PB, isoform B, partial (Danio } \\
\text { rerio) }\end{array}$ \\
\hline
\end{tabular}


Appendix 6. Continued

\begin{tabular}{|c|c|}
\hline Probe ID & Gene name \\
\hline EA_Pp_14427 & $\begin{array}{l}\text { PREDICTED: similar to RIKEN cDNA 1110032A13 isoform } 2 \\
\text { (Danio rerio) }\end{array}$ \\
\hline EA_Pp_13629 & $\begin{array}{l}\text { Preprohepcidin (Danio rerio) }>\text { gi }|38351815| \mathrm{gb}|\mathrm{AAR} 18592.1| \\
\text { preprohepcidin } 1 \text { (Danio rerio) }\end{array}$ \\
\hline EA_Pp_10237 & $\begin{array}{l}\text { Presenilin-1 (Danio rerio) } \\
>\text { gi }|37082580| \text { sp } \mid \text { Q9W6T7|PSN1_BRARE Presenilin-1 (PS1) } \\
\text { (Zf- }\end{array}$ \\
\hline EA_Pp_10725 & Prosaposin (Danio rerio) \\
\hline EA_Pp_11294 & Protein disulfide isomerase-associated 4 (Danio rerio) \\
\hline EA_Pp_14241 & $\begin{array}{l}\text { Protein disulfide isomerase-related protein (provisional), mRNA } \\
\text { (cDNA clone MGC:55846) }\end{array}$ \\
\hline EA_Pp_13213 & $\begin{array}{l}\text { Protein transport protein Sec24D (SEC24-related protein D) } \\
\text { (Danio rerio) PREDICTED: }\end{array}$ \\
\hline EA_Pp_10241 & $\begin{array}{l}\text { Rap1ga1 protein (Rap1 GTPase activating protein) (Danio rerio) } \\
\text { PREDICTED: similar to }\end{array}$ \\
\hline EA_Pp_14934 & Regulator of G-protein signaling 9 (RGS9) (Danio rerio) \\
\hline EA_Pp_10969 & $\begin{array}{l}\text { Ribosomal protein L21 (Danio rerio) } \\
\quad>\text { gi }|68404101| \text { ref } \mid \text { XP_689959.1| PREDICTED: similar to }\end{array}$ \\
\hline EA_Pp_11861 & RNF141 protein (Danio rerio) \\
\hline EA_Pp_15100 & Rpl17 protein (Mus musculus) \\
\hline EA_Pp_13265 & $\begin{array}{l}\text { Sarcoglycan delta (Danio rerio) } \\
\quad>\text { gi }|49227301| \text { ref } \mid \text { NP_001001816.1| sarcoglycan, delta }\end{array}$ \\
\hline EA_Pp_13216 & $\begin{array}{l}\text { SH2 domain containing } 4 \mathrm{~A} \text { (Gallus gallus) PREDICTED: similar } \\
\text { to }\end{array}$ \\
\hline EA_Pp_13267 & $\begin{array}{l}\text { Ski-interacting protein (Danio rerio) } \\
\quad>\text { gi }|50838798| \operatorname{ref} \mid \text { NP_001002864.1| SKI interacting }\end{array}$ \\
\hline EA_Pp_12496 & $\begin{array}{l}\text { Solute carrier family } 25 \text { (mitochondrial carrier; phosphate } \\
\text { carrier), member } 23 \text { (Danio rerio) }\end{array}$ \\
\hline EA_Pp_10833 & $\begin{array}{l}\text { Solute carrier family } 38 \text {, member } 4 \text { (SLC38A4) (Danio rerio) } \\
\text { novel protein similar to vertebrate }\end{array}$ \\
\hline EA_Pp_11949 & $\begin{array}{l}\text { Sperm associated antigen } 6 \text { hypothetical protein LOC } 431757 \\
\text { (Danio rerio) }\end{array}$ \\
\hline EA_Pp_14735 & $\begin{array}{l}\text { Structure specific recognition protein 1, mRNA (cDNA clone } \\
\text { MGC:66086 IMAGE:6797288), }\end{array}$ \\
\hline EA_Pp_11636 & Sulphatase FP1c, partial (Danio rerio) \\
\hline EA_Pp_12001 & $\begin{array}{l}\text { SWI/SNF-related matrix-associated actin-dependent regulator of } \\
\text { chromatin a-like } 1 \text {; HepA- }\end{array}$ \\
\hline EA_Pp_12513 & $\begin{array}{l}\text { Synapse-associated protein } 1 \text { (Danio rerio) } \\
\quad>\text { gi }|41055612| \text { ref } \mid \text { NP_957236.1| synapse }\end{array}$ \\
\hline EA_Pp_14774 & $\begin{array}{l}\text { Synaptonemal complex protein } 3 \text { PREDICTED: similar to } \\
\text { (Danio rerio) }\end{array}$ \\
\hline EA_Pp_14006 & Synaptopodin 2-like (Danio rerio) \\
\hline EA_Pp_13948 & Synaptotagmin-like protein 2 -a delta $2 \mathrm{~S}-\mathrm{I}$ (Danio rerio) \\
\hline EA_Pp_11559 & $\begin{array}{l}\text { Tetratricopeptide repeat domain } 15 \text { (Danio rerio) PREDICTED: } \\
\text { similar to }\end{array}$ \\
\hline EA_Pp_13391 & Transmembrane protein-precursor (Danio rerio) \\
\hline
\end{tabular}


Appendix 6. Continued

\begin{tabular}{|c|c|}
\hline Probe ID & Gene name \\
\hline EA_Pp_13583 & $\begin{array}{l}\text { Tubulin, alpha } 4 \text { like (Danio rerio). Unknown (protein for } \\
\text { MGC:55727) (Danio rerio) }\end{array}$ \\
\hline EA_Pp_11476 & Ubiquitin C (Homo sapiens) \\
\hline EA_Pp_12468 & Unknown (Danio rerio) \\
\hline EA_Pp_13121 & Vacuolar protein sorting $4 \mathrm{~b}$ Vps4b-prov protein (Xenopus laevis) \\
\hline EA_Pp_11182 & $\begin{array}{l}\text { Vigilin high density lipoprotein-binding protein (vigilin) (Danio } \\
\text { rerio) }\end{array}$ \\
\hline EA_Pp_11623 & $\begin{array}{l}\text { Vitamin K epoxide reductase complex, subunit 1-like hypothet- } \\
\text { ical protein LOC } 553717\end{array}$ \\
\hline EA_Pp_15083 & $\begin{array}{l}\text { WD repeat domain } 34 \text { isoform } 1 \text { (Danio rerio) PREDICTED: } \\
\text { similar to }\end{array}$ \\
\hline EA_Pp_13881 & $\begin{array}{l}\text { x-box binding protein 1B Xbp1 protein (Danio rerio) } \\
\quad>\text { gi }|18419453| \mathrm{gb} \mid \text { AAL69333.1| (Danio rerio) }\end{array}$ \\
\hline EA_Pp_14699 & XP_677890 isoform 1 (Danio rerio) \\
\hline EA_Pp_11650 & $\begin{array}{l}\text { X-prolyl aminopeptidase (aminopeptidase P) 1, soluble (Danio } \\
\text { rerio) }\end{array}$ \\
\hline EA_Pp_14584 & $\begin{array}{l}\text { Zebrafish DNA sequence from clone } \mathrm{CH} 211-119 \mathrm{H} 23 \text { in linkage } \\
\text { group 2, complete sequence }\end{array}$ \\
\hline EA_Pp_14140 & $\begin{array}{l}\text { Zebrafish DNA sequence from clone CH211-138G9 in linkage } \\
\text { group 20, complete sequence }\end{array}$ \\
\hline EA_Pp_14349 & $\begin{array}{l}\text { Zebrafish DNA sequence from clone DKEY-15F17, complete } \\
\text { sequence }\end{array}$ \\
\hline EA_Pp_14016 & $\begin{array}{l}\text { Zebrafish DNA sequence from clone DKEY-170H8 in linkage } \\
\text { group 7, complete sequence }\end{array}$ \\
\hline EA_Pp_14095 & $\begin{array}{l}\text { Zebrafish DNA sequence from clone DKEY-253A1 in linkage } \\
\text { group 9, complete sequence }\end{array}$ \\
\hline EA_Pp_15101 & $\begin{array}{l}\text { Zebrafish DNA sequence from clone DKEY-81P7, complete } \\
\text { sequence }\end{array}$ \\
\hline EA_Pp_14724 & $\begin{array}{l}\text { Zebrafish DNA sequence from clone DKEY-90M5 in linkage } \\
\text { group 20, complete sequence }\end{array}$ \\
\hline EA_Pp_14186 & $\begin{array}{l}\text { Zgc: } 103404 \text { (Danio rerio) > gi|54400596|ref|NP_001006047.1| } \\
\text { hypothetical protein }\end{array}$ \\
\hline EA_Pp_11569 & $\begin{array}{l}\text { Zgc:110112 hypothetical protein LOC550237 (Danio rerio) } \\
\quad>\text { gi }|62204278| \mathrm{gb} \mid \text { AAH } 92736.1 \mid\end{array}$ \\
\hline EA_Pp_10120 & $\begin{array}{l}\text { Zgc: } 113320 \text { hypothetical protein LOC550609 (Danio rerio) } \\
\quad>\text { gi }|62185659| \mathrm{gb} \mid \text { AAH } 92365.1 \mid\end{array}$ \\
\hline EA_Pp_12720 & $\begin{array}{l}\text { Zgc: } 123187 \text { major facilitator superfamily domain containing } \\
\text { hypothetical protein }\end{array}$ \\
\hline EA_Pp_11539 & $\begin{array}{l}\text { Zgc:55549 hypothetical protein MGC55549 (Danio rerio) } \\
\quad>\text { gi| } 41056171 \mid \text { ref|NP_956624.1| }\end{array}$ \\
\hline EA_Pp_14261 & Zgc:56141 (zgc:56141), mRNA Danio rerio \\
\hline EA_Pp_11749 & $\begin{array}{l}\text { Zinc finger, RAN-binding domain containing } 1 \text { (Danio rerio) } \\
\text { PREDICTED: similar to }\end{array}$ \\
\hline EA_Pp_11935 & $\begin{array}{l}\text { Zona pellucida-like domain novel protein containing a } \\
\text { (wu:fi27h02) (Danio rerio) }\end{array}$ \\
\hline EA_Pp_11682 & ZP2, partial (Danio rerio) PREDICTED: similar to \\
\hline
\end{tabular}

${ }^{a} t$-test $P$-value for a single probe $<0 \cdot 05$, no conflicting fold change data for duplicate or multiple probes. 